\title{
$\mathrm{C}|\mathrm{E}| \mathrm{D}|\mathrm{L}| \mathrm{A} \mid \mathrm{S}$
}

Centro de Estudios

Distributivos, Laborales y Sociales

Maestría en Economía

Universidad Nacional de La Plata

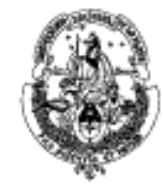

\section{Property Rights for the Poor: Effects of Land Titling}

\section{Sebastian Galiani y Ernesto Schargrodsky}

Documento de Trabajo Nro. 103

Agosto, 2010

ISSN 1853-0168 


\title{
Property Rights for the Poor: Effects of Land Titling
}

\author{
Sebastian Galiani \\ Washington University in St Louis \\ Ernesto Schargrodsky* \\ Universidad Torcuato Di Tella
}

January 28,2010

\begin{abstract}
Secure property rights are considered a key determinant of economic development. The evaluation of the causal effects of property rights, however, is a difficult task as their allocation is typically endogenous. To overcome this identification problem, we exploit a natural experiment in the allocation of land titles. In 1981, squatters occupied a piece of land in a poor suburban area of Buenos Aires. In 1984, a law was passed expropriating the former owners' land to entitle the occupants. Some original owners accepted the government compensation, while others disputed the compensation payment in the slow Argentine courts. These different decisions by the former owners generated an exogenous allocation of property rights across squatters. Using data from two surveys performed in 2003 and 2007, we find that entitled families substantially increased housing investment, reduced household size, and enhanced the education of their children relative to the control group. These effects, however, did not take place through improvements in access to credit. Our results suggest that land titling can be an important tool for poverty reduction, albeit not through the shortcut of credit access, but through the slow channel of increased physical and human capital investment, which should help to reduce poverty in the future generations.
\end{abstract}

JEL: P14, Q15, O16, J13

Keywords: Property rights, land titling, natural experiment, urban poverty.

\footnotetext{
* Sebastian Galiani, Department of Economics, Washington University in St Louis, Campus Box 1208, St Louis, MO 63130-4899, US, galiani@wustl.edu. Ernesto Schargrodsky, Universidad Torcuato Di Tella, Saenz Valiente 1010, (C1428BIJ) Buenos Aires, Argentina, eschargr@utdt.edu. We are grateful to seminar participants at the AEA meetings, NBER, Harvard, MIT, Stanford, Chicago, Yale, Berkeley, Columbia, UCLA, UCL, UC San Diego, Brown, Boston University, Washington in St. Louis, Essex, Miami, Econometric Society, ISNIE, Ronald Coase Institute, LACEA, NIP, Universidad de Chile, Universidad Getulio Vargas, PUC Rio, Universidad de Montevideo, UdeSA, UTDT, World Bank, and IADB for helpful comments. Alberto Farias and Daniel Galizzi provided crucial help throughout this study. We also thank Gestion Urbana -the NGO that performed the survey-, Eduardo Amadeo, Julio Aramayo, Rosalia Cortes, Maria de la Paz Dessy, Pedro Diaz, Alejandro Lastra, Hector Lucas, Graciela Montañez, Juan Sourrouille, and Ricardo Szelagowski for their cooperation; Matias Cattaneo, Sebastian Calonico and Florencia Borrescio Higa for excellent research assistance; the World Bank and the Inter-American Development Bank for financial support for our 2003 survey, and the Ronald Coase Institute for financial support for our 2007 survey.
} 


\section{Introduction}

The fragility of property rights is considered a crucial obstacle for economic development (North and Thomas, 1973; North, 1981; De Long and Shleifer, 1993; Acemoglu, Johnson, and Robinson, 2001; Johnson, McMillan and Woodruff, 2002; inter alia). The main argument is that individuals underinvest if others can seize the fruits of their investments (Demsetz, 1967; Alchian and Demsetz, 1973). In today's developing world, a pervasive manifestation of feeble property rights are the millions of people living in urban dwellings without possessing formal titles of the plots of land they occupy (Deininger, 2003; and Banerjee and Duflo, 2006). The absence of formal property rights constitutes a severe limitation for the poor. In addition to its investment effects, the lack of formal titles impedes the use of land as collateral to access the credit markets (Feder et al., 1988). It also affects the transferability of the parcels (Besley, 1995), making investments in untitled parcels highly illiquid. Moreover, the absence of formal titles deprives poor families of the possibility of having a valuable insurance and savings tool that could provide protection during bad times and retirement, forcing them instead to rely on extended family members and offspring as insurance mechanisms.

Land-titling programs have been recently advocated in policy circles as a powerful intervention to rapidly reduce poverty. De Soto (2000) emphasizes that the lack of property rights impedes the transformation of the wealth owned by the poor into capital. Proper titling could allow the poor to collateralize the land. In turn, this credit could be invested as capital in productive projects, promptly increasing labor productivity and income. Inspired by these ideas, and fostered by international development agencies, land-titling programs have been launched throughout developing and transition economies as part of poverty alleviation efforts.

In this paper, we investigate the effects of issuing land titles to a very deprived population. The identification of land-titling effects, however, is a difficult task because it typically faces the problem that formal property rights are endogenous. The allocation of property rights across households is usually not random but based on wealth, family characteristics, individual effort, previous investment levels, or other mechanisms built on differences between the groups that acquire those rights and the groups that do not. We address this selection problem exploiting a natural experiment that provides us with 
a source of variability in the allocation of property rights that is exogenous to the squatter and parcel characteristics.

In 1981, a group of squatters occupied an area of wasteland in the outskirts of Buenos Aires, Argentina. The area was composed of different tracts of land, each with a different legal owner. An expropriation law was subsequently passed, ordering the transfer of the land from the original owners to the state in exchange for a monetary compensation, with the purpose of entitling it to the squatters. However, only some of the original legal owners surrendered the land. The parcels located on the ceded tracts were transferred to the squatters with legal titles that secured the property of the parcels. Other original owners, instead, are still disputing the government compensation in the slow Argentine courts. As a result, a group of squatters obtained formal land rights, while others are currently living in the occupied parcels without paying rent, but without legal titles. Both groups share the same household pre-treatment characteristics. Moreover, they live next to each other, and the parcels they inhabit are identical. Since the decision of the original owners of accepting or disputing the expropriation payment was orthogonal to the squatter characteristics, the allocation of property rights is exogenous in equations describing the behavior of the occupants. Thus, this natural experiment provides a control group that estimates what would have happened to the treated group in the absence of the intervention, allowing us to identify the causal effects of land titling.

Exploiting this natural experiment, we find significant effects on housing investment, household size, and child education. The constructed surface increases by $12 \%$, while an overall index of housing quality rises by $37 \%$. Moreover, households in the titled parcels have a smaller size (an average of 5.11 members relative to 6.06 in the untitled group), both through a diminished presence of extended family members and a reduced fertility of the household heads. In addition, the children from the households that reduced fertility show significantly better educational achievement, with an average of 0.69 more years of schooling and twice the completion rate of secondary education (53\% vs. $26 \%$ ). However, we only find modest effects on access to credit markets as a result of entitlement, and no improvement in labor market performance of the household heads. 
Several studies have documented the effects of land property rights and titling programs on different variables. A partial listing includes Jimenez (1984), Alston et al. (1996) and Lanjouw and Levy (2002) on real estate values; Besley (1995), Brasselle et al. (2002), Field (2005), and Do and lyer (2008) on investment; Banerjee et al. (2002) and Libecap and Lueck (2008) on agricultural productivity, Field (2007) on labor supply; Feder et al. (1988), Place and Migot-Adholla (1998), Carter and Olinto (2002), Field and Torero (2003) on access to credit, and Di Tella, Galiani and Schargrodsky (2007) on the formation of beliefs. Our strong results on investment and our weak results on access to credit coincide with the findings of this preceding literature. To the best of our knowledge, the causal effects of land titling on household structure and educational achievement had not been previously analyzed.

Our results suggest that land titling can be an important tool for poverty reduction, albeit not through the shortcut of credit access and entrepreneurial income, but through the slow channel of increased physical and human capital investment.

The rest of the paper is organized as follows. In the next section we describe the natural experiment. Section III describes our data, and section IV discusses the identification methods. Section $V$ presents our empirical results, while section VI concludes.

\section{A Natural Experiment}

The empirical evaluation of the effects of land titling poses a major methodological challenge. The allocation of property rights across families is typically not random but based on wealth, family characteristics, individual effort, previous investment levels, or other selective mechanisms. Thus, the individual characteristics that determine the likelihood of receiving land titles are probably correlated with the outcomes under study. Since some of these personal characteristics are unobservable, this correlation creates a selection problem that obstructs the proper evaluation of the effects of property right acquisition.

In this paper, we address this selection problem by exploiting a natural experiment in the allocation of property rights. In 1981, about 1,800 families occupied a piece of wasteland in San Francisco Solano, County of Quilmes, in the Province of Buenos Aires, Argentina. 
The occupants were groups of landless citizens organized through a Catholic chapel. As they wanted to avoid creating a shantytown, they partitioned the occupied land into small urban-shaped parcels. At the beginning of the occupation the squatters believed that the land belonged to the state, but it was actually private property. ${ }^{1}$ The occupants resisted several attempts of eviction during the military government. After Argentina's return to democracy, the Congress of the Province of Buenos Aires passed Law N 10.239 in 1984 expropriating these lands from the former owners to allocate them to the squatters.

Figure 1 presents a timeline of the events in our study.

Figure 1 - Timeline of Events

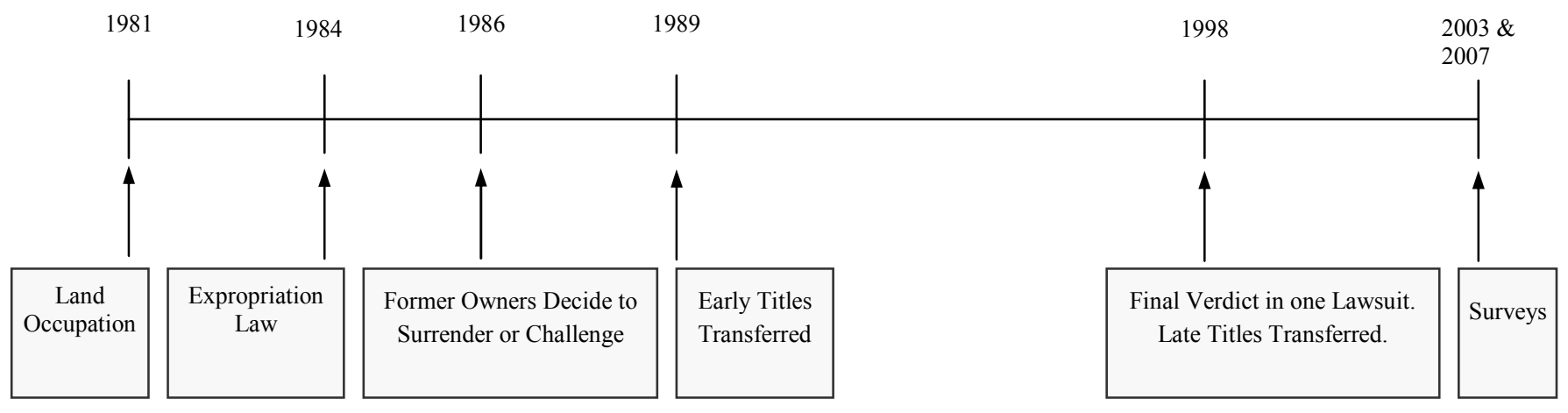

According to the expropriation law, the government would pay a monetary compensation to the former owners and it would then allocate the land to the squatters. In order to qualify for receiving the titles, the squatters should have arrived to the parcels at least one year before the sanctioning of the law, should not possess any other property, and should use the parcel as their family home. Within each household, the titles would be awarded to both the household head identified at that time and to her/his spouse (if

\footnotetext{
1 This is explained by the squatters in the documentary movie "Por una tierra nuestra" by Cespedes (1984). On the details of the land occupation process also see Briante (1982), CEUR (1984), Izaguirre and Aristizabal (1988), and Fara (1989). Information on the land expropriation process was obtained from the Land Secretary of the Province of Buenos Aires, the office of the General Attorney of the Province of Buenos Aires, the Quilmes County Government, the Land Registry, and the judicial cases. Additional information presented in this section was gathered through a series of interviews with key informants, including the Secretary of Land of the Province of Buenos Aires (Maria de la Paz Dessy), Undersecretary of Land of the Province of Buenos Aires (Alberto Farias), Directors of Land of Quilmes County (Daniel Galizzi and Alejandro Lastra), Secretary of Public Works and Land Registry of Quilmes County (Hector Lucas), General Attorney of the Province of Buenos Aires (Ricardo Szelagowski), attorney in expropriation offers' office (Claudio Alonso), lawyer on expropriation lawsuit (Horacio Castillo), former land owners (Hugo Spivak and Alejandro Bloise -heir-), squatters (Juan Carlos Sanchez and Jorge Valle, inter alia), and President of NGO Gestion Urbana (Estela Gutierrez).
} 
married or cohabitating). The law also established that the squatters could not transfer the property of the parcels for the first ten years after titling.

The process of expropriation resulted to be asynchronous and incomplete. The occupied area turned out to be composed of thirteen tracts of land belonging to different owners. In 1986, the government offered each owner (or group of co-owners, as several tracts of land had more than one owner) a payment proportional to the official valuation of each tract of land, indexed by inflation. These official valuations, assessed by the tax authority to calculate property taxes, had been set before the land occupation. After the government made the compensation offers, the owner/s of each tract had to decide whether to surrender the land (accepting the expropriation compensation) or to start a legal dispute. Eight former owners accepted the compensation offered by the government. Five former owners, instead, did not accept the government offer and filed charges with the aim of obtaining a higher compensation. In 1989, the tracts of land of the former owners that accepted the government compensation were transferred to the squatters occupying them, together with formal land titles that secured the property of the parcels. ${ }^{2}$ The squatters that received titles in 1989 constitute the early-treated group in our study. ${ }^{3}$

\footnotetext{
2 The "new" urban design traced by the squatters differed from the previous land tract divisions. Thus, some "new" parcels overlapped over tracts of land that belonged to more than one former owner. This could be interpreted as further evidence of the squatters' ignorance about the previous land ownership status. Had they known the existence of different private owners, they should have followed the previous land design to avoid being exposed to the decisions of two or three landowners rather than one. For regulatory reasons, parcels could not be delimited and titled if one portion of them was still under dispute.

${ }^{3}$ The market value of land parcels comparable to the ones titled to the squatters amounted to approximately 7.4 times the monthly average total household income for the first quintile of the official household survey (EPH) of October 1986 for the Buenos Aires metropolitan area (market value of parcels in the neighboring non-squatted area obtained from evidence presented in "Kraayenbrink de Beurts et al. v. Province of Buenos Aires"). This figure, however, constitutes only an upper bound of the differential wealth transfer received by the entitled households for three reasons. First, the expropriation law established that each titled squatter had to pay the government the proportionally prorated share of the official valuation of the occupied tract of land. The law, however, established that the payments should be made in monthly installments that could never surpass $10 \%$ of the (observable) household income and there was no indexation for inflation. Given the hyperinflationary periods experienced by the Argentine economy during the period of analysis and the high labor informality of this population, the real values paid by the squatters were probably quite small. In practice, there are no records of the amounts and dates of the payments made by each household. Second, entitled households are supposed to regularly pay property taxes. Third, untitled squatters pay no rent.
} 
The people who occupied parcels located on the tracts of land that belonged to the former owners that accepted the expropriation compensation, were ex-ante similar, and arrived at the same time, than the people who settled on the tracts of the former owners that did not surrender the land. There was simply no way for the occupants to know exante, at the time of the occupation, which parcels of land had owners who would accept the compensation and which parcels had owners who would dispute it. In fact, at the time of the occupation the squatters believed that all the land was state-owned and they could not know that an expropriation law was going to be passed, nor what was going to be the future response of the owner of each specific parcel.

A potential concern, however, is that the different former owners' decisions could reflect differences in land quality. In turn, these differences could be correlated with squatters' heterogeneity. For example, more powerful squatters could have settled in the best parcels. An advantage of our experiment is that the parcels of land in the treatment (titled) and control (untitled) groups are almost identical and basically next to each other. Indeed, after the data description, we show in Section IV that there are no differences in observable parcel characteristics (distance to a polluted creek, distance to the closest non-squatted area, parcel size, location in a corner of a block) between the treatment and control groups. ${ }^{4}$ We also show that there are no differences in pre-treatment observable household characteristics (age, gender, nationality and years of education of the person who was the household head at the time of the occupation, and nationality and years of education of her/his parents). Importantly, all the evidence on the occupation process (the documentary movie, the articles, the judicial files, and the interviews with squatters, lawyers and former owners described in footnote 1) coincide that the squatters had no direct contact with the former owners to influence their decisions. Moreover, the dwellings constructed by the squatters had to be explicitly ignored in the calculation of the expropriation compensation, and the government offers were very similar (in per-square-meter terms) for the accepting and contesting owners, in accordance with the proximity and alikeness of the land tracts. ${ }^{5}$

\footnotetext{
${ }^{4}$ There are also no differences in altitude. The Buenos Aires metropolitan area is totally flat and all these parcels are within the same 5-meter topographical range. Besides, as this is urban land, agricultural productivity is not an issue.

5 In Argentine pesos (of January 1986) per square meter, the accepted offers had a mean of 0.424 and a median of 0.391 . The contested offers had a mean of 0.453 and a median of 0.397 . Indeed, the similitude of the offers is repeatedly used as an argument by the government attorneys in the expropriation lawsuits to demonstrate that the government offers were fair, as
} 
Given the similarity in land quality and compensation offers, the different responses might instead reflect heterogeneity of the former owners regarding decision-making, subjective land value, or litigation costs. Although thirteen tracts of land provide a small number for a statistical analysis, a few patterns emerge. The average number of coowners in the groups of accepting owners is 1.25 , while the average number of coowners for the contested tracts is 2.2. Moreover, when we defined a dummy equal to 1 if there is more than one co-owner sharing the same family name, and 0 otherwise, the average for this dummy for the accepting owners is 0.125 while the average for the challenging owners is 0.6 . Thus, it appears that having many co-owners and several in the same family made it more difficult for the owners to agree on accepting the government offer. ${ }^{6}$ Note that if, in spite of this discussion, one may still fear that the challenging owners did so because the unobservable quality of their land was higher, that would imply that the squatters that did not receive titles are standing on land of better quality.

As explained, five former owners did not accept the compensation offered by the government and went to trial. In these lawsuits, all the legal discussion hinges around the determination of the monetary compensation. The Congress constitutionally approved the law and, thus, the expropriation itself could not be challenged. The squatters had no participation in these legal processes (the lawsuits were exclusively between the former owners and the provincial government), and the value of the dwellings they constructed was explicitly excluded from the dispute over the monetary compensation ("Cordar SRL v. Province of Buenos Aires"). One of these five lawsuits ultimately ended with a final verdict, and the squatters on this tract of land received titles in 1998 (the late treated). The other four lawsuits are still pending in the slow Argentine courts. If one is still worried about the possibility that the former owners' decisions of

\footnotetext{
they were similar to the ones accepted by other owners. The same argument is utilized in a lowcourt verdict in "Kraayenbrink de Beurts et al. v. Province of Buenos Aires" citing jurisprudence of the Supreme Court.

${ }^{6}$ Kaplan et al. (2006) find that cases are less likely to be settled (more likely to go to court) when they involve multiple plaintiffs. See also Fiss (1984). On family economic decisions see, for example, Burkart et al. (2003) and Bennedsen et al. (2007). Within the challenging owners, we also found one case in which an owner was a lawyer who was representing himself in the case (which may suggest lower litigation costs), while in another case, one of the original owners had passed away before the sanctioning of the law but her inheritance process was still under way at the time the family had to make a decision.
} 
surrendering or suing was correlated with land quality or squatters' characteristics, then an additional feature of this experience is that it allows us to separately compare the squatters in this late-treated group relative to the control group. Although these two groups of squatters settled in tracts of land which are homogenous regarding their respective former owners' decisions of going to trial, one group already received titles while the other is still waiting for the end of the legal processes. ${ }^{7}$

The final outcome of this expropriation process is that a group of families now has legal property rights, while another group is still living in the occupied parcels enjoying free usufructuary rights but without possessing formal land titles. This allocation of land titles was the result of an expropriation process that did not depend on any particular characteristic of the squatters nor of the parcels of land they occupied. Thus, by comparing the groups that received and did not receive land titles, we can act as if we have a randomized experiment.

\section{Data Collection}

The area affected by Expropriation Law No 10.239 covers a total of 1,839 parcels. 1,082 of these parcels are located in a contiguous set of blocks. However, the law also included another non-contiguous (but close) piece of land currently called San Martin neighborhood, which comprises 757 parcels. As this area is physically separated from the rest, we focus on the 1,082 contiguous parcels to improve comparability.

We have precise knowledge of the titling status of each parcel. Land titles were awarded in two phases. Property titles were awarded to the occupants of 419 parcels in 1989 , and to the occupants of 173 parcels in 1998. Land titles are not available to the families living in 410 parcels located on tracts of land that have not been surrendered to the government in the expropriation process. Finally, there are 80 parcels that were not titled because the squatters occupying them had not fulfilled some of the required registration

\footnotetext{
${ }^{7}$ We can still wonder, within this group of former owners that disputed the compensation, why some are still on trial while one concluded. Exogenous reasons lengthened the pending trials. In two cases, the expropriation lawsuit was delayed by the death of one of the former owners, which required an inheritance process. In another case (mentioned in footnote 6 ) one of the original owners had died just before the sanctioning of the law and her inheritance process had not finished. In the fourth case, the legal process was delayed by a mistake made in the description of the land tract in a low-court judge's verdict.
} 
steps, or had moved or died at the time of the title offers, although the original owners had surrendered these pieces of land to the government. This subgroup constitutes the "non-compliers" in our study, since they were offered the treatment (land title) but they did not receive it. ${ }^{8}$

Two surveys performed in 2003 and 2007 provide the data utilized for this study. In 2003 , the inhabitants of 590 randomly selected parcels (out of the total of 1,839 ) were interviewed. 617 households living in these 590 parcels (27 parcels host more than one family) were surveyed. Excluding the non-contiguous San Martin neighborhood, we interviewed 467 households living in 448 parcels. The questionnaire covered socioeconomic variables including household structure, labor market outcomes, and credit information. At the same time, we sent a team of architects to measure housing investments by performing an outside evaluation of the characteristics of the dwellings in all the parcels. ${ }^{9}$

The 245 families in the contiguous area that were identified in the 2003 survey as having arrived to the current parcels before the treatment assignment (see next section) and as having offspring of the household head of 0-16 years of age, were the target of the 2007 survey. This second survey aimed to measure the school achievement of the sample of 701 children satisfying these conditions (who by then were between 4-20 years old) as they progressed throughout the educational system. 217 of these 245 households (633 of these 701 children) were successfully re-interviewed. ${ }^{10}$

\footnotetext{
${ }^{8} 23$ of these 80 parcels could have been titled in 1989, while the other 57 correspond to the group titled in 1998. The 757 parcels of San Martin, which belonged to an owner who accepted the expropriation compensation without suing, were offered for titling in 1991.712 were titled, while 45 correspond to non-compliers.

${ }^{9}$ Gestion Urbana, an NGO that works in this area, carried out the household survey and the housing evaluation. We distributed food stamps for each answered survey as a token of gratitude to the families willing to participate in our study. In 10 percent of the cases, the survey could not be performed because there was nobody at home in three visit attempts, the parcel was not used as a house, rejection, or other reasons. These parcels were randomly replaced. Non-response rates were similar for titled and untitled parcels.

${ }^{10}$ The NGO Gestion Urbana also conducted the education survey, distributing again food stamps for each answered survey. Re-interviewing was greatly facilitated by our collection of exact name, date of birth, national ID number, address, and parents' given names for the offspring of the household heads in the first survey. Re-interview rates were similar for titled and untitled parcels. When a family had moved from their 2003 location, surveyors attempted to find the target family using the 2003 data and the information provided by the current occupants. 7 of the 217 families were interviewed in this way.
} 


\section{Identification Strategy}

We seek to identify the effect of the allocation of property rights on several outcome variables exploiting a natural experiment in the allocation of land titling. In a natural experiment, like in a randomized trial, there is a control group that estimates what would have happened to the treated group in the absence of the intervention, but nature or other exogenous forces determine treatment status instead. The validity of the control group is evaluated by examining the exogeneity of treatment status with respect to the potential outcomes, and by testing that the pre-intervention characteristics of the treatment and control groups are reasonably similar. In section II we discussed at length the process of allocation of land title offers and argued that this process was exogenous to the characteristics of the squatters in our experiment. We now test the similarity of pre-treatment characteristics between the treatment and control groups.

In Table 1, we compare pre-treatment characteristics for the non-intention-to-treat and intention-to-treat groups to analyze the presence of potential differences. The variable Property Right Offer equals 1 for the parcels that were surrendered by the original owners, and 0 otherwise. In Panel A, we compare parcel characteristics: distance to a nearby (polluted and floodable) creek, distance to the closest non-squatted area, parcel size, and a dummy for whether the parcel is located in a corner of a block. We only reject the hypotheses of equality for parcel size (at the $8.9 \%$ level of significance). Nevertheless, the difference in average parcel sizes between these two groups is relatively small -parcels are only $3 \%$ larger in the non-intention-to-treat group- and if something, it is the control group the one that inhabits slightly larger parcels.

In Panel B of Table 1, we compare pre-treatment characteristics of the "original squatter" between the non-intention-to-treat and intention-to-treat groups for the families that arrived before treatment. We define the "original squatter" as the household head at the time the family arrived to the parcel they are currently occupying. We cannot reject the hypotheses of equality in age, gender, nationality and years of education of the original squatter, suggesting a strong similarity between these groups at the time of their arrival to this area. Moreover, we do not reject the hypotheses of equality in nationality and years of education of the mother and father of the original squatter across the groups, 
suggesting that these groups had been showing similar trends in their socio-economic development before their arrival to this area. ${ }^{11}$ The similarity across pre-treatment characteristics is consistent with the exogeneity in the allocation of property rights described above.

Table 1 - Pre-Treatment Characteristics

\begin{tabular}{|c|c|c|c|}
\hline & $\begin{array}{l}\text { Property Right } \\
\text { Offer }=0\end{array}$ & $\begin{array}{c}\text { Property Right } \\
\text { Offer }=1\end{array}$ & Difference \\
\hline \multicolumn{4}{|c|}{ A. Characteristics of the Parcel } \\
\hline $\begin{array}{l}\text { Distance to Creek } \\
\text { (in blocks) }\end{array}$ & $\begin{array}{c}1.995 \\
(0.061) \\
\end{array}$ & $\begin{array}{c}1.906 \\
(0.034) \\
\end{array}$ & $\begin{array}{c}0.088 \\
(0.070) \\
\end{array}$ \\
\hline $\begin{array}{l}\text { Distance to Non-Squatted } \\
\text { Area (in blocks) }\end{array}$ & $\begin{array}{c}1.731 \\
(0.058)\end{array}$ & $\begin{array}{c}1.767 \\
(0.033)\end{array}$ & $\begin{array}{l}-0.036 \\
(0.067)\end{array}$ \\
\hline $\begin{array}{l}\text { Parcel Size } \\
\text { (in squared meters) }\end{array}$ & $\begin{array}{l}287.219 \\
(4.855) \\
\end{array}$ & $\begin{array}{r}277.662 \\
(2.799) \\
\end{array}$ & $\begin{array}{l}9.556^{*} \\
(5.605)\end{array}$ \\
\hline Block Corner=1 & $\begin{array}{l}0.190 \\
(0.019)\end{array}$ & $\begin{array}{c}0.156 \\
(0.014)\end{array}$ & $\begin{array}{c}0.033 \\
(0.023)\end{array}$ \\
\hline \multicolumn{4}{|c|}{ B. Characteristics of the Original Squatter } \\
\hline (r) & $\begin{array}{l}48.875 \\
(0.938) \\
\end{array}$ & $\begin{array}{l}50.406 \\
(0.761)\end{array}$ & $\begin{array}{l}-1.532 \\
(1.208) \\
\end{array}$ \\
\hline Female $=1$ & $\begin{array}{c}0.407 \\
(0.046)\end{array}$ & $\begin{array}{c}0.353 \\
(0.035)\end{array}$ & $\begin{array}{c}0.054 \\
(0.058)\end{array}$ \\
\hline Argentine $=1$ & $\begin{array}{c}0.903 \\
(0.028) \\
\end{array}$ & $\begin{array}{c}0.904 \\
(0.022) \\
\end{array}$ & $\begin{array}{l}-0.001 \\
(0.035) \\
\end{array}$ \\
\hline Years of Education & $\begin{array}{c}6.071 \\
(0.188)\end{array}$ & $\begin{array}{c}5.995 \\
(0.141)\end{array}$ & $\begin{array}{c}0.076 \\
(0.235)\end{array}$ \\
\hline Argentine Father $=1$ & $\begin{array}{c}0.795 \\
(0.038)\end{array}$ & $\begin{array}{c}0.866 \\
(0.025) \\
\end{array}$ & $\begin{array}{l}-0.072 \\
(0.046)\end{array}$ \\
\hline $\begin{array}{l}\text { Years of Education of the } \\
\text { Father }\end{array}$ & $\begin{array}{c}4.655 \\
(0.147) \\
\end{array}$ & $\begin{array}{c}4.417 \\
(0.076)\end{array}$ & $\begin{array}{c}0.237 \\
(0.165) \\
\end{array}$ \\
\hline Argentine Mother=1 & $\begin{array}{c}0.804 \\
(0.038)\end{array}$ & $\begin{array}{c}0.856 \\
(0.026)\end{array}$ & $\begin{array}{l}-0.052 \\
(0.046)\end{array}$ \\
\hline $\begin{array}{l}\text { Years of Education of the } \\
\text { Mother }\end{array}$ & $\begin{array}{c}4.509 \\
(0.122) \\
\end{array}$ & $\begin{array}{c}4.548 \\
(0.085)\end{array}$ & $\begin{array}{l}-0.039 \\
(0.149)\end{array}$ \\
\hline
\end{tabular}

Notes: Standard errors are in parentheses. ${ }^{*}$ Significant at $10 \%$.

\footnotetext{
${ }^{11}$ In 23 percent of the cases, the current household head does not coincide with the original squatter, either because she/he arrived later than the first member of the family that occupied the parcel, or because she/he arrived at the same time but was not the household head at the arrival time. This percentage is similar for the treatment and control groups. We obtain similar results when we compare the pre-treatment characteristics of the current household head between the two groups.
} 
Once treatment status has been shown to be exogenous, estimation of average treatment effects is straightforward. Operationally, we analyze the effect of land titling on variable $Y$ by estimating the following regression model:

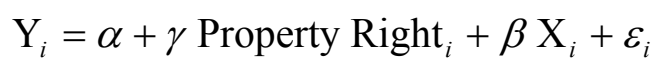

where $Y$ is any of the outcomes under study, and $\gamma$ is the parameter of interest, which captures the causal effect of Property Right (a dummy variable that equals 1 for the squatters that received property titles, and 0 otherwise) on the outcome under consideration. $^{12} \mathrm{X}$ is a vector of pre-treatment parcel and original squatter characteristics, and $\varepsilon$ is the error term. ${ }^{13}$

A typical concern when conducting statistical inference after estimating the parameters of equation (1) is that the errors in that equation might not be independent across households. In order to control for this potential nuisance, we also compute robust standard errors by clustering the parcels located in the same block and the parcels belonging to the same former owner. ${ }^{14}$ These standard errors are also robust to lack of homoskedasticity in the error term. For the education regressions, which comprise more than one child per household, we also cluster the standard errors at the household level. $^{15}$

\footnotetext{
12 Some of the variables under study are Limited Dependent Variables (LDV). The problem of causal inference with LDV is not fundamentally different from the problem of causal inference with continuous outcomes. If there are no covariates or the covariates are sparse and discrete, linear models (and associated estimation techniques like 2SLS) are no less appropriate for LDV than for other types of dependent variables. This is certainly the case in a natural experiment where controls are only included to improve efficiency, but their omission would not bias the estimates of the parameters of interest.

${ }^{13}$ Our estimates show no change if we include as controls the personal characteristics of the current household head instead of those of the original squatter, when they differ.

${ }^{14}$ For the former owner clustering, if a set of parcels overlaps on the borders of the previous tract divisions, occupying a piece of land that belonged to one owner and another piece that corresponded to another owner, the former owner is defined as the combination of the two former owners. For the block clustering, a block is defined as both sides of the segment of a street between two corners. These procedures define 18 former owner clusters and 83 block clusters. Similar results are obtained using other clustering units, such as each sidewalk of a block or the rectangular block delimited by consecutive streets, or by block-bootstrapping the t-test statistic to better approximate the finite sample distribution of our estimators when we allow for the possibility of lack of independence in the error terms within parcels belonging to the same former owner. These other specifications are available from the authors upon request.

${ }^{15}$ We also consider the possibility that the treatment received by one unit could affect the outcomes of other units. In particular, we explore whether titling not only affected the titled parcels
} 
To this point, our model has assumed that all the squatters actually received the treatment to which they were assigned. In many experiments, however, a portion of the participants fail to follow the treatment protocol, a problem termed treatment noncompliance. In our case, this might be of potential concern since a number of families that were offered the possibility of obtaining land titles did not receive them for reasons that may also affect their outcomes. In order to address this problem of non-compliance, we also report the reduced-form estimates from regressing the outcomes of interest on the intention-to-treat Property Right Offer variable, a dummy indicating the availability of land title offers, and also the 2SLS estimates of the treatment effects from instrumenting the Property Right variable with the Property Right Offer variable.

Finally, in any investigation where the impact takes time to materialize (like the investment, household size and long-term education achievement considered in this paper), some participants will inevitably drop out from the analysis. For example, the most widely used longitudinal dataset in economics, the Michigan Panel Study on Income Dynamics, has experienced a 50 percent sample loss from cumulative attrition after 30 years from its initial sample (see Fitzgerald et al., 1998). ${ }^{16}$ Participation attrition, hence, is another potential problem that might bias the estimates of causal effects in long-term studies.

In our 2003 survey, we asked each family the time of arrival to the parcel they are currently occupying, and found that some families arrived after the (early) treatment was assigned, i.e. after the former owners made, during 1986, the decision of surrender the land or sue. From the sample of 467 interviewed households, we found that 313 families

but also the nearest untitled parcels through spillover effects. This possibility is analyzed by splitting the control group into parcels up to or more than two blocks away from the nearest titled parcel. Not only our results remain unchanged but also we do not find significant differences between the two groups of control parcels considered. Moreover, for the education outcomes, which are estimated at the child level and for which we have each child's family name, we follow Angelucci et al (2010) and aim to model intra-family spillovers splitting the control group between those children who share their family name with a child in the treatment group and those that do not. This exercise is done, however, under the limitation that in Argentina individuals do not carry both paternal and maternal family names, but almost exclusively the paternal family name (in our sample, only $1.75 \%$ of the children carry two family names, but even in those cases both names could correspond to the father). Again, our results do not change and there are no significant differences between the two types of control units considered in these econometric exercises. All these results are also available from the authors upon request.

${ }^{16}$ See also, for example, Alderman et al. (2003) and Behrman et al. (2003). 
had arrived to the parcel before the end of 1985, while 154 families arrived after $1985 .^{17}$ As it is plausible to argue that the families that arrived after the former owners' decisions could have known the different expropriation status (i.e., the different probabilities of receiving the land) associated to each parcel, in order to guarantee exogeneity we need to exclude from the analysis the families that arrived to the parcel they are currently occupying after 1985. Once this exclusion is made, there is basically no variability (nor differences between treatment and control groups) in our sample in the year of arrival of the households to the parcels they are currently occupying.

This raises, however, a problem of attrition. If some families arrived after 1985, they could have replaced some original squatters in our treatment and control parcels that had left before we ran our survey in $2003 .{ }^{18}$ Moreover, the availability of titles (combined with the ten-year limitation to legally transfer titled parcels) could have affected household migration decisions. Indeed, column (1) of Table 2 shows that 62.4 percent of the parcels in the non-intention-to-treat group are inhabited by families that arrived before 1986 , while the proportion is 70.0 percent for the intention-to-treat group in the second column. ${ }^{19}$

Table 2 - Household Attrition

\begin{tabular}{|l|c|c|c|c|}
\hline \multicolumn{1}{|c|}{ Variables } & $\begin{array}{c}\text { Property } \\
\text { Right } \\
\text { Offer=0 } \\
(1)\end{array}$ & $\begin{array}{c}\text { Property } \\
\text { Right } \\
\text { Offer=1 } \\
(2)\end{array}$ & $\begin{array}{c}\text { Property } \\
\text { Right Offer } \\
1989=1 \\
(3)\end{array}$ & $\begin{array}{c}\text { Property } \\
\text { Right Offer } \\
1998=1 \\
(4)\end{array}$ \\
\hline Household arrived before & 0.624 & 0.700 & 0.729 & 0.689 \\
$1986=1$ & $(0.036)$ & $(0.028)$ & $(0.051)$ & $(0.033)$ \\
\hline Difference relative to & & $-0.076^{*}$ & $-0.105^{*}$ & -0.064 \\
column (1) & & $(0.045)$ & $(0.063)$ & $(0.049)$ \\
\hline
\end{tabular}

Notes: Standard errors are in parentheses. ${ }^{*}$ Significant at $10 \%$.

17 To identify with accuracy the time of arrival of each family to the parcel they are currently occupying, our survey asked where the original squatter was living when Diego Maradona scored the 'Hand of God' goal in the 1986 World Cup game against England. It is impossible for an Argentine not to remember where she/he was on that day (Amis, 2004).

18 For the families that arrived after 1985, our questionnaire attempted to collect information on the names and destination of the previous occupants of the parcels. In both treatment and control parcels, the current occupants could provide a name and/or destination of the previous occupant only for less than 20 percent of the cases. Although the information obtained is not sufficient to allow us to analyze migration decisions as an outcome of independent interest, it does not suggest that the households that left the untitled parcels moved to richer areas than the families that left the titled parcels. Interestingly, when we asked in these cases whether the current inhabitants rent the house from a previous occupant, we found -although the number of cases is very small- that renting is significantly more frequent in titled parcels.

${ }^{19}$ These survival rates could be overestimating attrition by assuming that there were no vacated parcels left after the occupation. 
Of course, the migration decision could be potentially correlated with the outcomes under study. We exploit two alternative strategies to address this potential nuisance. Our first strategy takes advantage of the asynchronous timing in the titling process to consider, separately, the early and late treatment groups. Although, relative to the control group, the third column of Table 2 shows a significant difference in attrition for the parcels titled in 1989 (early treatment), the last column shows no statistically significant difference for the parcels titled in 1998 (late treatment). Moreover, the unobservable variables that might have affected migration decisions are, a priori, more likely to be ignorable when comparing the control and late treatment groups than when comparing the control and early treatment groups. This is so because the squatters titled in 1998 were under the same conditions as those in the control group for 17 out of the 22 years elapsed from the land invasion to the time of our 2003 survey, so we should expect them to have broadly similar experiences. Indeed, most of the out-migration for these two groups occurred during the interim period they were both untitled. The survival rates for the late titled and control groups since 1997 (i.e., just before the late treated received titles) are 0.958 (s.e. 0.014) and 0.939 (s.e. 0.017), respectively. Thus, the estimated effects of land titling for the late titled group are unlikely to be biased by attrition. Additionally, the comparison of these coefficients with those corresponding to the estimated effects of land titling for the early treated group leads to an indirect test of whether attrition in the latter group is also ignorable.

A more standard strategy assumes the data are missing at random conditional on observable characteristics. The idea is then to compare the outcomes for treated and control survivors with similar pre-treatment characteristics. This approach leads to matching methods based on the propensity score of sample selection. The validity of this strategy requires that at least one of the pre-treatment characteristics predicts attrition. The only pre-treatment characteristics available for the whole set of squatters (attrited and non-attrited) are the parcel characteristics reported in Panel A of Table 1. We estimate a Logit model of the likelihood of survival since 1985 on these parcel characteristics, and find that the distance to the nearby polluted and floodable creek has a positive and statistically significant effect on this likelihood. We exploit the variability in attrition induced by this pre-treatment characteristic to correct for sample selection. 
We implement the matching selection correction by means of the method of stratification matching. We estimate the propensity scores and then, keeping fixed the estimated scores across variables and specifications, we eliminate observations outside the common support of the estimated propensity score for the distributions of titled and untitled groups. Next, we divide the range of variation of the propensity score in intervals such that within each interval, treated and control units tend to have on average the same propensity score. Then, the difference between the average outcomes of the treated and the controls is computed within each interval. The parameter of interest is finally obtained as an average of the estimates of each interval weighted by the share of treated units in each interval on all treated units.

\section{Results}

In this section we investigate the causal effect on housing investment, household structure, human capital accumulation, access to credit, and labor earnings, of providing squatters with formal titles of the parcels of land they occupy. This is the treatment of interest in policy analysis in the developing world, where most interventions consist of titling occupied tracts of land to the current inhabitants. ${ }^{20}$

Ownership of property gives its owner multiple rights. In its most complete form, they include the rights to use the asset, to exclude others from using it, to transfer the assets to others, and to persist in these rights (Barzel, 1997). In our natural experiment, the entitled households acquired full property rights (with the only restriction that the parcels cannot be legally transferred for the first ten years after titling). The untitled households, instead, are still living in the occupied parcels without paying rent and property taxes, but they are uncertain about when and if the parcels will be titled. Moreover, the untitled may feel uncertain about which member of the household would receive the title, and they may fear the occupation of their parcels by new squatters before titling. In the meantime, the untitled cannot legally transfer their usufructuary rights.

\footnotetext{
${ }^{20}$ Whether the provision of land titles to squatters in this area could have encouraged new squatting (and therefore, violation of landowners' property rights) in other zones is beyond the scope of our study, but should not be ignored in the evaluation of the overall impact of this type of interventions.
} 


\section{V.1. Effects on Housing Investment}

The possession of land titles may affect the incentives to invest in housing construction through several concurrent mechanisms. The traditional view emphasizes security from seizure. Individuals underinvest if others may seize the fruits of their investments. Land titles can also encourage investment by improving the transferability of the parcels. Even if there were no risk of expropriation, investments in untitled parcels would be highly illiquid, whereas titling reduces the cost of alienation of the assets. A third mechanism is through the credit market. Transferability might allow the use of the land as collateral, diminishing the funding constraints on investment. Finally, a fourth link is that land titles provide poor households with a valuable savings tool. Poor households, especially in unstable macroeconomic environments, lack appropriate savings instruments. Land titles allow households to substitute present consumption and leisure into long-term savings in real property. We now investigate empirically the impact of legal land titles on housing investment.

In Table 3 we summarize the analysis of the effect of property rights on housing investments. An important clarification is that before the occupation this was a wasteland area without any construction. Thus, the treatment and control areas had a similar (i.e., zero) baseline investment level before the occupation. ${ }^{21}$ In each column, we present the coefficient of the treatment dummy Property Right on a different housing characteristic. All the estimates reported in Table 3 are from regressions including controls for pretreatment characteristics of the parcel and the original squatter.

The first two columns present large effects of land titling on the probability of having walls (first column) and roof (second column) of good quality. The proportion of houses with good quality walls rises by 40 percent under land titling, while the increase reaches 47 percent for good quality roof. The third column presents the effect of land titling on the total surface constructed in the parcel. Our results suggest a statistically significant increase of about 12 percent in constructed surface under the presence of land titles. The fourth column shows a statistically significant increase of 16 percent in the proportion of houses with sidewalks made of concrete. In the last column, the variable

${ }^{21}$ In practice, it is not possible to identify one date of construction for these houses. Houses in this neighborhood are typically self-constructed through gradual incorporations (CEUR, 1984; Cespedes, 1984; Izaguirre and Aristizabal, 1988). 
Overall Housing Appearance summarizes the overall aspect of each house using an index from 0 to 100 points assigned by the team of architects. The coefficient shows a large and significant effect of land titling on housing quality. Relative to the baseline average sample value, the estimated effect represents an overall housing improvement of 37 percent associated to titling.

Table 3 - Housing Investment

\begin{tabular}{|c|c|c|c|c|c|}
\hline & $\begin{array}{l}\text { Good } \\
\text { Walls } \\
\text { (1) }\end{array}$ & $\begin{array}{c}\text { Good Roof } \\
\text { (2) }\end{array}$ & $\begin{array}{c}\text { Constructed } \\
\text { Surface } \\
\text { (3) }\end{array}$ & $\begin{array}{c}\text { Concrete } \\
\text { Sidewalk } \\
\text { (4) }\end{array}$ & $\begin{array}{c}\text { Overall } \\
\text { Housing } \\
\text { Appearance } \\
\text { (5) }\end{array}$ \\
\hline Property Right & $\begin{array}{c}0.20^{* * *} \\
(3.47)\end{array}$ & $\begin{array}{l}0.15^{* *} \\
(2.49)\end{array}$ & $\begin{array}{l}8.27^{\star *} \\
(2.34)\end{array}$ & $\begin{array}{l}0.11^{* *} \\
(2.18)\end{array}$ & $\begin{array}{c}8.42^{* * *} \\
(3.65)\end{array}$ \\
\hline $\begin{array}{l}\text { Control Group Mean } \\
\% \Delta\end{array}$ & $\begin{array}{c}0.50 \\
40.00 \%\end{array}$ & $\begin{array}{c}0.32 \\
46.87 \%\end{array}$ & $\begin{array}{c}67.63 \\
12.23 \%\end{array}$ & $\begin{array}{c}0.67 \\
16.42 \%\end{array}$ & $\begin{array}{c}22.71 \\
37.08 \%\end{array}$ \\
\hline \multicolumn{6}{|c|}{$\begin{array}{l}\text { Notes: Good Walls, Good Roof, and Concrete Sidewalk are dummy variables that equal } 1 \text { if the house has } \\
\text { walls of good quality, a roof of good quality, and a sidewalk made of concrete, respectively, and } 0 \\
\text { otherwise. Constructed surface is measured in squared meters. Overall Housing Appearance measures } \\
\text { the overall aspect of each house from } 0 \text { to } 100 \text { points. The parcel is the unit of observation. All the } \\
\text { regressions control for parcel and original squatter pre-treatment characteristics: parcel size; distance to } \\
\text { creek; distance to nearest non-squatted area; block corner; age, gender, nationality, and years of } \\
\text { education of the original squatter; and nationality and years of education of father and mother of the } \\
\text { original squatter. Variables measured in } 2003 \text {. The robustness of the results and detailed variable } \\
\text { definitions are presented in Table } 4 \text { and Appendix Tables A. } 1 \text { through A.4. Absolute values of t statistics } \\
\text { are in parentheses. }{ }^{* *} \text { Significant at } 5 \% \text {; }{ }^{* * *} \text { significant at } 1 \% \text {. }\end{array}$} \\
\hline
\end{tabular}

In Table 4, we show for the first investment variable (Good Walls) the robustness of the results regarding all the methodological concerns discussed in section IV. For the sake of space, the same analysis is relegated for the other investment variables to Appendix Tables A.1 to A.4, but the five tables should be taken into account for this robustness evaluation. In Table 4, column (1) repeats the model in the first column of Table 3, but displaying all the coefficients (and t-statistics) for the control variables. In column (2), we start with a simple model without including any control variables, while in column (3) we add back the control variables for the parcel characteristics. In these two alternative specifications, the point estimates on the variable of interest are very similar to those in column (1). In column (4) we add the observations for the San Martin neighborhood that were excluded from the baseline analysis in order to enhance geographical comparability between treatment and control groups (see Section III). The point estimate is smaller to that in the baseline model in column (1), but the difference is not statistically significant. 
Table 4 - Robustness of Housing Investment Results: Good Walls

\begin{tabular}{|c|c|c|c|c|c|c|c|c|c|c|c|}
\hline \multirow[b]{2}{*}{ Property Right } & (1) & (2) & (3) & (4) & (5) & (6) & (7) & (8) & (9) & $(10)$ & (11) \\
\hline & $\begin{array}{c}0.20^{\star \star *} \\
(3.47)\end{array}$ & $\begin{array}{c}0.19^{\star * *} \\
(3.32)\end{array}$ & $\begin{array}{c}0.19^{\star \star *} \\
(3.37)\end{array}$ & $\begin{array}{c}0.14^{\star \star \star} \\
(2.65)\end{array}$ & $\begin{array}{c}0.20^{* \star *} \\
(3.18)\end{array}$ & $\begin{array}{c}0.20^{* * *} \\
(4.20)\end{array}$ & & $\begin{array}{c}0.18^{* \star *} \\
(2.62)\end{array}$ & & $\begin{array}{c}0.21^{* * *} \\
(3.34)\end{array}$ & $\begin{array}{l}0.11^{* *} \\
(2.35)\end{array}$ \\
\hline Property Right Offer & & & & & & & $\begin{array}{c}0.16^{* * *} \\
(2.59)\end{array}$ & & & & \\
\hline Property Right 1989 & & & & & & & & & $\begin{array}{c}0.23^{* * *} \\
(2.77)\end{array}$ & & \\
\hline Property Right 1998 & & & & & & & & & $\begin{array}{c}0.19^{* * *} \\
(2.90)\end{array}$ & & \\
\hline Parcel Surface & $\begin{array}{c}-0.00^{\star * *} \\
(2.69)\end{array}$ & & $\begin{array}{c}-0.00^{* * *} \\
(2.65)\end{array}$ & $\begin{array}{c}-0.00^{* *} \\
(2.19)\end{array}$ & $\begin{array}{c}-0.00^{* *} \\
(2.23)\end{array}$ & $\begin{array}{c}-0.00^{* * *} \\
(4.15)\end{array}$ & $\begin{array}{c}-0.00^{* *} \\
(2.47)\end{array}$ & $\begin{array}{c}-0.00^{* * *} \\
(2.74)\end{array}$ & $\begin{array}{c}-0.00^{* * *} \\
(2.70)\end{array}$ & & $\begin{array}{c}-0.00^{* *} \\
(2.44)\end{array}$ \\
\hline Distance to Creek & $\begin{array}{l}0.07^{\star \star} \\
(2.31)\end{array}$ & & $\begin{array}{l}0.07^{\star *} \\
(2.29)\end{array}$ & $\begin{array}{c}0.02 \\
(0.88)\end{array}$ & $\begin{array}{l}0.07^{\star *} \\
(2.47)\end{array}$ & $\begin{array}{c}0.07^{* * *} \\
(2.99)\end{array}$ & $\begin{array}{l}0.07^{* *} \\
(2.26)\end{array}$ & $\begin{array}{l}0.07^{* *} \\
(2.21)\end{array}$ & $\begin{array}{l}0.07^{\star *} \\
(2.11)\end{array}$ & & $\begin{array}{c}0.08^{* * *} \\
(3.27)\end{array}$ \\
\hline Block Corner & $\begin{array}{l}-0.06 \\
(0.66)\end{array}$ & & $\begin{array}{l}-0.09 \\
(1.15)\end{array}$ & $\begin{array}{l}-0.01 \\
(0.17)\end{array}$ & $\begin{array}{l}-0.06 \\
(0.68)\end{array}$ & $\begin{array}{l}-0.06 \\
(0.83)\end{array}$ & $\begin{array}{l}-0.04 \\
(0.45)\end{array}$ & $\begin{array}{l}-0.06 \\
(0.71)\end{array}$ & $\begin{array}{l}-0.06 \\
(0.67)\end{array}$ & & $\begin{array}{l}-0.09 \\
(1.28)\end{array}$ \\
\hline Distance to Non-Squatted & 0.03 & & 0.04 & $0.05^{*}$ & 0.03 & 0.03 & 0.03 & 0.03 & 0.03 & & 0.02 \\
\hline Area & $(0.97)$ & & $(1.49)$ & $(1.80)$ & $(0.84)$ & $(1.65)$ & $(0.91)$ & $(0.96)$ & $(0.97)$ & & $(0.89)$ \\
\hline Age of Original Squatter $<50$ & $\begin{array}{c}0.01 \\
(0.18)\end{array}$ & & & $\begin{array}{l}-0.02 \\
(0.47)\end{array}$ & $\begin{array}{c}0.01 \\
(0.18)\end{array}$ & $\begin{array}{c}0.01 \\
(0.32)\end{array}$ & $\begin{array}{c}0.00 \\
(0.03)\end{array}$ & $\begin{array}{c}0.01 \\
(0.16)\end{array}$ & $\begin{array}{c}0.01 \\
(0.16)\end{array}$ & & \\
\hline Female Original Squatter & $\begin{array}{c}0.05 \\
(0.81)\end{array}$ & & & $\begin{array}{l}-0.05 \\
(0.99)\end{array}$ & $\begin{array}{c}0.05 \\
(0.82)\end{array}$ & $\begin{array}{c}0.05 \\
(0.80)\end{array}$ & $\begin{array}{c}0.05 \\
(0.83)\end{array}$ & $\begin{array}{c}0.05 \\
(0.81)\end{array}$ & $\begin{array}{c}0.05 \\
(0.81)\end{array}$ & & \\
\hline Argentine Original Squatter & $\begin{array}{l}-0.16 \\
(1.12)\end{array}$ & & & $\begin{array}{l}-0.12 \\
(0.95)\end{array}$ & $\begin{array}{l}-0.16 \\
(1.23)\end{array}$ & $\begin{array}{l}-0.16 \\
(1.24)\end{array}$ & $\begin{array}{l}-0.17 \\
(1.21)\end{array}$ & $\begin{array}{l}-0.17 \\
(1.16)\end{array}$ & $\begin{array}{l}-0.16 \\
(1.13)\end{array}$ & & \\
\hline Years of Education of the & -0.02 & & & -0.01 & -0.02 & -0.02 & -0.02 & -0.02 & -0.02 & & \\
\hline Original Squatter & $(1.03)$ & & & $(0.60)$ & $(0.98)$ & $(1.37)$ & $(1.05)$ & $(1.02)$ & $(1.04)$ & & \\
\hline Argentine Father of the & $-0.23^{* *}$ & & & -0.16 & $-0.23^{* *}$ & $-0.23^{* \star *}$ & $-0.23^{* *}$ & $-0.23^{* *}$ & $-0.23^{* *}$ & & \\
\hline Original Squatter & $(2.03)$ & & & $(1.52)$ & $(2.59)$ & (3.53) & $(2.02)$ & $(1.99)$ & $(2.01)$ & & \\
\hline Years of Education of & 0.02 & & & -0.01 & 0.02 & 0.02 & 0.01 & 0.01 & 0.02 & & \\
\hline Original Squatter's Father & $(0.60)$ & & & $(0.35)$ & $(0.66)$ & $(0.78)$ & $(0.54)$ & $(0.55)$ & $(0.61)$ & & \\
\hline Argentine Mother of the & $0.27^{* *}$ & & & 0.15 & $0.27^{\star \star}$ & 0.27 & $0.28^{* *}$ & $0.27^{* *}$ & $0.27^{* *}$ & & \\
\hline Original Squatter & $(2.38)$ & & & $(1.42)$ & $(2.18)$ & $(1.49)$ & $(2.45)$ & $(2.41)$ & $(2.36)$ & & \\
\hline $\begin{array}{l}\text { Years of Education of } \\
\text { Oriqinal Squatter's Mother }\end{array}$ & $\begin{array}{c}0.00 \\
(0.08)\end{array}$ & & & $\begin{array}{c}0.03 \\
(0.96)\end{array}$ & $\begin{array}{c}0.00 \\
(0.08)\end{array}$ & $\begin{array}{c}0.00 \\
(0.12)\end{array}$ & $\begin{array}{c}0.00 \\
(0.11)\end{array}$ & $\begin{array}{c}0.00 \\
(0.11)\end{array}$ & $\begin{array}{c}0.00 \\
(0.07)\end{array}$ & & \\
\hline Constant & $\begin{array}{l}0.71^{* * *} \\
(3.09)\end{array}$ & $\begin{array}{l}0.50^{\star * *} \\
(11.92)\end{array}$ & $\begin{array}{c}0.58^{\star * *} \\
(3.81)\end{array}$ & $\begin{array}{l}0.66^{* * *} \\
(3.54)\end{array}$ & $\begin{array}{l}0.71^{* *} \\
(2.49)\end{array}$ & $\begin{array}{l}0.71^{* * *} \\
(4.54)\end{array}$ & $\begin{array}{l}0.72^{* * *} \\
(3.05)\end{array}$ & $\begin{array}{l}0.73^{* * *} \\
(3.18)\end{array}$ & $\begin{array}{c}0.72^{* * *} \\
(3.11) \\
0.16\end{array}$ & & $\begin{array}{c}0.57^{* * *} \\
(4.78)\end{array}$ \\
\hline Observations & 295 & 295 & 295 & 403 & 295 & 295 & 295 & 295 & 295 & 273 & 441 \\
\hline $\begin{array}{l}\text { Notes: The dependent varial } \\
\text { and } 0 \text { otherwise. The parcel } \\
\text { and Column (3) only controls } \\
\text { at the block level are used in } \\
\text { Property Right Offer is displa } \\
\text { variable Property Right Offer } \\
\text { hypothesis: Property Right } 1 \\
\text { attrition (with bootstrapped s } \\
\text { arrival). The control variables } \\
5 \% ;{ }^{* \star \star} \text { significant at } 1 \% \text {. }\end{array}$ & $\begin{array}{l}\text { Column } \\
\text { yed in Co } \\
\text { is presen } \\
89=\text { Pror } \\
\text { andard err } \\
\text { are descr }\end{array}$ & $\begin{array}{l}\text { ny that e } \\
\text { f observa } \\
\text { naracteris } \\
\text { and at } \mathrm{t} \\
\mathrm{nn}(7) . \mathrm{T} \\
\mathrm{d} \text { in Colur } \\
\text { rty Right } \\
\text { s). The } \mathrm{r} \\
\text { ed in Apr }\end{array}$ & $\begin{array}{l}\text { 2SLS r } \\
\text { (8). Col } \\
\text { res. Colu } \\
\text { ndix Tab }\end{array}$ & $\begin{array}{l}\text { ression ( } \\
\text { n (9) sh } \\
\text { n (10) pr } \\
\text { Column ( } \\
\text { A.1. Abs }\end{array}$ & $\begin{array}{l}\text { strument } \\
\text { s separo } \\
\text { ents the } \\
\text { ) is estir } \\
\text { te value }\end{array}$ & $\begin{array}{l}\text { ions for } t \\
\text { ). The re } \\
\text { the treat } \\
\text { ly the effe } \\
\text { atching e } \\
\text { ted on all } \\
t \text { statisti }\end{array}$ & $\begin{array}{l}\text { ent varia } \\
\text { of early } \\
\text { mate us } \\
\text { in intervi } \\
\text { in paren }\end{array}$ & $\begin{array}{l}\text { Proper } \\
\text { d late tre } \\
\text { the pro }\end{array}$ & $\begin{array}{l}\text { lood. Sta } \\
\text { n the int } \\
\text { Right wit } \\
\text { ments. T } \\
\text { nsity sco } \\
\text { olds (for } \\
\text { nificant a }\end{array}$ & $\begin{array}{l}\text { he inten } \\
\text { F-stat te } \\
\text { of the p } \\
y \text { time of } \\
0 \% ;{ }^{* *} \mathrm{~s}\end{array}$ & $\begin{array}{l}\text { siding), } \\
\text { controls, } \\
\text { lustered } \\
\text { variable } \\
\text {-to-treat } \\
\text { the null } \\
\text { ability of } \\
\text { usehold } \\
\text { ificant }\end{array}$ \\
\hline
\end{tabular}


In columns (5) and (6) we address the potential presence of error correlation by computing t-statistics using robust standard errors after clustering the parcels located in the same block and the parcels from the same former owner. The significance level of the variable of interest remains unaltered. For the other four investment variables, we also find that the significance levels of the Property Right variable remain basically unaltered when clustered standard errors are computed.

Columns (7) and (8) deal with the potential problem of non-compliance. In column (7) we estimate the reduced-form parameter on the intention-to-treat Property Right Offer variable, while in column (8) we report the 2SLS estimates of instrumenting the Property Right variable with Property Right Offer. For the five investment variables, both estimates are very similar to those obtained from OLS in the baseline specification and the differences are not statistically significant at conventional levels, suggesting that noncompliance is not an issue of concern in our sample. ${ }^{22}$

In Columns (9) and (10) we address the concern that these results might be generated by attrition in the original squatter population and are not the cause of treatment. In Column (9) we separately report the effects for early and late land titling, exploiting the fact that, as shown in Table 2, the attrition rates of the late-treated and control groups are not significantly different. The results show that both the early and late treatments have positive significant effects on Good Walls and the other investment variables. For all the variables, the point estimates for the late treatment coefficient are very similar to the ones in the baseline specification in column (1). Moreover, the F-statistics show that we cannot reject the null hypotheses that the effects for the early-treated group and latetreated group are similar at conventional levels of significance. ${ }^{23}$ Column (10) reports the matching estimates discussed in the previous section. Again, for Good Walls and the other investment variables, the point estimates are quite similar to those in the baseline

\footnotetext{
${ }^{22}$ The first-stage regression of Property Right on Property Right Offer is very strong. For the households that arrived before 1986 (i.e. the non-attrited group) and live in parcels offered for titling, the non-compliance rate is $11.2 \%$ ( $9.3 \%$ for the early treated, and $12 \%$ for the late treated).

${ }^{23}$ If one was still to worry about the possibility that the former owners' decisions of accepting or disputing the government offer was correlated with land or squatter characteristics, the significance of the late-treatment coefficients and their similarity with the early-treatment ones should be reassuring. In both the late-treated and control areas, the squatters settled on eventually contested tracts of land and are, therefore, homogenous regarding the decisions of their respective original owners (see section II).
} 
specification and the differences are never statistically significant. Thus, the evidence suggests that the estimates in Table 3 identify the causal effect of land titling on investment and not a statistical artifact due to attrition.

Finally, in column (11) we consider the whole sample of 448 parcels where households were interviewed, instead of considering only the parcels occupied by households that arrived before the time the former owners decided to surrender the land or sue. This analysis investigates a different parameter than the one considered so far. The estimated coefficient measures the causal effect of securing property rights on investment in a given parcel regardless of whether the family occupying it could have changed over time. ${ }^{24}$ The estimated coefficients for the different investment variables are sometimes smaller but, overall, of similar magnitude to those in the baseline models.

A final question relates to the interpretation of the identified causal effect of land titling on investment. Is this an incentive effect induced by owning formal property rights, or is it mainly a wealth effect from titled households that became richer, housing being a normal good? The evidence suggests the treatment operates by affecting the incentives to invest. First, the size of the differential wealth transfer was moderate (see footnote 3 ) and seems considerably smaller than the value of the constructed dwellings. ${ }^{25}$ Second, the families could not have financed the investments with the wealth transfer. It would be impossible to sell the land and, at the same time, invest the collected money on it. Moreover, access to credit improved little with titling (see section V.4). Third, Appendix Table 5 shows no differences in the consumption of durable goods (refrigerators, freezers, washing machines, TV sets and cellular phones). This suggests that the large investment effects presented in this section are a result of a change in the relative returns to housing investment induced by the land titles, and not just a response to a wealth effect that should have also affected positively the consumption of these goods. ${ }^{26}$

\footnotetext{
${ }^{24}$ In these regressions that ignore household rotation, the estimated coefficient can be interpreted as "what grows in a parcel when it is entitled" regardless of whether the same family has always been occupying it or has been replaced by another one. Instead, the estimates obtained exclusively on the non-attrited households measure "what a given family builds in a parcel when receives a land title".

${ }^{25}$ For areas of this level of development in the Buenos Aires outskirts, Zavalia Lagos (2005) estimates that the values of the constructed houses exceed the parcel values by five times.

${ }^{26}$ There are no differences in the access to public services. Basically all the households (titled and untitled) have connections to the water and electricity networks, whereas there are no sewage and natural gas networks in the area.
} 
We conclude that moving a poor household from usufructuary rights to full property rights substantially improves housing quality. The estimated effects are large and robust, and seem to be the result of changes in the economic returns to housing investment induced by land titling. Thus, our micro evidence supports the hypothesis that securing property rights significantly increases investment levels. ${ }^{27}$

\section{V.2. Effects on Household Size}

The possession of land titles may also affect the size and structure of households. There are several potential reasons for that to happen. Insurance motives seem to be the most important. The poor lack access to well-functioning insurance markets and pension systems that could protect them during bad times and retirement. With limited access to risk diversification, to savings instruments, and to the social security system, the need for insurance has to be satisfied by other means. A traditional provider of insurance among the poor is the extended family. Another possibility is to use children as future insurance. In particular, old-age security motives can induce higher fertility (see, among others, Cain, 1985, Nugent, 1985, Ray, 1997, and Portner, 2001). ${ }^{28}$ By allowing the use of housing investment as a savings tool, by securing shelter for the old age, and by potentially improving credit access, land titling may provide some of the needed insurance, therefore reducing the demand for household members among the titled group. $^{29}$

\footnotetext{
${ }^{27}$ A rough back-of-the-envelope calculation using our estimates gives that if the $15 \%$ of households in the Province of Buenos Aires who resided in an untitled dwelling (according to the 1991 Census) would be titled, the increase in investment associated to this hypothetical exercise will amount to $1.2 \%$ of provincial GDP.

28 "[An] important question is whether having many children and/or a large extended household is an optimizing strategy allowing households to derive benefits otherwise lost due to poorly functioning markets" (Birdsall 1988, pp. 502).

29 David and Sundstrom (1984) explain the fertility changes in US history using a similar argument. Suppose, they argue, that large families were designed to be old-age insurance for the parents. At the time of independence, the superabundance of arable land meant that the price of land would not rise over time sufficiently to be a nest egg for old age, and children would be needed to care for their aged parents. When, late in the nineteenth century, the best lands were growing scarce, then the rent, and therefore the price, of land already owned and settled would increase becoming a nest egg due to its capital gain. Thus, investment in land operated as a substitute for more children. The scarcer the land, the higher the economic rent and capital gain, and the fewer children needed to provide for the declining years of the parents.
} 
Moreover, the lack of land titles might reduce the ability of household heads to restrict their relatives from residing in their houses. The household heads may feel less powerful to expel or to deny access to members of their extended family when they lack formal titles. The lack of titles may also impede the division of wealth among family members, forcing claimants to live together to enjoy and retain usufructuary rights. For example, siblings (with their spouses and children) may end up having to live together if they cannot divide their inheritance upon the death of their untitled parents. In addition, untitled households may feel in need of increasing the number of family members in order to protect their houses from occupation by other squatters (Lanjouw and Levy, 2002; Field, 2007). Through these concurrent mechanisms, the lack of formal land titles may generate, on average, larger households among the untitled group.

In Table 5, we find large differences in household size between titled and untitled families. Untitled families have an average of 6.06 members, while titled households have 0.95 members less. Table 5 also shows that the difference in household size does not originate in a more frequent presence in the control group of a spouse of the household head (column 2), nor of offspring of the household head older than 13 years old, i.e. born before the first land titles were issued (column 3 ). This last result is important, because it suggests that there were no differences in the number of children of the household head born before treatment. ${ }^{30}$

The difference in household size seems to originate in two factors. First, column (4) of Table 5 shows a higher presence (0.68 members) of non-nuclear relatives in untitled households. Untitled households report a much larger number of further relatives of the household head who are not her/his spouse or offspring (i.e., siblings, parents, in-laws, grandchildren, etc.) than entitled households. ${ }^{31}$

\footnotetext{
${ }^{30}$ The regression in column (3) only considers offspring living in the house. Non-significant differences are also obtained for the total number of household head's offspring older than 13 (i.e., living and not living in the parental home).

31 The hypothesis that extended family members are valuable to protect the house from other squatters would suggest a larger share of males among non-nuclear adult members in the control group than in the treatment group. In our dataset, however, the male proportion of non-nuclear adults is actually smaller in the control group.
} 
Table 5 - Household Size

\begin{tabular}{|l|c|c|c|c|}
\hline & $\begin{array}{c}\text { Number of } \\
\text { Household } \\
\text { Members } \\
(1)\end{array}$ & $\begin{array}{c}\text { Household } \\
\text { Head Spouse }\end{array}$ & $\begin{array}{c}\text { Offspring of } \\
\text { the } \mathrm{HH}(\geq 14 \\
\text { years old) } \\
(3)\end{array}$ & $\begin{array}{c}\text { Other Relatives } \\
\text { (no Spouse or } \\
\text { Offspring of HH) } \\
(4)\end{array}$ \\
\cline { 2 - 5 } Property Right & $\begin{array}{c}-0.95^{* *} \\
(2.81)\end{array}$ & -0.01 & -0.01 & $-0.68^{* * *}$ \\
Control Group Mean & $(0.27)$ & $(0.06)$ & $(3.53)$ \\
$\% \Delta$ Property Right & $-15.68 \%$ & $-1.35 \%$ & $-0.59 \%$ & 1.25 \\
\hline
\end{tabular}

\begin{tabular}{|c|c|c|c|c|}
\hline \multirow[b]{3}{*}{ Property Right } & \multicolumn{2}{|c|}{$\begin{array}{l}\text { Offspring of the } \mathrm{HH} \\
(5-13 \text { years old })\end{array}$} & \multicolumn{2}{|c|}{$\begin{array}{l}\text { Offspring of the } \mathrm{HH} \\
(0-4 \text { years old })\end{array}$} \\
\hline & & (6) & $(7)$ & (8) \\
\hline & $\begin{array}{l}-0.17 \\
(1.18)\end{array}$ & & $\begin{array}{l}-0.07 \\
(1.03)\end{array}$ & \\
\hline Property Right 1989 & & $\begin{array}{l}-0.38^{*} \\
(1.88)\end{array}$ & & $\begin{array}{l}-0.08 \\
(0.81)\end{array}$ \\
\hline Property Right 1998 & & $\begin{array}{l}-0.06 \\
(0.37)\end{array}$ & & $\begin{array}{l}-0.07 \\
(0.86)\end{array}$ \\
\hline $\begin{array}{l}\text { Control Group Mean } \\
\% \Delta \text { Property Right }\end{array}$ & $\begin{array}{c}1.06 \\
-16.04 \%\end{array}$ & 1.06 & $\begin{array}{c}0.33 \\
-21.21 \%\end{array}$ & 0.33 \\
\hline$\% \Delta$ Property Right 1989 & & $-35.85 \%$ & & $-24.24 \%$ \\
\hline \% & & $-5.66 \%$ & & $-21.21 \%$ \\
\hline \multicolumn{5}{|c|}{$\begin{array}{l}\text { Notes: En each column, the dependent variable is the number of household members of each group. The } \\
\text { household is the unit of observation. All the regressions control for parcel and original squatter pre-treatment } \\
\text { characteristics: parcel size; distance to creek; distance to nearest non-squatted area; block corner; age, } \\
\text { gender, nationality, and years of education of the original squatter; and nationality and years of education of } \\
\text { father and mother of the original squatter. Variables measured in } 2003 \text {. The robustness of the results and } \\
\text { detailed variable definitions are presented in Appendix Tables A.6 through A.11. Absolute values of t statistics } \\
\text { are in parentheses. }{ }^{*} \text { Significant at } 10 \% \text {; }{ }^{* * *} \text { significant at } 1 \% \text {. }\end{array}$} \\
\hline
\end{tabular}

Second, the entitled households show a smaller number of offspring of the household head born after the title allocation. To better analyze this result, we split the household heads' offspring into those born between the first and the second title allocation (children between 5 and 13 years old), and those born after the second title allocation (children between 0 and 4 years old). For the 5-13 age group, column (6) of Table 5 shows a significant reduction of $36 \%$ in the number of household heads' children for the earlytreated households. This decrease corresponds to $8.5 \%$ of the sample average of total household heads' offspring. ${ }^{32}$ The effect, instead, is not significant for the late-treated

\footnotetext{
${ }^{32}$ This fertility effect does not depend on whether a woman or a man received the title. According to the expropriation law, the titles were awarded to both the household head and her/his spouse (if married or cohabitating). In our sample, 95.2 percent of the titled parcels include a woman as owner or co-owner.
} 
group. This result is reassuring, since treatment could not have affected fertility for the late-treated group in the 5-13 age bracket as these children were born before titling for this group. For the household heads' children in the $0-4$ age group, column (8) of Table 5 shows that the effect, however, is not significant for both the late and early treated households. A plausible explanation for the lack of significant effects on the number of household heads' offspring of 0-4 years of age is that by 2003 our household heads were fairly old and, therefore, their fertility rate is low. ${ }^{33}$ Still, in both cases the estimated coefficients correspond to a reduction in the number of offspring of more than $20 \%$.

The robustness of these results regarding the methodological concerns discussed in section IV is presented in Appendix Tables A.6 to A.11. ${ }^{34}$ Moreover, the results are robust to controlling for whether the original squatter is the current household head, for the age of the household head, and, in the regressions for the household heads' children of 5-13 and 0-4 years of age, for the number of offspring of the household head previously born. In summary, we find that entitled households are smaller than untitled ones. The larger size of households in the untitled parcels is due to both a larger number of offspring of the household head and a more frequent presence of non-nuclear relatives.

\section{V.3. Effects on Educational Achievement}

The seminal work of Becker and Lewis (1973) advanced the presence of parental tradeoffs between the quantity and the quality of children. This trade-off appears because limited parents' time and resources are spread over more children (see Rosenzweig and Wolpin (1980), Hanushek (1992), and Li et al. (2008) for empirical evidence). If land titling causes a reduction in fertility, it could also induce households to increase educational investments in their children. Moreover, land titling could also have beneficial effects on the education of household heads' offspring through the reduction in

\footnotetext{
${ }^{33}$ Remember that $77 \%$ of them were already the heads of their households at the time of the occupation in 1981 (see footnote 11). In the 2003 survey, the average household head age was 46 years old, and the average age of the female head (the household head if female or the age of his spouse if male) was 43.7 years old.

${ }^{34}$ For those results that should only be present for the early-treated group, we cannot test the robustness of our results by contrasting the effects for the early and late groups. In these cases, we use only the matching estimates as robustness tests to address the attrition concern.
} 
the number of extended family members living in the house and the potential health consequences of improved housing (Goux and Maurin, 2005).

We explore this hypothesis by looking at differences in educational outcomes. In Table 6 we first consider the School Achievement variable, which is the difference between the school grade the child is currently attending or the maximum grade attained (if she/he is not currently attending school) minus the grade corresponding to her/his age. This variable measures the performance of children from primary school on, collapsing differences in school dropout, grade repetition, and age of school initiation. We consider children from 6 years of age (the beginning of primary school) to 20 years of age at the time of the 2007 survey. ${ }^{35}$ For the offspring of the household head in the early-treated households (the households for which in column (6) of Table 5 we found a reduction in the number of members), column (2) of Table 6 shows a large effect on School Achievement. The children in the control group show an average delay of 1.95 years in their school achievement, whereas this delay is 0.69 years shorter for the children in the early-titled parcels. The effect is not significant for the children in the late-treated households, which had not shown a fertility reduction. ${ }^{36}$

How large is this effect of land titling on school achievement? Consider, for example, the successful Mexican anti-poverty program Progresa, which provides monetary transfers to families that are contingent upon their children's regular school attendance. The estimates in Behrman et al. (2005) indicate that if children were to participate in the program between their 6 to 14 years of age, they would experience an increase of 0.6 years in average educational attainment levels, an effect comparable to the one we estimate for land titling in column (2) of Table 6.

In columns (3) and (4), we compare differences in primary school completion. Primary school is mandatory in Argentina and compliance is high, particularly in urban areas. We find no differences in this variable. Children from both titled and untitled households

\footnotetext{
${ }^{35}$ Our approach is similar to the one used in the literature that uses twin births to study the effect of the number of children in the household on children education. The children born before "treatment" (i.e., before the $\mathrm{n}^{\text {th }}$ delivery for which some families in the sample have twins) are also included in the analysis.

${ }^{36}$ The regressions in Table 6 are estimated at the child level and include controls for child age and gender. In addition to clustering the standard errors at the block and former owner levels, Appendix Tables A.12 through A.15 report standard errors clustered at the household level, together with the other robustness checks.
} 
show primary school graduation rates above $80 \%$. Thus, most of the difference in educational performance appears after primary school.

\section{Table 6 - Education}

Offspring of the Household Head

\begin{tabular}{|l|cc|cc|}
\hline & \multicolumn{2}{|c|}{$\begin{array}{c}\text { School Achievement } \\
(6-20 \text { years old })\end{array}$} & \multicolumn{2}{|c|}{$\begin{array}{c}\text { Primary School Completion } \\
(13-20 \text { years old })\end{array}$} \\
\cline { 2 - 4 } Property Right & $(1)$ & $(2)$ & $(3)$ & $(4)$ \\
\cline { 2 - 4 } & 0.22 & & 0.02 & $(0.45)$ \\
Property Right 1989 & $(1.15)$ & $0.69^{* *}$ & & 0.01 \\
Property Right 1998 & & $(2.29)$ & & $0.12)$ \\
& & 0.03 & & $(0.49)$ \\
Control Group Mean & & $(0.13)$ & & 0.82 \\
\hline
\end{tabular}

\begin{tabular}{|c|c|c|c|}
\hline & $\begin{array}{c}\text { Secondary School Completion } \\
(18-20 \text { years old })\end{array}$ & $\begin{array}{r}\text { Post-Sec } \\
\quad(18-\end{array}$ & $\begin{array}{l}\text { Education } \\
\text {; old) }\end{array}$ \\
\hline & $(5)$ & (7) & (8) \\
\hline Property Right & $\begin{array}{c}0.06 \\
(0.72)\end{array}$ & $\begin{array}{l}0.11^{*} \\
(1.91)\end{array}$ & \\
\hline Property Right 1989 & $\begin{array}{l}0.27^{*} \\
(1.93)\end{array}$ & & $\begin{array}{l}0.20^{* *} \\
(2.23)\end{array}$ \\
\hline Property Right 1998 & $\begin{array}{l}-0.01 \\
(0.12)\end{array}$ & & $\begin{array}{c}0.07 \\
(1.18)\end{array}$ \\
\hline Control Group Mean & 0.26 & 0.05 & 0.05 \\
\hline $\begin{array}{l}\text { Notes: In columns (1) anc } \\
\text { is currently attending } \\
\text { corresponding to the chill } \\
\text { the child has finished prir } \\
\text { dummy that equals } 1 \text { if th } \\
\text { dependent variable is a } \\
\text { university), and } 0 \text { otherw } \\
\text { child gender, and parcel } \\
\text { distance to nearest non-s } \\
\text { original squatter; and nat } \\
\text { measured in } 2007 \text {. The rc } \\
\text { Tables A.12 through A. } \\
\text { significant at } 5 \% \text {. }\end{array}$ & $\begin{array}{l}\text { he dependent variable is the difference } \\
\text { maximum grade attained (if not } \\
\text { In columns (3) and (4), the dependen } \\
\text { chool, and } 0 \text { otherwise. In columns ( } 5 \\
\text { I has finished secondary school, and } 0 \\
\text { that equals } 1 \text { if the child has started } \\
\text { he child is the unit of observation. All } \\
\text { riginal squatter pre-treatment characte } \\
d \text { area; block corner; age, gender, nat } \\
\text { y and years of education of original sq } \\
\text { ess of the results and detailed variable } \\
\text { solute values of t statistics are in }\end{array}$ & $\begin{array}{l}\text { etween the } \\
\text { ending sch } \\
\text { ariable is a } \\
\text { nd (6), the } \\
\text { herwise. In } \\
\text { st-seconda } \\
\text { e regressior } \\
\text { tics (parcel } \\
\text { lality, and y } \\
\text { tter's paren } \\
\text { finitions are } \\
\text { entheses. * }\end{array}$ & $\begin{array}{l}\text { de each chil } \\
\text { is the grad } \\
\text { lat equals } 1 \\
\text { t variable is } \\
\text { ) and (8), th } \\
\text { on (tertiary o } \\
\text { for child age } \\
\text { ince to creek } \\
\text { ucation of th } \\
\text { tion variable } \\
\text { d in Appendi } \\
\text { th at } 10 \% \text {; * }\end{array}$ \\
\hline
\end{tabular}

Differences in educational achievement become significant for secondary and postsecondary education. Column (6) of Table 6 shows that secondary school completion is 27 points higher for the offspring of the household head in the early-treated households. Note that for secondary school completion, our regressions consider children between 
18 (the expected age of secondary school graduation) and 20 years of age in 2007 . In the early-titled parcels, these children were born just before treatment. Thus, the effect is only significant for the group of children who were raised in families with a small number of siblings thanks to, according to the estimates in the previous section, the reduction in fertility their parents experienced after titling. Similar results are presented in column (8), which shows that continuation into tertiary or university education is 20 points higher for children in the early-treated households, again the ones that showed the fertility reduction.

Galiani (2010) estimates, using the international poverty line, that $26 \%$ of urban poor complete secondary school in Argentina, which is similar to the achievement of the control group. Among the non-poor, $63 \%$ complete secondary school (59\% is the country urban average). Thus, our results suggest that the early-treated group has significantly reduced the gap between the poor and non-poor groups in the population. According to the 1991 Census, $15 \%$ of households in the Province of Buenos Aires resided in an untitled dwelling, which assuming they all belong to the bottom quintile of the family income per capita distribution, it implies that approximately $25 \%$ of the children currently starting primary school each year in Buenos Aires reside in untitled households. Thus, extrapolation of our results gives that titling the untitled population would imply that approximately $6.75 \%$ more of the population will finish high school $(0.25 \% * 27)$. This would represent an increase of $11.4 \%$ in the total secondary school completion rate.

Finally, it is worth noting that in a standard Mincer earnings equation using wage data from the official Argentine household survey $(\mathrm{EPH}, 2006)$, the returns to secondary school completion and incomplete tertiary education are estimated to be approximately $20 \%$ and $40 \%$, respectively, above those for incomplete secondary school. These large wage differentials augur significant long-term effects on the future labor market returns of the squatters' offspring.

\section{V.4. Effects on Performance in the Credit and Labor Markets}

Financial markets in developing countries are highly imperfect and these imperfections are particularly severe for the poor. The possession of formal property rights could allow the use of land as collateral, improving the access of the poor to the credit markets 
(Feder et al., 1988). In turn, this collateralized credit could be invested as capital, increasing labor productivity and income (De Soto, 2000). Moreover, land titling may have direct labor market effects if it relieves families from the need of leaving adults at home to protect their houses from occupation by other squatters (Field, 2007). We investigate whether land titles improve the performance of households in the credit and labor markets.

Table 7 - Access to Credit

\begin{tabular}{|l|c|c|c|c|}
\hline & $\begin{array}{c}\text { Credit Card } \\
\& \\
\text { Bank Account } \\
(1)\end{array}$ & $\begin{array}{c}\text { Non-Mortgage } \\
\text { Loan } \\
\text { Received } \\
(2)\end{array}$ & $\begin{array}{c}\text { Informal } \\
\text { Credit }\end{array}$ & $\begin{array}{c}\text { Grocery Store } \\
\text { Credit }\end{array}$ \\
\hline Property Right & $\begin{array}{c}-0.01 \\
(0.71)\end{array}$ & $\begin{array}{c}0.01 \\
(0.19)\end{array}$ & $\begin{array}{c}(3) \\
(1.00)\end{array}$ & $(4)$ \\
\hline Control Group Mean & 0.05 & 0.09 & 0.01 & $0.16)$ \\
& & 0.27 & 0.06 \\
\hline
\end{tabular}

\begin{tabular}{|c|c|c|}
\hline & \multicolumn{2}{|c|}{ Mortgage Loan Received } \\
\hline & (5) & (6) \\
\hline Property Right & $\begin{array}{c}0.02 \\
(1.58)\end{array}$ & \\
\hline Property Right 1989 & & $\begin{array}{c}0.04^{* * *} \\
(3.19)\end{array}$ \\
\hline Property Right 1998 & & $\begin{array}{c}0.00 \\
(0.06)\end{array}$ \\
\hline Control Group Mean & 0.00 & 0.00 \\
\hline $\begin{array}{l}\text { Notes: Credit Card \& Bar } \\
\text { card or bank account, a } \\
\text { Credit, and Mortgage Lo } \\
\text { formal non-mortgage cre } \\
\text { from grocery stores; and } \\
\text { of observation. All the re } \\
\text { parcel size; distance to } \\
\text { nationality, and years of } \\
\text { and mother of the origina } \\
\text { variable definitions are } \\
\text { parentheses. }{ }^{* *} \text { Significa }\end{array}$ & $\begin{array}{l}\text { dummy va } \\
\text { Non-Mort } \\
\text { e dummy } \\
\text { lit from rel } \\
\text { e credit; re } \\
\text { ol for parc } \\
\text { e to nea } \\
\text { original so } \\
\text { ables mea } \\
\text { Appendix }\end{array}$ & $\begin{array}{l}\text { sehold head has a credit } \\
\text { al Credit, Grocery Store } \\
\text { household has received } \\
\text { or friends; on trust credit } \\
\text { he household is the unit } \\
\text { eeatment characteristics: } \\
\text { k corner; age, gender, } \\
\text { ars of education of father } \\
\text { egressions and detailed } \\
s \text { of } t \text { statistics are in }\end{array}$ \\
\hline
\end{tabular}

In Table 7 we find no differences across groups in the access to credit cards and banking accounts; and to non-mortgage formal credit from banks, the government, labor unions or cooperatives. Indeed, these families show very little access to these types of formal credit. The access to credit is higher for informal credit from relatives, colleagues, neighbours, and friends, and for on-trust credit that families receive from the stores in 
which they perform their daily purchases. However, titling status shows no effect on access to these informal sources of credit.

In the second panel of Table 7 we analyze the impact of titling on the access to mortgage loans. For this exercise, we separate the effect for the early and late treatment households. The late treatment group was not yet in a legal situation to mortgage the land at the time of the survey, as the ten years established by the expropriation law before allowing property transfers had not elapsed since the 1998 titling (see section II). For the early titled group, although we find a statistically significant effect of land titling on the access to mortgage markets, the effect is quantitatively modest. Only $4 \%$ of the early-treated households have ever received a mortgage loan.

Finally, we investigate the effect of land titling on labor market outcomes. For this exercise, a further advantage of our experiment is that treated and control households are all in the same labor market. In Table 8, we show no differences between control and treatment households in household head income, total household income, total household income per capita, total household income per adult, and employment status of the household head. There are also no significant differences in the pension status of the household heads, in female employment, and in child labor. ${ }^{37}$ In spite of land titling, these families are still very poor. Relative to the population of the Buenos Aires metropolitan area, the households in our sample show low income levels. Their average household income level is in the $25^{\text {th }}$ centile of the income distribution in the official household survey (EPH, May 2003), while their average per capita income is in the $14^{\text {th }}$ centile of the distribution. Moreover, their average household income amounts to only $38 \%$ of the official poverty line, and $94 \%$ of the households are below this line. ${ }^{38}$

\footnotetext{
${ }^{37}$ In our population, the frequency of child labor (for children $10-14$ years old) is $0 \%$ in the treatment group, and $1.05 \%$ in the control group (the difference is not significant). These figures coincide with the negligible levels of child labor for the Buenos Aires metropolitan area $(0.18 \%$ for the overall and $0.29 \%$ for the first income quintile according to the official household survey of May 2003). They are also consistent with the high levels of primary school completion shown in section V.3.

${ }^{38}$ The results on the effects of land titling on the credit and labor markets remain unaltered when we perform all our robustness checks. For the sake of space, Appendix Tables A.16 and A.17 only include the main specification and the early-late regression. The other specifications are available from the authors upon request.
} 
Table 8 - Labor Market

\begin{tabular}{|c|c|c|c|c|c|}
\hline & $\begin{array}{l}\text { Household } \\
\text { Head } \\
\text { Income } \\
\text { (1) }\end{array}$ & $\begin{array}{l}\text { Total } \\
\text { Household } \\
\text { Income }\end{array}$ & $\begin{array}{l}\text { Total } \\
\text { Household } \\
\text { Income } \\
\text { per Capita } \\
\text { (3) }\end{array}$ & $\begin{array}{l}\text { Total } \\
\text { Household } \\
\text { Income } \\
\text { per Adult } \\
\text { (4) }\end{array}$ & $\begin{array}{c}\text { Employed } \\
\text { Household } \\
\text { Head }\end{array}$ \\
\hline Property Right & $\begin{array}{l}-27.35 \\
(1.10)\end{array}$ & $\begin{array}{c}-43.56 \\
(1.27)\end{array}$ & $\begin{array}{c}1.04 \\
(0.13)\end{array}$ & $\begin{array}{l}-4.45 \\
(0.38)\end{array}$ & $\begin{array}{c}0.03 \\
(0.63)\end{array}$ \\
\hline Control Group Mean & 272.54 & 374.59 & 73.72 & 118.73 & 0.73 \\
\hline \multicolumn{6}{|c|}{$\begin{array}{l}\text { Notes: Household Head Income is the total income earned by the household head in the previous month. } \\
\text { Total Household Income is the total income earned by all the household members in the previous month. } \\
\text { Total Household Income per Capita is Total Household Income divided by the number of household } \\
\text { members. Total Household Income per Adult is Total Household Income divided by the number of } \\
\text { household members older than } 16 \text { years old. All income variables are measured in Argentine pesos. } \\
\text { Employed Household Head is a dummy variable that equals } 1 \text { if the household head was employed the } \\
\text { week before the survey, and } 0 \text { otherwise. The household is the unit of observation. All the regressions } \\
\text { control for parcel and original squatter pre-treatment characteristics: parcel size; distance to creek; } \\
\text { distance to nearest non-squatted area; block corner; age, gender, nationality, and years of education of } \\
\text { the original squatter; and nationality and years of education of father and mother of the original squatter. } \\
\text { Variables measured in } 2003 \text {. The complete regressions are presented in Appendix Table A.17. Absolute } \\
\text { values of t statistics are in parentheses. }\end{array}$} \\
\hline
\end{tabular}

The modest effects of titling on the credit markets should not be too surprising. Previous evidence on the credit effects of land titling is ambiguous (see, among others, Feder et al., 1988; Place and Migot-Adholla, 1998; Carter and Olinto, 2002; Field and Torero, 2003; and Calderon, 2004. Also see Woodruff, 2001, for a critical review of De Soto's book). Real estate possession does not seem to be a sufficient condition to qualify for formal credit, which is largely restricted in Argentina to formal workers with requirements of minimum tenure in the current job and high wages. Moreover, potential lenders probably evaluate that success in the legal eviction of households in these socioeconomic groups in the event of default is unlikely (Arrunada, 2003) and, if feasible, the cost of the legal process may exceed the market value of the parcels. In addition, collateralization might have been further limited in our context by the ten-year transfer limitation. Finally, the few observed mortgage loans are probably not invested in business projects. The poor may consider the land too valuable to be jeopardized in an entrepreneurial activity. Thus, the modest credit effects do not further translate into labor market differences. ${ }^{39}$

39 The coexistence of strong investment effects and weak credit market access in our natural experiment can be interpreted as an illustration of Acemoglu and Johnson (2005)'s distinction between institutions that protect citizens against expropriation and institutions that enable private contracts. 


\section{Conclusions}

Land-titling programs have been recently advocated in policy and business circles as a powerful anti-poverty instrument, and several countries in the developing world adopted or are in the process of adopting interventions to provide squatters with formal titles of the land they occupy. The main premise is that land titling could allow the poor to access the credit markets, transforming their wealth into capital and, hence, increase their labor productivity and income. Rigorous evidence supporting these hypothesized effects is, however, scarce and ambiguous. Are land-titling programs an effective tool to rapidly reduce poverty? What are the effects of land titling?

Identifying the causal effects of land titling is difficult because the allocation of property rights across households is not random, but typically endogenous in equations describing the outcomes under study. Previous work exploited standard exclusion restrictions or variability in the timing of policy interventions to deal with this selection problem. In this paper, instead, we exploit a natural experiment in the allocation of land titles across squatters in a poor suburban area of Buenos Aires, Argentina. We believe that our strategy credibly identifies the effect of land titling: untitled and entitled households were extremely similar before titling, the parcels they inhabit are identical, and the allocation of property rights did not depend on the characteristics of the squatters.

We only find a modest but positive effect of land titling on access to mortgage credit, and no impact on access to other forms of credit. Moreover, we do not find any effect on the labor income of the treated households. Should we therefore conclude that entitling the urban poor renders them little progress? Not necessarily. We showed that moving a poor household from usufructuary land rights to full property rights substantially increased investment in the houses. The constructed surface increases by $12 \%$, while an overall index of housing quality rises by $37 \%$. Moreover, households in the titled parcels have a smaller size (an average of 5.11 members relative to 6.06 in the untitled group), both through a reduced fertility of the household heads (when treated being young) and a diminished presence of extended family members. The families that reduced fertility also invested more in the education of their children allowing them to reach educational levels that can help them achieve significant long-term wage differentials. The children from the 
households that reduced fertility show significantly better educational achievement, with an average of 0.69 more years of schooling and twice the completion rate of secondary education ( $53 \%$ vs. $26 \%)$. In sum, entitling the poor increases their investment both in the house and in the human capital of their children, which should contribute to reduce the poverty of the future generations. 


\section{References}

Acemoglu, Daron, Simon Johnson and James Robinson. (2001) "The Colonial Origins of Comparative Development: An Empirical Investigation", American Economic Review, 91, 1369-1401.

Acemoglu, Daron and Simon Johnson (2005). "Unbundling Institutions." Journal of Political Economy, 113(5), pp. 949-995.

Alchian, Armen and Demsetz, Harold (1973). "The Property Rights Paradigm." Journal of Economic History, 33(1), pp. 16-27.

Alderman, Harold; Behrman, Jere; Kohler, Hans-Peter; Maluccio, John and Watkins, Susan (2003). "Attrition in Longitudinal Household Survey Data: Some Tests for Three DevelopingCountry Samples." World Bank Policy Research Working Paper No. 2447.

Alston, Lee; Libecap, Gary and Schneider, Robert (1996). "The Determinants and Impact of Property Rights: Land Titles on the Brazilian Frontier." Journal of Law, Economics \& Organization, 12, pp. 25-61.

Amis, Martin (2004). "In Search of Dieguito." The Guardian, October 1.

Angelucci M., G. De Giorgi, M. Rangel, and I. Rasul, (2010). "Family Networks and School Enrollment: Evidence from a Randomized Social Experiment." forthcoming, Journal of Public Economics.

Arruñada, Benito (2003). "Property Enforcement as Organized Consent", Journal of Law, Economics and Organization, 19, 401-444.

Banerjee, Abhijit and Esther Duflo (2006). "The Economic Lives of the Poor", Journal of Economic Perspectives, 21(1), pp. 141-167.

Banerjee, Abhijit, Paul Gertler and Maaitresh Ghatak (2002). "Empowerment and Efficiency: Tenancy Reform in West Bengal", Journal of Political Economy, 110(2), pp. 239-80.

Barzel, Yoram (1997). Economic Analysis of Property Rights. New York: Cambridge Univ. Press.

Becker, Gary and Lewis, Gregg (1973). "On the Interaction between the Quantity and Quality of Children." Journal of Political Economy, 81(2), pp. S279-88.

Behrman, Jere; Hoddinott, John; Maluccio, John; Quisumbing, Agnes; Martorell, Reynaldo and Stein, Aryeh (2003). "The Impact of Experimental Nutritional Experiments on Education into Adulthood in Rural Guatemala: Preliminary Longitudinal Analysis", mimeo.

Behrman, Jere; Sengupta, Piyali and Todd, Petra (2005). "Progressing through Progresa: An Impact Assessment of a School Subsidy Experiment in Mexico", Economic Development and Cultural Change, 54(1), pp. 237-275.

Bennedsen, Morten; Nielsen, Kasper; Pérez-González, Francisco and Wolfenzon, Daniel (2007). "Inside the Family Firm: The Role of Families in Succession Decisions and Performance." Quarterly Journal of Economics, Vol. 122 (2), pp. 647-691.

Besley, Timothy (1995). "Property Rights and Investments Incentives: Theory and Evidence from Ghana." Journal of Political Economy, 103, pp. 903-37.

Birdsall, Nancy (1988). "Economic Approaches to Population Growth," in H. Chenery and T.N. Srinivasan, eds., Handbook of Development Economics, Volume 1. North Holland: Elsevier.

Brasselle, Anne-Sophie; Gaspart, Frederic and Platteau, Jean-Philippe (2002). "Land Tenure Security and Investment Incentives: Puzzling Evidence from Burkina Faso." Journal of Development Economics, 67(2), pp. 373-418.

Briante, Miguel (1982). "Las Tierras para el Hombre" in El Porteño, reprinted in Miguel Briante (2004), Desde este mundo, Buenos Aires: Sudamericana.

Burkart, Mike; Fausto Panunzi and Andrei Shleifer (2003). "Family Firms." Journal of Finance, 58 (5), pp. 2167-2202.

Cain, Mead (1985). "On the Relationship between Landholding and Fertility." Population Studies, $39(1)$, pp. 5-15.

Calderon, Julio (2004). "The Formalisation of Property in Peru 2001-2002: the Case of Lima." Habitat International, 28, pp. 289-300.

Carter, Michael and Olinto, Pedro (2003). "Getting Institutions Right for Whom? Credit Constraints and the Impact of Property Rights on the Quantity and Composition of Investment." American Journal of Agricultural Economics, 85, pp. 173-86.

Cespedes, Marcelo (1984). Por una Tierra Nuestra. Documentary Movie. 
CEUR (1984). "Condiciones de Hábitat y Salud de los Sectores Populares. Un Estudio Piloto en el Asentamiento San Martín de Quilmes." Buenos Aires: Centro de Estudios Urbanos y Regionales.

David, Paul and Sundstrom, William (1984). "Bargains, Bequests, and Births: An Essay on Intergenerational Conflict, Reciprocity, and the Demand for Children in Agrarian Societies." Stanford Project on the History of Fertility Control, Stanford University, Working Paper No. 12.

Deininger, Klaus (2003), Land Policies for Growth and Poverty Reduction. Washington: World Bank and Oxford University Press

Demsetz, Harold (1967). "Toward a Theory of Property Rights." American Economic Review, 57(2), pp. 347-59.

De Long, J. Bradford and Shleifer, Andrei (1993). "Princes and Merchants: European City Growth before the Industrial Revolution." Journal of Law and Economics, 36(2), pp. 671-702.

De Soto, Hernando (2000). The Mystery of Capital: Why Capitalism Triumphs in the West and Fails Everywhere Else. New York: Basic Books.

Di Tella, Rafael; Sebastián Galiani and Ernesto Schargrodsky (2007). "The Formation of Beliefs: Evidence from the Allocation of Land Titles to Squatters," Quarterly Journal of Economics, Vol. 122 (1), pp. 209-241.

Do, Quy Toan and lyer, Lakshmi (2008). "Land Titling and Rural Transition in Vietnam." Economic Development and Cultural Change 56 (3), pp. 531-579.

Fara, Luis (1989). "Luchas Reivindicativas Urbanas en un Contexto Autoritario. Los Asentamientos de San Francisco Solano," in Elizabeth Jelin, ed., Los Nuevos Movimientos Sociales. Buenos Aires: Centro Editor de América Latina.

Feder, Gerschon; Onchan, Tongroj; Chalamwong, Yongyuth and Hongladarom, Chira (1988). Land Policies and Farm Productivity in Thailand. Baltimore: Johns Hopkins University Press.

Field, Erica (2005). "Property Rights and Investment in Urban Slums." Journal of the European Economic Association, 3(2-3), pp. 279-290.

Field, Erica (2007). "Entitled to Work: Urban Property Rights and Labor Supply in Peru." Quarterly Journal of Economics, Vol. 122, No. 4: 1561-1602.

Field, Erica and Maximo Torero (2003). "Do Property Titles Increase Credit Access among the Urban Poor? Evidence from a Nationwide Titling Program in Peru." Mimeo, Princeton University.

Fiss, Owen (1984). "Against Settlement." The Yale Law Journal, 93(6), pp.1073-1090.

Fitzgerald, John; Gottschalk, Peter and Moffitt, Robert (1998). "An Analysis of Sample Attrition in Panel Data: The Michigan Panel Study of Income Dynamics." Journal of Human Resources, 33(2), pp. 251-299.

Galiani, Sebastian (2010). "Reducing Poverty in Latin America and the Caribbean", forthcoming in Latin American Development Priorities: Costs and Benefits, B. Lomborg (ed.), Cambridge University Press.

Goux, Dominique and Maurin, Eric (2005). "The Effect of Overcrowded Housing on Children's Performance at School." Journal of Public Economics, 89, pp. 797-819.

Hanushek, Eric (1992). "The Trade-off between Child Quantity and Quality." Journal of Political Economy, 100(1), pp. 84-117.

Izaguirre, Ines and Aristizabal, Zulema (1988). Las Tomas de Tierras en la Zona Sur del Gran Buenos Aires. Un Ejercicio de Formación de Poder en el Campo Popular. Buenos Aires: Centro Editor de América Latina.

Jimenez, Emmanuel (1984). "Tenure Security and Urban Squatting." Review of Economics and Statistics, 66(4), pp. 556-67

Johnson, Simon; McMillan, John and Woodruff, Christopher (2002). "Property Rights and Finance." American Economic Review, 92(5), pp. 1335-1356.

Kaplan, Davis S.; Sadka, Joyce and Jorge Luis Silva-Mendez (2006). "Litigation and Settlement: New Evidence from Labor Courts in Mexico." Centro de Investigacion Economica, ITAM, Working Paper No. 606.

Lanjouw, Jean and Levy, Philip (2002). "Untitled: A Study of Formal and Informal Property Rights in Urban Ecuador." Economic Journal, 112, pp. 986-1019.

$\mathrm{Li}$, Hongbin; Junsen Zhang and Yi Zhu (2008). "The Quantity-Quality Trade-Off of Children in a Developing Country: Identification Using Chinese Twins", Demography, 45(1), pp. 223-243. 
Libecap, Gary and Lueck, D. (2008). "The Demarcation of Land: Patterns and Economic Effects." mimeo, UCSD.

North, Douglass (1981). Structure and Change in Economic History. New York: Norton.

North, Douglass and Thomas, Robert (1973). The Rise of the Western World: A New Economic History. New York: Cambridge University Press.

Nugent, Jeffrey (1985). "The Old-Age Security Motive for Fertility." Population and Development Review, 11, pp. 75-97.

Place, Frank and Migot-Adholla, Shem (1998). "The Economic Effects of Land Registration for Smallholder Farms in Kenya: Evidence from Nyeri and Kakamega Districts." Land Economics, 74(3), pp. 360-73.

Portner, Claus (2001). “Children as Insurance." Journal of Population Economics, 14, pp. 119-36.

Ray, Debraj (1997). Development Economics, New Jersey: Princeton University Press.

Rosenzweig, Mark and Wolpin, Kenneth (1980). "Testing the Quantity-Quality Fertility Model: the Use of Twins as a Natural Experiment." Econometrica, 48, pp. 227-40.

Woodruff, Christopher (2001). "Review of De Soto's The Mystery of Capital." Journal of Economic Literature, 39(4), pp.1215-23.

Zavalia Lagos, Raul (2005). "La Confianza como Agente Superador de los Problemas de Vivienda", presentation of Fundacion Pro-Vivienda Social at "Seminario sobre Políticas de Vivienda en Argentina", CEF-World Bank, Buenos Aires, June 30. 


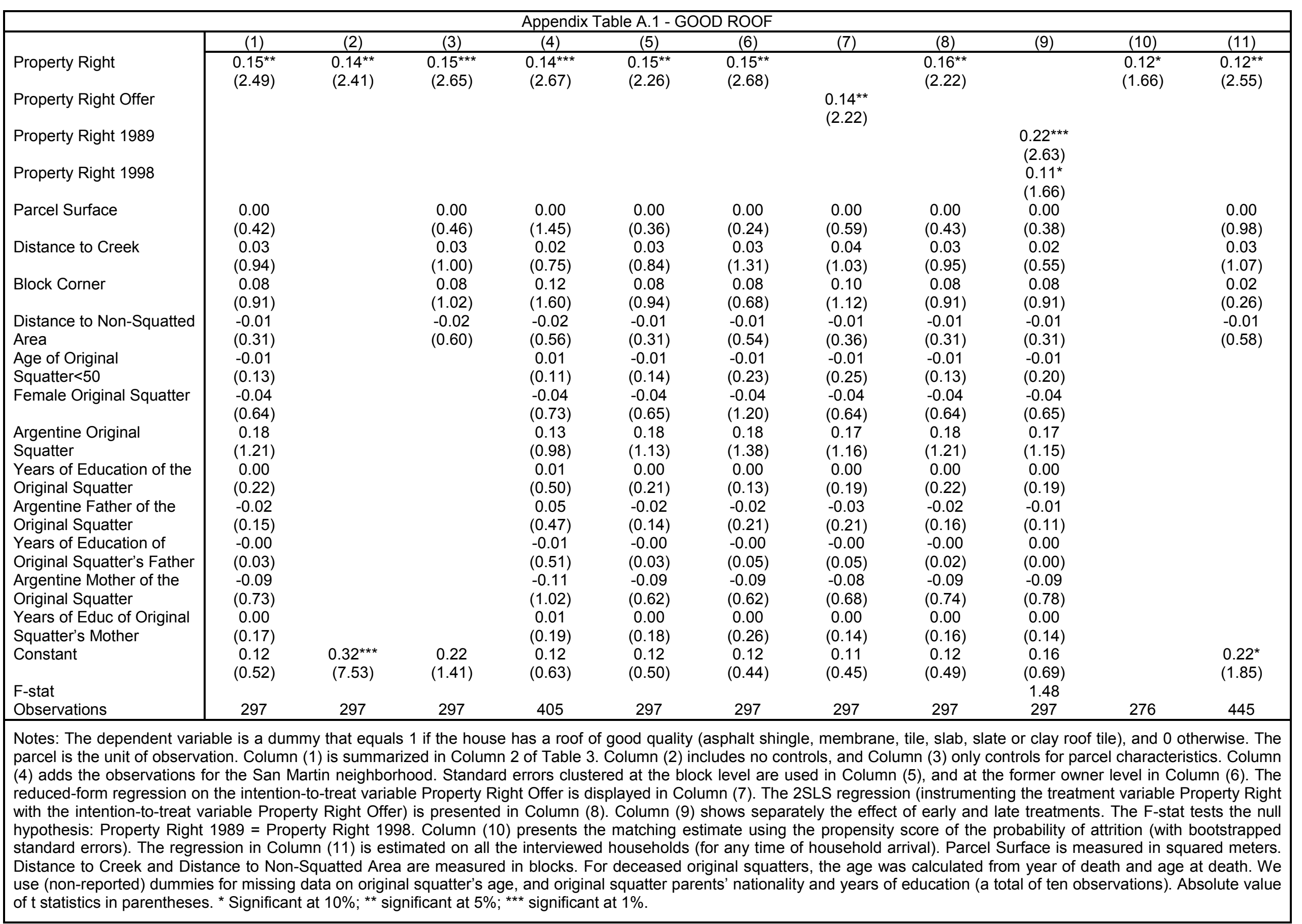




\begin{tabular}{|c|c|c|c|c|c|c|c|c|c|c|c|}
\hline \multicolumn{12}{|c|}{ Appendix Table A.2 - CONSTRUCTED SURFACE } \\
\hline \multirow[b]{2}{*}{ Property Right } & (1) & (2) & (3) & $(4)$ & (5) & $(6)$ & $(7)$ & (8) & (9) & $(10)$ & $(11)$ \\
\hline & $\begin{array}{l}8.27^{\star *} \\
(2.34)\end{array}$ & $\begin{array}{l}7.99^{\star *} \\
(2.33)\end{array}$ & $\begin{array}{c}9.89^{\star * *} \\
(2.87)\end{array}$ & $\begin{array}{l}5.30^{*} \\
(1.68)\end{array}$ & $\begin{array}{l}8.27^{\star \star} \\
(2.15)\end{array}$ & $\begin{array}{c}8.27 \\
(1.44)\end{array}$ & & $\begin{array}{l}9.87^{\star *} \\
(2.41)\end{array}$ & & $\begin{array}{l}8.55^{\star \star} \\
(2.18)\end{array}$ & $\begin{array}{l}8.61^{* * *} \\
(3.02)\end{array}$ \\
\hline Property Right Offer & & & & & & & $\begin{array}{l}9.06^{* *} \\
(2.41)\end{array}$ & & & & \\
\hline Property Right 1989 & & & & & & & & & $\begin{array}{c}10.34^{* *} \\
(2.09)\end{array}$ & & \\
\hline Property Right 1998 & & & & & & & & & $\begin{array}{l}7.18^{*} \\
(1.80)\end{array}$ & & \\
\hline Parcel Surface & $\begin{array}{l}-0.01 \\
(0.36)\end{array}$ & & $\begin{array}{l}-0.00 \\
(0.02)\end{array}$ & $\begin{array}{c}0.01 \\
(0.63)\end{array}$ & $\begin{array}{l}-0.01 \\
(0.37)\end{array}$ & $\begin{array}{l}-0.01 \\
(0.35)\end{array}$ & $\begin{array}{l}-0.00 \\
(0.12)\end{array}$ & $\begin{array}{l}-0.01 \\
(0.31)\end{array}$ & $\begin{array}{l}-0.01 \\
(0.37)\end{array}$ & & $\begin{array}{c}0.01 \\
(0.68)\end{array}$ \\
\hline Distance to Creek & $\begin{array}{c}5.90^{* * *} \\
(3.03)\end{array}$ & & $\begin{array}{c}6.42^{* * *} \\
(3.42)\end{array}$ & $\begin{array}{l}2.63^{* *} \\
(2.09)\end{array}$ & $\begin{array}{c}5.90^{* * *} \\
(3.11)\end{array}$ & $\begin{array}{c}5.90^{* * *} \\
(3.06)\end{array}$ & $\begin{array}{l}6.25^{\star * *} \\
(3.17)\end{array}$ & $\begin{array}{c}6.07^{* * *} \\
(3.10)\end{array}$ & $\begin{array}{c}5.54^{* * *} \\
(2.73)\end{array}$ & & $\begin{array}{c}4.80^{* * *} \\
(3.15)\end{array}$ \\
\hline Block Corner & $\begin{array}{l}4.38 \\
(0.87)\end{array}$ & & $\begin{array}{c}3.98 \\
(0.82)\end{array}$ & $\begin{array}{l}3.03 \\
(0.67)\end{array}$ & $\begin{array}{l}4.38 \\
(0.77)\end{array}$ & $\begin{array}{c}4.38 \\
(1.59)\end{array}$ & $\begin{array}{c}5.78 \\
(1.13)\end{array}$ & $\begin{array}{l}4.57 \\
(0.91)\end{array}$ & $\begin{array}{l}4.39 \\
(0.87)\end{array}$ & & $\begin{array}{l}8.37^{* *} \\
(2.10)\end{array}$ \\
\hline Distance to Non-Squatted & $3.67^{* *}$ & & $4.51^{* * *}$ & $3.05^{\star}$ & 3.67 & 3.67 & $3.58^{* *}$ & $3.69^{* *}$ & $3.67^{* *}$ & & 2.02 \\
\hline Area & $(2.06)$ & & $(2.60)$ & $(1.93)$ & $(1.60)$ & $(1.43)$ & $(2.01)$ & $(2.07)$ & $(2.06)$ & & $(1.36)$ \\
\hline Age of Original & -1.68 & & & -2.63 & -1.68 & -1.68 & -2.02 & -1.59 & -1.80 & & \\
\hline Squatter $<50$ & $(0.48)$ & & & $(0.88)$ & $(0.51)$ & $(0.51)$ & $(0.58)$ & $(0.45)$ & $(0.51)$ & & \\
\hline Female Original Squatter & -0.70 & & & -1.99 & -0.70 & -0.70 & -0.67 & -0.69 & -0.73 & & \\
\hline Argentine Original & $(0.20)$ & & & $(0.66)$ & $(0.21)$ & $(0.23)$ & $(0.19)$ & $(0.19)$ & $(0.20)$ & & \\
\hline Argentine Original & -7.54 & & & -8.07 & -7.54 & -7.54 & -7.62 & -7.18 & -7.76 & & \\
\hline Squatter & $(0.87)$ & & & $(1.07)$ & $(0.85)$ & $(1.48)$ & $(0.88)$ & $(0.83)$ & $(0.90)$ & & \\
\hline Years of Education of the & -0.08 & & & -0.14 & -0.08 & -0.08 & -0.12 & -0.09 & -0.09 & & \\
\hline Original Squatter & $(0.08)$ & & & $(0.17)$ & $(0.08)$ & $(0.06)$ & $(0.12)$ & $(0.09)$ & $(0.09)$ & & \\
\hline Argentine Father of the & -5.45 & & & -2.43 & -5.45 & -5.45 & -6.05 & -5.68 & -5.28 & & \\
\hline Original Squatter & $(0.79)$ & & & $(0.39)$ & $(0.83)$ & $(1.14)$ & $(0.88)$ & $(0.83)$ & $(0.77)$ & & \\
\hline Years of Education of & $-3.31^{* *}$ & & & $-3.22^{* *}$ & $-3.31^{\star *}$ & $-3.31^{*}$ & $-3.29^{\star \star}$ & $-3.24^{* *}$ & $-3.29^{\star \star}$ & & \\
\hline Original Squatter's Father & $(2.06)$ & & & $(2.38)$ & $(2.21)$ & $(1.89)$ & $(2.05)$ & $(2.01)$ & $(2.04)$ & & \\
\hline Argentine Mother of the & 10.73 & & & 8.19 & 10.73 & $10.73^{\star \star *}$ & 10.92 & 10.54 & 10.51 & & \\
\hline Original Squatter & $(1.55)$ & & & $(1.28)$ & $(1.27)$ & $(3.04)$ & (1.58) & (1.53) & $(1.52)$ & & \\
\hline Years of Educ of Original & $3.59^{* *}$ & & & $3.58^{* *}$ & $3.59^{*}$ & $3.59^{*}$ & $3.50^{* *}$ & $3.54^{* *}$ & $3.57^{* *}$ & & \\
\hline Squatter's Mother & $(2.10)$ & & & $(2.28)$ & $(1.68)$ & $(1.78)$ & $(2.04)$ & $(2.06)$ & $(2.08)$ & & \\
\hline Constant & $\begin{array}{c}54.32^{* * *} \\
(3.98)\end{array}$ & $\begin{array}{c}67.63^{* * *} \\
(26.49)\end{array}$ & $\begin{array}{c}46.28^{\star * *} \\
(5.00)\end{array}$ & $\begin{array}{c}58.62^{* \star \star} \\
(5.32)\end{array}$ & $\begin{array}{c}54.32^{* * *} \\
(3.39)\end{array}$ & $\begin{array}{c}54.32^{* * *} \\
(4.32)\end{array}$ & $\begin{array}{c}52.19^{\star * *} \\
(3.77)\end{array}$ & $\begin{array}{c}52.66^{\star * *} \\
(3.81)\end{array}$ & $\begin{array}{c}55.53^{\star * *} \\
(4.02)\end{array}$ & & $\begin{array}{c}49.97^{\star \star \star} \\
(6.78)\end{array}$ \\
\hline F-stat & & & & & & & & & 0.36 & & \\
\hline Observations & 299 & 299 & 299 & 407 & 299 & 299 & 299 & 299 & 299 & 277 & 447 \\
\hline $\begin{array}{l}\text { Notes: The dependent vari } \\
\text { includes no controls, and } \\
\text { block level are used in Coll } \\
\text { Column (7). The } 2 S L S \text { regr } \\
\text { (9) shows separately the e } \\
\text { estimate using the propens } \\
\text { (for any time of household } \\
* * * \text { significant at } 1 \% \text {. }\end{array}$ & $\begin{array}{l}\text { le is the cc } \\
\text { lumn (3) or } \\
\text { nn (5), and } \\
\text { ssion (instr } \\
\text { ect of early } \\
\text { score of t } \\
\text { rival). The }\end{array}$ & $\begin{array}{l}\text { the former } \\
\text { enting the } \\
\text { d late treat } \\
\text { probability } \\
\text { trol variabl }\end{array}$ & $\begin{array}{l}\text { vner level in } \\
\text { atment vari } \\
\text { ents. The F- } \\
\text { attrition (wit } \\
\text { are describ }\end{array}$ & $\begin{array}{l}\text { neters. The } \\
\text { ristics. Coly } \\
\text { olumn (6). } \\
\text { Property } \\
\text { it tests the } \\
\text { ootstrappe } \\
\text { in Appendi }\end{array}$ & $\begin{array}{l}\text { reduced- } \\
\text { ht with the } \\
\text { II hypothes } \\
\text { standard e } \\
\text { able A.1. }\end{array}$ & $\begin{array}{l}\text { regressio } \\
\text { ention-to-tr } \\
\text { Property } R \\
\text { ). The reg } \\
\text { lute value }\end{array}$ & $\begin{array}{l}\text { on. Colum } \\
\text { for the Sa } \\
n \text { the inten } \\
\text { variable } P \\
\text { t } 1989=P \\
\text { sion in Col } \\
\text { t statistics }\end{array}$ & $\begin{array}{l}\text {-to-treat v } \\
\text { erty Right } \\
\text { erty Right } \\
n(11) \text { is e } \\
\text { arenthese }\end{array}$ & $\begin{array}{l}\text { d in Colu } \\
\text { hood. Sta } \\
\text { ble Prope } \\
\text { r) is pres } \\
\text { 8. Colum } \\
\text { ated on a } \\
\text { Significan }\end{array}$ & $\begin{array}{l}\text { of Tabl } \\
\text { errors } \\
\text { ght Offe } \\
\text { in Colu } \\
\text { presen } \\
\text { interviev } \\
0 \% ;{ }^{* *} s\end{array}$ & $\begin{array}{l}\text { Column (2) } \\
\text { ered at the } \\
\text { isplayed in } \\
\text { 8). Column } \\
\text { matching } \\
\text { ouseholds } \\
\text { cant at } 5 \% \text {; }\end{array}$ \\
\hline
\end{tabular}




\begin{tabular}{|c|c|c|c|c|c|c|c|c|c|c|c|}
\hline \multicolumn{12}{|c|}{ Appendix Table A.3 - CONCRETE SIDEWALK } \\
\hline \multirow[b]{2}{*}{ Property Right } & $(1)$ & $(2)$ & (3) & $(4)$ & $(5)$ & $(6)$ & $(7)$ & $(8)$ & (9) & $(10)$ & $(11)$ \\
\hline & $\begin{array}{l}0.11^{\star *} \\
(2.18)\end{array}$ & $\begin{array}{c}0.08 \\
(1.43)\end{array}$ & $\begin{array}{l}0.12^{\star *} \\
(2.24)\end{array}$ & $\begin{array}{l}0.10^{\star \star} \\
(2.41)\end{array}$ & $\begin{array}{c}0.11 \\
(1.60)\end{array}$ & $\begin{array}{c}0.11 \\
(1.55)\end{array}$ & & $\begin{array}{c}0.10 \\
(1.63)\end{array}$ & & $\begin{array}{c}0.08 \\
(1.42)\end{array}$ & $\begin{array}{c}0.16^{* \star \star} \\
(3.85)\end{array}$ \\
\hline Property Right Offer & & & & & & & $\begin{array}{c}0.09 \\
(1.62)\end{array}$ & & & & \\
\hline Property Right 1989 & & & & & & & & & $\begin{array}{l}0.16^{\star *} \\
(2.14)\end{array}$ & & \\
\hline Property Right 1998 & & & & & & & & & $\begin{array}{c}0.09 \\
(1.55)\end{array}$ & & \\
\hline Parcel Surface & $\begin{array}{l}-0.00 \\
(0.44)\end{array}$ & & $\begin{array}{l}-0.00 \\
(0.69)\end{array}$ & $\begin{array}{l}-0.00 \\
(0.51)\end{array}$ & $\begin{array}{l}-0.00 \\
(0.40)\end{array}$ & $\begin{array}{l}-0.00 \\
(0.24)\end{array}$ & $\begin{array}{l}-0.00 \\
(0.33)\end{array}$ & $\begin{array}{l}-0.00 \\
(0.47)\end{array}$ & $\begin{array}{l}-0.00 \\
(0.46)\end{array}$ & & $\begin{array}{c}-0.00 \\
(1.15)\end{array}$ \\
\hline Distance to Creek & $\begin{array}{c}0.09^{\star \star *} \\
(3.29)\end{array}$ & & $\begin{array}{c}0.09^{* * *} \\
(3.19)\end{array}$ & $\begin{array}{c}0.08^{\star \star \star} \\
(4.64)\end{array}$ & $\begin{array}{l}0.09^{\star *} \\
(2.40)\end{array}$ & $\begin{array}{l}0.09^{\star \star} \\
(2.25)\end{array}$ & $\begin{array}{c}0.09^{\star * *} \\
(3.25)\end{array}$ & $\begin{array}{c}0.09^{\star \star \star *} \\
(3.22)\end{array}$ & $\begin{array}{c}0.09^{\star \star *} \\
(2.90)\end{array}$ & & $\begin{array}{c}0.11^{\star \star *} \\
(4.89)\end{array}$ \\
\hline Block Corner & $\begin{array}{l}-0.12 \\
(1.57)\end{array}$ & & $\begin{array}{c}-0.14^{\star *} \\
(1.98)\end{array}$ & $\begin{array}{c}-0.13^{* *} \\
(2.17)\end{array}$ & $\begin{array}{l}-0.12 \\
(1.65)\end{array}$ & $\begin{array}{l}-0.12^{*} \\
(2.01)\end{array}$ & $\begin{array}{l}-0.11 \\
(1.38)\end{array}$ & $\begin{array}{l}-0.12 \\
(1.59)\end{array}$ & $\begin{array}{l}-0.12 \\
(1.57)\end{array}$ & & $\begin{array}{l}-0.08 \\
(1.29)\end{array}$ \\
\hline Distance to Non-Squatted & $-0.07^{\star *}$ & & $-0.07^{\star * \star}$ & $-0.05^{\star *}$ & $-0.07^{*}$ & -0.07 & $-0.07^{* *}$ & $-0.07^{* *}$ & $-0.07^{\star *}$ & & $-0.09^{* * *}$ \\
\hline Area & (2.49) & & $(2.66)$ & $(2.27)$ & $(1.68)$ & $(1.69)$ & $(2.50)$ & (2.49) & $(2.49)$ & & $(4.14)$ \\
\hline Age of Original & $-0.10^{*}$ & & & $-0.07^{*}$ & $-0.10^{* \star}$ & $-0.10^{*}$ & $-0.11^{* *}$ & $-0.10^{*}$ & $-0.10^{*}$ & & \\
\hline Squatter $<50$ & $(1.92)$ & & & $(1.78)$ & $(2.03)$ & (2.09) & $(2.02)$ & $(1.94)$ & $(1.97)$ & & \\
\hline Female Original Squatter & -0.05 & & & -0.06 & -0.05 & -0.05 & -0.05 & -0.05 & -0.05 & & \\
\hline & $(0.95)$ & & & $(1.54)$ & $(0.90)$ & $(1.45)$ & $(0.95)$ & $(0.96)$ & $(0.97)$ & & \\
\hline Argentine Original & 0.06 & & & 0.05 & 0.06 & 0.06 & 0.06 & 0.06 & 0.06 & & \\
\hline Squatter & $(0.50)$ & & & $(0.47)$ & $(0.41)$ & $(0.74)$ & $(0.45)$ & $(0.48)$ & $(0.47)$ & & \\
\hline Years of Education of the & -0.02 & & & -0.02 & $-0.02^{*}$ & $-0.02^{* \star}$ & -0.02 & -0.02 & -0.02 & & \\
\hline Original Squatter & $(1.44)$ & & & $(1.50)$ & $(1.81)$ & $(2.75)$ & $(1.45)$ & $(1.43)$ & $(1.46)$ & & \\
\hline Argentine Father of the & -0.03 & & & -0.02 & -0.03 & -0.03 & -0.04 & -0.03 & -0.03 & & \\
\hline Original Squatter & $(0.34)$ & & & $(0.19)$ & $(0.40)$ & $(0.32)$ & $(0.36)$ & $(0.32)$ & $(0.30)$ & & \\
\hline Years of Education of & 0.03 & & & 0.03 & 0.03 & $0.03^{*}$ & 0.03 & 0.03 & 0.03 & & \\
\hline Original Squatter's Father & $(1.37)$ & & & $(1.48)$ & $(1.55)$ & $(1.74)$ & $(1.33)$ & $(1.34)$ & (1.39) & & \\
\hline Argentine Mother of the & -0.02 & & & -0.03 & -0.02 & -0.02 & -0.02 & -0.02 & -0.03 & & \\
\hline Original Squatter & $(0.21)$ & & & $(0.34)$ & $(0.15)$ & $(0.23)$ & $(0.16)$ & $(0.19)$ & $(0.25)$ & & \\
\hline Years of Educ of Original & -0.03 & & & -0.03 & -0.03 & -0.03 & -0.03 & -0.03 & -0.03 & & \\
\hline Squatter's Mother & $(1.15)$ & & & $(1.35)$ & $(1.11)$ & $(0.99)$ & $(1.17)$ & $(1.14)$ & $(1.17)$ & & \\
\hline Constant & $\begin{array}{c}0.84^{* * *} \\
(4.10)\end{array}$ & $\begin{array}{l}0.67^{* * *} \\
(17.19)\end{array}$ & $\begin{array}{c}0.71^{* * *} \\
(5.17)\end{array}$ & $\begin{array}{c}0.81^{* * *} \\
(5.54)\end{array}$ & $\begin{array}{c}0.84^{* * *} \\
(3.27)\end{array}$ & $\begin{array}{l}0.84^{* *} \\
(2.26)\end{array}$ & $\begin{array}{c}0.84^{* * *} \\
(4.06)\end{array}$ & $\begin{array}{c}0.85^{\star \star *} \\
(4.13)\end{array}$ & $\begin{array}{c}0.86^{* * *} \\
(4.18)\end{array}$ & & $\begin{array}{c}0.68^{\star * *} \\
(6.34)\end{array}$ \\
\hline F-stat & & & & & & & & & 0.71 & & \\
\hline Observations & 300 & 300 & 300 & 408 & 300 & 300 & 300 & 300 & 300 & 278 & 448 \\
\hline $\begin{array}{l}\text { Notes: The dependent va } \\
\text { summarized in Column } 4 \\
\text { neighborhood. Standard e } \\
\text { treat variable Property Rig } \\
\text { Right Offer) is presented } \\
\text { Right } 1998 \text {. Column (10) p } \\
\text { is estimated on all the int } \\
\text { parentheses. }{ }^{*} \text { Significant }\end{array}$ & $\begin{array}{l}\text { ofs cluster } \\
\text { Offer is di } \\
\text { olumn ( } 8 \\
\text { ents the } \\
\text { iewed ho } \\
10 \% ;{ }^{* *} \text { si }\end{array}$ & $\begin{array}{l}\text { Ty that eq } \\
\text { nn (2) incl } \\
\text { t the block } \\
\text { yed in Col } \\
\text { olumn (9) } \\
\text { thing estin } \\
\text { holds (for } \\
\text { cant at } 5 \%\end{array}$ & $\begin{array}{l}\text { (7). The } \\
\text { vs separa } \\
\text { using the } \\
\text { time of } h \\
\text { significan }\end{array}$ & $\begin{array}{l}\text { regress } \\
\text { he effect } \\
\text { ensity sc } \\
\text { hold arri } \\
\% \text {. }\end{array}$ & $\begin{array}{l}\text { nstrumen } \\
\text { arly and I } \\
\text { f the prob } \\
\text { The cont }\end{array}$ & $\begin{array}{l}\text { ariables } \\
\text { ty of attrit } \\
\text { a }\end{array}$ & $\begin{array}{l}\text { naracterist } \\
\text { el in Colu } \\
\text { variable } \\
\text { ne-stat } \\
\text { (with boot } \\
\text { described }\end{array}$ & $\begin{array}{l}\text { the null } \\
\text { ped stan } \\
\text { ppendix }\end{array}$ & $\begin{array}{l}\text { d-form } \\
\text { the inter } \\
\text { hesis: P } \\
\text { errors). } \\
\text { A.1. A }\end{array}$ & $\begin{array}{l}\text { ervation } \\
\text { tions for } \\
\text { sion on } \\
\text {-treat ve } \\
\text { Right } 1 \\
\text { gression } \\
\text { value }\end{array}$ & $\begin{array}{l}\text { lumn (1) i } \\
\text { San Martii } \\
\text { tention-to } \\
\text { le Propert } \\
=\text { Propert } \\
\text { olumn (11 } \\
\text { statistics it }\end{array}$ \\
\hline
\end{tabular}




\begin{tabular}{|c|c|c|c|c|c|c|c|c|c|c|c|}
\hline \multicolumn{12}{|c|}{ Appendix Table A.4 - OVERALL HOUSING APPEARANCE } \\
\hline \multirow[b]{2}{*}{ Property Right } & $(1)$ & $(2)$ & $(3)$ & $(4)$ & $(5)$ & $(6)$ & $(7)$ & $(8)$ & (9) & $(10)$ & $(11)$ \\
\hline & $\begin{array}{l}8.42^{\star \star *} \\
(3.65)\end{array}$ & $\begin{array}{c}7.45^{\star * *} \\
(3.38)\end{array}$ & $\begin{array}{c}8.07^{\star * *} \\
(3.58)\end{array}$ & $\begin{array}{l}5.39^{\star \star *} \\
(2.67)\end{array}$ & $\begin{array}{l}8.42^{* * *} \\
(3.91)\end{array}$ & $\begin{array}{l}8.42^{\star * *} \\
(2.98)\end{array}$ & & $\begin{array}{c}10.17^{* * *} \\
(3.80)\end{array}$ & & $\begin{array}{c}8.23^{* * *} \\
(3.63)\end{array}$ & $\begin{array}{l}6.97^{* * *} \\
(3.87)\end{array}$ \\
\hline Property Right Offer & & & & & & & $\begin{array}{c}9.34^{* * *} \\
(3.81)\end{array}$ & & & & \\
\hline Property Right 1989 & & & & & & & & & $\begin{array}{l}6.27^{*} \\
(1.95)\end{array}$ & & \\
\hline Property Right 1998 & & & & & & & & & $\begin{array}{l}9.54^{* * *} \\
(3.68)\end{array}$ & & \\
\hline Parcel Surface & $\begin{array}{l}-0.02 \\
(1.28)\end{array}$ & & $\begin{array}{l}-0.02 \\
(1.46)\end{array}$ & $\begin{array}{l}-0.00 \\
(0.47)\end{array}$ & $\begin{array}{l}-0.02 \\
(1.49)\end{array}$ & $\begin{array}{l}-0.02^{*} \\
(2.00)\end{array}$ & $\begin{array}{l}-0.01 \\
(0.89)\end{array}$ & $\begin{array}{l}-0.02 \\
(1.19)\end{array}$ & $\begin{array}{l}-0.02 \\
(1.25)\end{array}$ & & $\begin{array}{l}-0.02^{*} \\
(1.87)\end{array}$ \\
\hline Distance to Creek & $\begin{array}{l}2.47^{\star} \\
(1.95)\end{array}$ & & $\begin{array}{l}2.32^{\star} \\
(1.90)\end{array}$ & $\begin{array}{l}-0.26 \\
(0.32)\end{array}$ & $\begin{array}{l}2.47^{*} \\
(1.85)\end{array}$ & $\begin{array}{l}2.47^{* *} \\
(2.88)\end{array}$ & $\begin{array}{l}2.84^{* *} \\
(2.21)\end{array}$ & $\begin{array}{l}2.66^{* *} \\
(2.08)\end{array}$ & $\begin{array}{l}2.83^{* *} \\
(2.14)\end{array}$ & & $\begin{array}{c}3.01^{* * *} \\
(3.13)\end{array}$ \\
\hline Block Corner & $\begin{array}{c}0.13 \\
(0.04)\end{array}$ & & $\begin{array}{l}-0.70 \\
(0.22)\end{array}$ & $\begin{array}{c}1.94 \\
(0.68)\end{array}$ & $\begin{array}{c}0.13 \\
(0.04)\end{array}$ & $\begin{array}{c}0.13 \\
(0.03)\end{array}$ & $\begin{array}{c}1.59 \\
(0.48)\end{array}$ & $\begin{array}{c}0.34 \\
(0.10)\end{array}$ & $\begin{array}{c}0.13 \\
(0.04)\end{array}$ & & $\begin{array}{c}0.02 \\
(0.01)\end{array}$ \\
\hline Distance to Non-Squatted & -0.00 & & -0.14 & -0.19 & -0.00 & -0.00 & -0.09 & 0.02 & -0.01 & & -0.49 \\
\hline Area & $(0.00)$ & & $(0.13)$ & $(0.18)$ & $(0.00)$ & $(0.00)$ & $(0.08)$ & $(0.02)$ & $(0.01)$ & & $(0.52)$ \\
\hline Age of Original & 0.61 & & & 0.12 & 0.61 & 0.61 & 0.26 & 0.71 & 0.73 & & \\
\hline Squatter $<50$ & $(0.26)$ & & & $(0.06)$ & $(0.31)$ & $(0.43)$ & $(0.11)$ & $(0.31)$ & $(0.32)$ & & \\
\hline Female Original Squatter & $\begin{array}{l}-3.21 \\
(1.39)\end{array}$ & & & $\begin{array}{c}-3.98^{\star \star} \\
(2.08)\end{array}$ & $\begin{array}{l}-3.21 \\
(1.46)\end{array}$ & $\begin{array}{l}-3.21 \\
(1.71)\end{array}$ & $\begin{array}{l}-3.18 \\
(1.38)\end{array}$ & $\begin{array}{l}-3.20 \\
(1.38)\end{array}$ & $\begin{array}{l}-3.18 \\
(1.37)\end{array}$ & & \\
\hline Argentine Original & 6.82 & & & 2.65 & 6.82 & $6.82^{* *}$ & 6.77 & 7.22 & 7.04 & & \\
\hline Squatter & $(1.21)$ & & & $(0.55)$ & $(0.95)$ & (2.33) & $(1.20)$ & $(1.28)$ & $(1.25)$ & & \\
\hline Years of Education of the & 0.70 & & & 0.48 & 0.70 & 0.70 & 0.66 & 0.69 & 0.72 & & \\
\hline Original Squatter & $(1.08)$ & & & $(0.93)$ & $(0.88)$ & $(0.73)$ & $(1.02)$ & $(1.06)$ & $(1.11)$ & & \\
\hline Argentine Father of the & $-9.82^{* *}$ & & & -5.85 & $-9.82^{* *}$ & $-9.82^{* *}$ & $-10.46^{* *}$ & $-10.07^{* *}$ & $-9.99^{* \star}$ & & \\
\hline Original Squatter & $(2.19)$ & & & $(1.45)$ & $(2.20)$ & $(2.40)$ & $(2.34)$ & $(2.25)$ & $(2.23)$ & & \\
\hline Years of Education of & -1.13 & & & -0.65 & -1.13 & $-1.13^{* *}$ & -1.10 & -1.05 & -1.16 & & \\
\hline Original Squatter's Father & $(1.08)$ & & & $(0.75)$ & $(1.37)$ & $(2.17)$ & $(1.05)$ & $(1.00)$ & $(1.10)$ & & \\
\hline Argentine Mother of the & -1.94 & & & -1.18 & -1.94 & -1.94 & -1.75 & -2.14 & -1.71 & & \\
\hline Original Squatter & $(0.43)$ & & & $(0.29)$ & $(0.33)$ & $(0.45)$ & $(0.39$ & $(0.47)$ & $(0.38)$ & & \\
\hline Years of Educ of Original & -1.22 & & & -0.81 & -1.22 & -1.22 & -1.32 & -1.28 & -1.19 & & \\
\hline Squatter's Mother & $(1.09)$ & & & $(0.81)$ & $(1.00)$ & $(0.97)$ & $(1.18)$ & $(1.14)$ & $(1.07)$ & & \\
\hline Constant & $\begin{array}{c}34.15^{\star * *} \\
(3.84)\end{array}$ & $\begin{array}{c}22.71^{* * *} \\
(13.82)\end{array}$ & $\begin{array}{c}24.63^{\star \star *} \\
(4.08)\end{array}$ & $\begin{array}{c}33.20^{\star \star \star} \\
(4.72)\end{array}$ & $\begin{array}{c}34.15^{\star \star *} \\
(3.71)\end{array}$ & $\begin{array}{c}34.15^{\star \star \star} \\
(3.89)\end{array}$ & $\begin{array}{c}31.85^{\star \star *} \\
(3.53)\end{array}$ & $\begin{array}{c}32.33^{\star \star *} \\
(3.58)\end{array}$ & $\begin{array}{c}32.89^{\star \star *} \\
(3.66)\end{array}$ & & $\begin{array}{c}24.73^{\star \star \star} \\
(5.31)\end{array}$ \\
\hline F-stat & & & & & & & & & 0.91 & & \\
\hline Observations & 299 & 299 & 299 & 407 & 299 & 299 & 299 & 299 & 299 & 277 & 446 \\
\hline $\begin{array}{l}\text { Notes: The dependent var } \\
\text { town of Solano and } 100 \mathrm{fo} \\
\text { overall aspect of each hou } \\
\text { summarized in Column } 5 \\
\text { neighborhood. Standard e } \\
\text { treat variable Property Rig } \\
\text { Right Offer) is presented } \\
\text { Right } 1998 \text {. Column (10) p } \\
\text { is estimated on all the int } \\
\text { parentheses. }{ }^{*} \text { Significant }\end{array}$ & $\begin{array}{l}\text { Table 3. Cc } \\
\text { rs clustere } \\
\text { Offer is dis } \\
\text { Column (8) } \\
\text { sents the } \mathrm{m} \\
\text { vewed hou } \\
10 \% \text {; }{ }^{* *} \text { sig }\end{array}$ & $\begin{array}{l}\text { nn (2) inclu } \\
t \text { the block } \\
\text { yed in Colu } \\
\text { olumn (9) s } \\
\text { ching estima } \\
\text { holds (for a } \\
\text { cant at } 5 \% \text {; }\end{array}$ & $\begin{array}{l}\text { no contro } \\
\text { l are usec } \\
\text { (7). The } 2 \\
\text { vs separat } \\
\text { using the p } \\
\text { time of ho } \\
\text { significant }\end{array}$ & $\begin{array}{l}\text { and Colum } \\
\text { Column } \\
\text { S regressi } \\
\text { the effect } \\
\text { pensity scc } \\
\text { ehold arriv } \\
1 \% \text {. }\end{array}$ & $\begin{array}{l}\text { 3) only con } \\
\text { and at the } \\
\text { instrument } \\
\text { arly and la } \\
\text { f the prob } \\
\text { The contr }\end{array}$ & $\begin{array}{l}\text { s for parce } \\
\text { ner owner } \\
\text { the treatm } \\
\text { treatments } \\
\text { ity of attriti } \\
\text { ariables a }\end{array}$ & $\begin{array}{l}\text { variable } \\
\text { he F-stat } \\
\text { (with boot } \\
\text { described }\end{array}$ & $\begin{array}{l}\text { Column (4 } \\
\text { 6). The re } \\
\text { rity Right } \\
\text { the null h } \\
\text { ped stand } \\
\text { ppendix T }\end{array}$ & $\begin{array}{l}\text { ds the obs } \\
\text { ed-form re } \\
\text { the intent } \\
\text { thesis: Pro } \\
\text { errors). Th } \\
\text { A.1. Abs }\end{array}$ & $\begin{array}{l}\text { servation } \\
\text { ations for } \\
\text { sion on t } \\
\text { o-treat va } \\
\text { y Right } 1 \\
\text { gression } \\
\text { e value co }\end{array}$ & $\begin{array}{l}\text { in a shanty } \\
\text { asures the } \\
\text { plumn (1) is } \\
\text { San Martin } \\
\text { tention-to- } \\
\text { le Property } \\
=\text { Property } \\
\text { olumn (11) } \\
\text { statistics in }\end{array}$ \\
\hline
\end{tabular}




\begin{tabular}{|c|c|c|c|c|c|}
\hline \multicolumn{6}{|c|}{ Appendix Table A.5 - DURABLE CONSUMPTION } \\
\hline \multirow[b]{3}{*}{ Property Right } & $\begin{array}{l}\text { Refrigerator } \\
\text { with } \\
\text { Freezer }\end{array}$ & $\begin{array}{l}\text { Refrigerator } \\
\text { without } \\
\text { Freezer }\end{array}$ & $\begin{array}{l}\text { Washing } \\
\text { Machine }\end{array}$ & TV & $\begin{array}{l}\text { Cellular } \\
\text { Phone }\end{array}$ \\
\hline & $(1)$ & $(2)$ & (3) & $(4)$ & (5) \\
\hline & 0.05 & 0.04 & 0.04 & -0.01 & -0.01 \\
\hline & $(0.92)$ & $(0.61)$ & $(0.67)$ & $(0.40)$ & $(0.32)$ \\
\hline \multirow[t]{2}{*}{ Parcel Surface } & -0.00 & 0.00 & 0.00 & -0.00 & 0.00 \\
\hline & $(1.28)$ & $(0.82)$ & $(0.39)$ & $(0.44)$ & $(0.98)$ \\
\hline \multirow[t]{2}{*}{ Distance to Creek } & $0.09^{* * *}$ & -0.03 & $0.06^{* *}$ & $0.06^{* * *}$ & $0.03^{*}$ \\
\hline & $(2.98)$ & $(0.83)$ & $(2.11)$ & $(3.12)$ & $(1.88)$ \\
\hline \multirow[t]{2}{*}{ Block Corner } & -0.04 & 0.09 & 0.05 & 0.03 & 0.02 \\
\hline & $(0.47)$ & $(1.05)$ & $(0.56)$ & $(0.67)$ & $(0.57)$ \\
\hline \multirow[t]{2}{*}{ Distance to Non-Squatted Area } & -0.01 & 0.02 & $0.06^{* *}$ & 0.02 & 0.00 \\
\hline & $(0.28)$ & $(0.80)$ & $(2.04)$ & $(0.95)$ & $(0.31)$ \\
\hline \multirow[t]{2}{*}{ Age of Original Squatter $<50$} & 0.03 & -0.01 & 0.02 & 0.01 & -0.01 \\
\hline & $(0.58)$ & $(0.20)$ & $(0.32)$ & $(0.38)$ & $(0.32)$ \\
\hline Female Original Squatter & $\begin{array}{c}0.02 \\
(0.35)\end{array}$ & $\begin{array}{l}-0.04 \\
(0.74)\end{array}$ & $\begin{array}{l}-0.05 \\
(0.86)\end{array}$ & $\begin{array}{c}0.03 \\
(1.04)\end{array}$ & $\begin{array}{c}0.00 \\
(0.20)\end{array}$ \\
\hline Argentine Original Squatter & $\begin{array}{c}0.05 \\
(0.37)\end{array}$ & $\begin{array}{l}-0.06 \\
(0.37)\end{array}$ & $\begin{array}{l}-0.02 \\
(0.14)\end{array}$ & $\begin{array}{c}-0.22^{* \star *} \\
(2.67)\end{array}$ & $\begin{array}{l}-0.01 \\
(0.22)\end{array}$ \\
\hline Years of Education of the & 0.02 & -0.02 & 0.02 & 0.01 & -0.00 \\
\hline Original Squatter & $(1.02)$ & $(1.29)$ & $(1.30)$ & $(1.55)$ & $(0.64)$ \\
\hline Argentine Father of the & -0.10 & 0.05 & -0.04 & 0.06 & 0.04 \\
\hline Original Squatter & $(0.87)$ & $(0.43)$ & $(0.39)$ & $(0.90)$ & $(0.90)$ \\
\hline Years of Education of & 0.01 & 0.01 & -0.01 & -0.00 & $0.02^{*}$ \\
\hline Original Squatter's Father & $(0.21)$ & $(0.18)$ & $(0.54)$ & $(0.14)$ & $(1.91)$ \\
\hline Argentine Mother of the & -0.03 & 0.06 & -0.07 & 0.08 & -0.02 \\
\hline Original Squatter & $(0.30)$ & $(0.50)$ & $(0.62)$ & $(1.18)$ & $(0.49)$ \\
\hline Years of Education of & 0.01 & -0.01 & $-0.05^{*}$ & -0.01 & $-0.02^{* *}$ \\
\hline Original Squatter's Mother & $(0.35)$ & $(0.38)$ & $(1.77)$ & $(0.82)$ & $(2.06)$ \\
\hline Constant & 0.19 & $0.55^{\star *}$ & $0.66^{* * *}$ & $0.85^{* * *}$ & -0.01 \\
\hline & $(0.86)$ & $(2.33)$ & $(3.02)$ & $(6.64)$ & $(0.12)$ \\
\hline Observations & 311 & 311 & 311 & 312 & 312 \\
\hline $\begin{array}{l}\text { Notes: The dependent variable } \\
\text { good, and } 0 \text { otherwise. The hou } \\
\text { Appendix Table A. } 1 \text {. Absolute } \\
5 \% ;{ }^{* *} \text { significant at } 1 \% \text {. }\end{array}$ & ch column is & a dummy that & $\begin{array}{l}\text { Tuals } 1 \text { if } t \\
\text { The contr } \\
\text { * Signific }\end{array}$ & $\begin{array}{l}\text { Dusehold } \\
\text { riables at } \\
\text { at } 10 \% \text {; }\end{array}$ & $\begin{array}{l}\text { esses the } \\
\text { scribed ir } \\
\text { nificant a }\end{array}$ \\
\hline
\end{tabular}




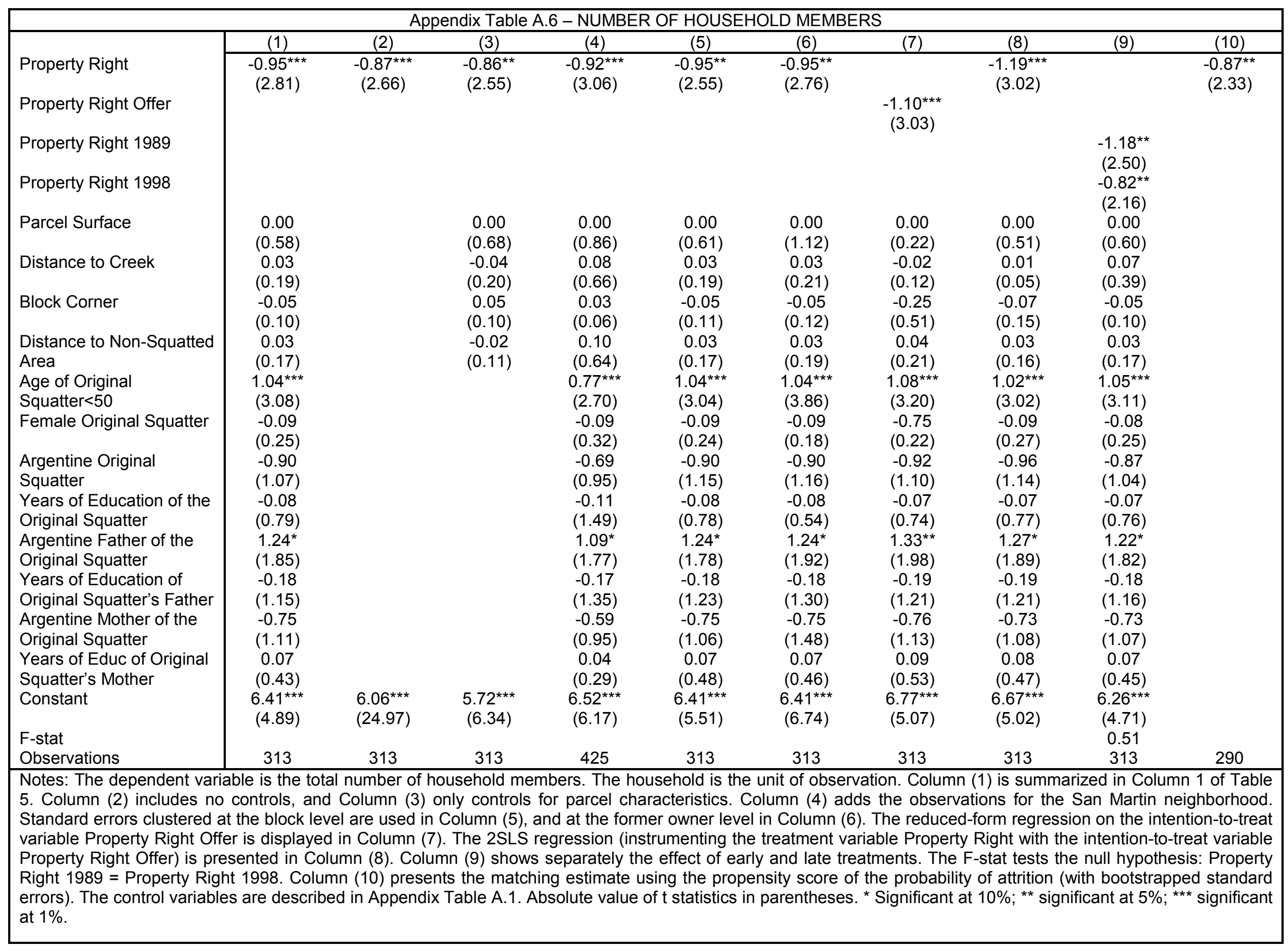




\begin{tabular}{|c|c|c|c|c|c|c|c|c|c|c|}
\hline \multicolumn{11}{|c|}{ Appendix Table A.7 - HOUSEHOLD HEAD SPOUSE } \\
\hline \multirow[b]{2}{*}{ Property Right } & $(1)$ & $(2)$ & $(3)$ & $(4)$ & $(5)$ & $(6)$ & $(7)$ & $(8)$ & (9) & $(10)$ \\
\hline & $\begin{array}{l}-0.01 \\
(0.27)\end{array}$ & $\begin{array}{l}-0.02 \\
(0.37)\end{array}$ & $\begin{array}{l}-0.02 \\
(0.37)\end{array}$ & $\begin{array}{l}-0.03 \\
(0.56)\end{array}$ & $\begin{array}{l}-0.01 \\
(0.26)\end{array}$ & $\begin{array}{l}-0.01 \\
(0.41)\end{array}$ & & $\begin{array}{c}0.01 \\
(0.20)\end{array}$ & & $\begin{array}{l}-0.05 \\
(0.70)\end{array}$ \\
\hline Property Right Offer & & & & & & & $\begin{array}{c}0.01 \\
(0.20)\end{array}$ & & & \\
\hline Property Right 1989 & & & & & & & & & $\begin{array}{l}-0.03 \\
(0.36)\end{array}$ & \\
\hline Property Right 1998 & & & & & & & & & $\begin{array}{l}-0.01 \\
(0.13)\end{array}$ & \\
\hline Parcel Surface & $\begin{array}{l}-0.00 \\
(0.94)\end{array}$ & & $\begin{array}{l}-0.00 \\
(1.45)\end{array}$ & $\begin{array}{l}-0.00 \\
(0.86)\end{array}$ & $\begin{array}{l}-0.00 \\
(0.98)\end{array}$ & $\begin{array}{l}-0.00 \\
(1.53)\end{array}$ & $\begin{array}{l}-0.00 \\
(0.86)\end{array}$ & $\begin{array}{l}-0.00 \\
(0.89)\end{array}$ & $\begin{array}{l}-0.00 \\
(0.93)\end{array}$ & \\
\hline Distance to Creek & $\begin{array}{c}0.02 \\
(0.67)\end{array}$ & & $\begin{array}{c}0.01 \\
(0.47)\end{array}$ & $\begin{array}{c}0.01 \\
(0.73)\end{array}$ & $\begin{array}{c}0.02 \\
(0.70)\end{array}$ & $\begin{array}{c}0.02 \\
(0.58)\end{array}$ & $\begin{array}{c}0.02 \\
(0.75)\end{array}$ & $\begin{array}{c}0.02 \\
(0.75)\end{array}$ & $\begin{array}{c}0.02 \\
(0.70)\end{array}$ & \\
\hline Block Corner & $\begin{array}{l}0.03 \\
(0.41)\end{array}$ & & $\begin{array}{c}0.06 \\
(0.84)\end{array}$ & $\begin{array}{l}0.03 \\
(0.44)\end{array}$ & $\begin{array}{l}0.03 \\
(0.44)\end{array}$ & $\begin{array}{c}0.03 \\
(0.45)\end{array}$ & $\begin{array}{l}0.03 \\
(0.46)\end{array}$ & $\begin{array}{l}0.03 \\
(0.45)\end{array}$ & $\begin{array}{l}0.03 \\
(0.41)\end{array}$ & \\
\hline Distance to Non-Squatted & 0.01 & & 0.00 & 0.03 & 0.01 & 0.01 & 0.01 & 0.01 & 0.01 & \\
\hline Area & $(0.37)$ & & $(0.03)$ & $(1.22)$ & $(0.36)$ & $(0.39)$ & $(0.37)$ & $(0.37)$ & $(0.37)$ & \\
\hline Age of Original & 0.03 & & & 0.04 & 0.03 & 0.03 & 0.03 & 0.03 & 0.03 & \\
\hline Squatter $<50$ & $(0.56)$ & & & $(1.02)$ & $(0.47)$ & $(0.57)$ & $(0.58)$ & $(0.59)$ & $(0.57)$ & \\
\hline Female Original Squatter & $\begin{array}{c}-0.28^{\star * *} \\
(5.41)\end{array}$ & & & $\begin{array}{c}-0.31^{* * *} \\
(7.20)\end{array}$ & $\begin{array}{c}-0.28^{* * *} \\
(4.82)\end{array}$ & $\begin{array}{c}-0.28^{* * *} \\
(4.66)\end{array}$ & $\begin{array}{c}-0.28^{* * *} \\
(5.40)\end{array}$ & $\begin{array}{c}-0.28^{* * *} \\
(5.39)\end{array}$ & $\begin{array}{c}-0.28^{* * *} \\
(5.40)\end{array}$ & \\
\hline Argentine Original & -0.01 & & & 0.01 & -0.01 & -0.01 & -0.00 & 0.00 & -0.00 & \\
\hline Squatter & $(0.05)$ & & & $(0.14)$ & $(0.05)$ & $(0.04)$ & $(0.00)$ & $(0.00)$ & $(0.04)$ & \\
\hline Years of Education of the & $0.02^{*}$ & & & 0.01 & $0.02^{*}$ & $0.02^{* *}$ & $0.02^{*}$ & $0.02^{*}$ & $0.02^{*}$ & \\
\hline Original Squatter & $(1.71)$ & & & $(1.02)$ & $(1.77)$ & $(2.22)$ & $(1.70)$ & $(1.71)$ & $(1.72)$ & \\
\hline Argentine Father of the & -0.05 & & & -0.02 & -0.05 & -0.05 & -0.05 & -0.05 & -0.05 & \\
\hline Original Squatter & $(0.45)$ & & & $(0.24)$ & $(0.55)$ & $(0.77)$ & $(0.48)$ & $(0.48)$ & $(0.45)$ & \\
\hline Years of Education of & 0.00 & & & 0.02 & 0.00 & 0.00 & 0.00 & 0.00 & 0.00 & \\
\hline Original Squatter's Father & $(0.03)$ & & & $(0.85)$ & $(0.03)$ & $(0.03)$ & $(0.07)$ & $(0.07)$ & $(0.02)$ & \\
\hline Argentine Mother of the & -0.06 & & & -0.09 & -0.06 & -0.06 & -0.06 & -0.06 & -0.06 & \\
\hline Original Squatter & $(0.58)$ & & & $(0.93)$ & $(0.63)$ & $(0.53)$ & $(0.60)$ & $(0.60)$ & $(0.56)$ & \\
\hline Years of Educ of Original & -0.02 & & & 0.00 & -0.02 & -0.02 & -0.02 & -0.02 & -0.02 & \\
\hline Squatter's Mother & $(0.81)$ & & & $(0.12)$ & $(0.64)$ & $(0.85)$ & $(0.84)$ & $(0.83)$ & $(0.80)$ & \\
\hline & $\begin{array}{c}0.89^{* * *} \\
(4.46)\end{array}$ & $\begin{array}{l}0.74^{* * *} \\
(19.44)\end{array}$ & $\begin{array}{c}0.84^{\star * *} \\
(6.01)\end{array}$ & $\begin{array}{c}0.73^{* * *} \\
(4.59)\end{array}$ & $\begin{array}{c}0.89^{* * *} \\
(5.25)\end{array}$ & $\begin{array}{c}0.89^{* * *} \\
(9.38)\end{array}$ & $\begin{array}{c}0.86^{* * *} \\
(4.23)\end{array}$ & $\begin{array}{c}0.86^{* * *} \\
(4.27)\end{array}$ & $\begin{array}{c}0.88^{* * *} \\
(4.36)\end{array}$ & \\
\hline F-stat & & & & & & & & & 0.06 & \\
\hline Observations & 313 & 313 & 313 & 425 & 313 & 313 & 313 & 313 & 313 & 290 \\
\hline $\begin{array}{l}\text { Notes: The dependent vari } \\
\text { (1) is summarized in Colun } \\
\text { for the San Martin neighbo } \\
\text { regression on the intention } \\
\text { with the intention-to-treat } \\
\text { tests the null hypothesis: } \\
\text { attrition (with bootstrapped } \\
10 \% \text {; }{ }^{* *} \text { significant at } 5 \% \text {; }\end{array}$ & $\begin{array}{l}\text { e is a dun } \\
2 \text { of Table } \\
\text { od. Stan } \\
\text { treat vari } \\
\text { able Prop } \\
\text { perty Rig } \\
\text { andard en } \\
\text { ignificant }\end{array}$ & $\begin{array}{l}\text { that equa } \\
\text { Column }(2 \\
\text { errors clu } \\
\text { Property } \\
\text { Right Off } \\
989=\text { Pro } \\
\text {. The cor } \\
\% \text {. }\end{array}$ & $\begin{array}{l}\text { the hous } \\
\text { udes no } \\
\mathrm{d} \text { at the } \\
\text { Offer is } \\
\text { present } \\
\text { Right } 1 \\
\text { ariables }\end{array}$ & $\begin{array}{l}\text { d head liv } \\
\text { ols, and } \\
\text { level are } \\
\text { ayed in C } \\
\text { Column } \\
\text { Column } \\
\text { described }\end{array}$ & $\begin{array}{l}\text { vith a spo } \\
\mathrm{mn}(3) \text { on } \\
\mathrm{d} \text { in Colur } \\
\text { in (7). Th } \\
\text { Column ( } \\
\text { presents } \\
\text { ppendix }\end{array}$ & $\begin{array}{l}\text { and } 0 \text { oth } \\
\text { ntrols for } \\
\text { ), and at } \\
\text { S regres } \\
\text { ows sepa } \\
\text { natching } \\
\text { A.1. Abs }\end{array}$ & $\begin{array}{l}\text { se. The } h \\
\text { el charac } \\
\text { former ov } \\
\text { (instrume } \\
\text { ly the effe } \\
\text { nate usin } \\
\text { e value o }\end{array}$ & $\begin{array}{l}\text { hold is the } \\
\text { ics. Colur } \\
\text { level in C } \\
\text { the treat } \\
\text { early an } \\
\text { propensi } \\
\text { atistics in }\end{array}$ & $\begin{array}{l}\text { of obser } \\
\text { ) adds th } \\
\text { n (6). Th } \\
\text { t variable } \\
\text { treatme } \\
\text { ore of th } \\
\text { ntheses. }\end{array}$ & $\begin{array}{l}\text { 7. Colun } \\
\text { servatior } \\
\text { uced-for } \\
\text { erty Rig } \\
\text { The F-st } \\
\text { bability } \\
\text { nificant }\end{array}$ \\
\hline
\end{tabular}


Appendix Table A.8 - NUMBER OF OFFSPRING OF THE HOUSEHOLD HEAD $\geq 14$ YEARS OLD

\begin{tabular}{|c|c|c|c|c|c|c|c|c|c|c|}
\hline \multicolumn{11}{|c|}{ Appendix Table A.8 - NUMBER OF OFFSPRING OF THE HOUSEHOLD HEAD $\geq 14$ YEARS OLD } \\
\hline & $(1)$ & $(2)$ & $(3)$ & $(4)$ & $(5)$ & $(6)$ & $(7)$ & $(8)$ & (9) & $(10)$ \\
\hline Property Right & $\begin{array}{l}-0.01 \\
(0.06)\end{array}$ & $\begin{array}{l}-0.03 \\
(0.15)\end{array}$ & $\begin{array}{c}0.01 \\
(0.06)\end{array}$ & $\begin{array}{l}-0.06 \\
(0.37)\end{array}$ & $\begin{array}{l}-0.01 \\
(0.06)\end{array}$ & $\begin{array}{l}-0.01 \\
(0.06)\end{array}$ & & $\begin{array}{l}-0.18 \\
(0.84)\end{array}$ & & $\begin{array}{c}0.05 \\
(0.26)\end{array}$ \\
\hline Property Right Offer & & & & & & & $\begin{array}{l}-0.17 \\
(0.85)\end{array}$ & & & \\
\hline Property Right 1989 & & & & & & & & & $\begin{array}{l}-0.34 \\
(1.29)\end{array}$ & \\
\hline Property Right 1998 & & & & & & & & & $\begin{array}{l}0.16 \\
(0.77)\end{array}$ & \\
\hline Parcel Surface & $\begin{array}{c}0.00 \\
(1.00)\end{array}$ & & $\begin{array}{c}0.00 \\
(1.12)\end{array}$ & $\begin{array}{l}0.00^{*} \\
(1.92)\end{array}$ & $\begin{array}{c}0.00 \\
(0.96)\end{array}$ & $\begin{array}{c}0.00 \\
(1.55)\end{array}$ & $\begin{array}{c}0.00 \\
(0.82)\end{array}$ & $\begin{array}{l}0.00 \\
(0.91)\end{array}$ & $\begin{array}{l}0.00 \\
(1.05)\end{array}$ & \\
\hline Distance to Creek & $\begin{array}{l}0.10 \\
(0.95)\end{array}$ & & $\begin{array}{l}0.08 \\
(0.81)\end{array}$ & $\begin{array}{l}0.03 \\
(0.43)\end{array}$ & $\begin{array}{l}0.10 \\
(0.89)\end{array}$ & $\begin{array}{c}0.10 \\
(1.26)\end{array}$ & $\begin{array}{l}0.07 \\
(0.71)\end{array}$ & $\begin{array}{l}0.08 \\
(0.77)\end{array}$ & $\begin{array}{l}0.15 \\
(1.43)\end{array}$ & \\
\hline Block Corner & $\begin{array}{l}-0.06 \\
(0.23)\end{array}$ & & $\begin{array}{l}-0.01 \\
(0.02)\end{array}$ & $\begin{array}{c}0.14 \\
(0.58)\end{array}$ & $\begin{array}{l}-0.06 \\
(0.25)\end{array}$ & $\begin{array}{l}-0.06 \\
(0.40)\end{array}$ & $\begin{array}{l}-0.11 \\
(0.39)\end{array}$ & $\begin{array}{l}-0.08 \\
(0.30)\end{array}$ & $\begin{array}{l}-0.06 \\
(0.24)\end{array}$ & \\
\hline $\begin{array}{l}\text { Distance to Non-Squatted } \\
\text { Area }\end{array}$ & $\begin{array}{l}0.08 \\
(0.88)\end{array}$ & & $\begin{array}{l}0.06 \\
(0.71)\end{array}$ & $\begin{array}{l}0.04 \\
(0.53)\end{array}$ & $\begin{array}{l}0.08 \\
(0.89)\end{array}$ & $\begin{array}{c}0.08 \\
(1.33)\end{array}$ & $\begin{array}{l}0.08 \\
(0.89)\end{array}$ & $\begin{array}{l}0.08 \\
(0.87)\end{array}$ & $\begin{array}{c}0.08 \\
(0.88)\end{array}$ & \\
\hline Age of Original & 0.27 & & & 0.24 & 0.27 & 0.27 & 0.27 & 0.26 & 0.29 & \\
\hline Squatter $<50$ & $(1.47)$ & & & $(1.53)$ & (1.59) & $(1.61)$ & $(1.46)$ & $(1.41)$ & $(1.57)$ & \\
\hline Female Original Squatter & $\begin{array}{l}-0.02 \\
(0.10)\end{array}$ & & & $\begin{array}{l}-0.11 \\
(0.73)\end{array}$ & $\begin{array}{l}-0.02 \\
(0.10)\end{array}$ & $\begin{array}{l}-0.02 \\
(0.12)\end{array}$ & $\begin{array}{c}-0.02 \\
(0.11)\end{array}$ & $\begin{array}{l}-0.02 \\
(0.12)\end{array}$ & $\begin{array}{c}-0.02 \\
(0.09)\end{array}$ & \\
\hline Argentine Original & -0.16 & & & -0.10 & -0.16 & -0.16 & -0.19 & -0.20 & -0.12 & \\
\hline Squatter & $(0.34)$ & & & $(0.25)$ & $(0.38)$ & $(0.32)$ & $(0.42)$ & $(0.43)$ & $(0.26)$ & \\
\hline Years of Education of the & 0.00 & & & -0.01 & 0.00 & 0.00 & 0.00 & 0.00 & 0.00 & \\
\hline Original Squatter & $(0.04)$ & & & $(0.30)$ & $(0.03)$ & $(0.03)$ & $(0.06)$ & $(0.05)$ & $(0.09)$ & \\
\hline Argentine Father of the & 0.49 & & & 0.30 & $0.49^{*}$ & $0.49^{* *}$ & 0.52 & 0.51 & 0.47 & \\
\hline Original Squatter & $(1.33)$ & & & $(0.89)$ & $(1.71)$ & $(2.22)$ & $(1.41)$ & $(1.39)$ & $(1.27)$ & \\
\hline Years of Education of & 0.01 & & & 0.01 & 0.01 & 0.01 & 0.00 & 0.00 & 0.01 & \\
\hline Original Squatter's Father & $(0.14)$ & & & $(0.11)$ & $(0.12)$ & $(0.10)$ & $(0.06)$ & $(0.05)$ & $(0.11)$ & \\
\hline Argentine Mother of the & -0.12 & & & 0.07 & -0.12 & -0.12 & -0.11 & -0.10 & -0.08 & \\
\hline Original Squatter & $(0.31)$ & & & $(0.21)$ & $(0.34)$ & $(0.23)$ & $(0.28)$ & $(0.27)$ & $(0.22)$ & \\
\hline Years of Educ of Original & 0.04 & & & 0.02 & $0.04^{\prime}$ & 0.04 & 0.05 & $0.05^{\prime}$ & 0.05 & \\
\hline Squatter's Mother & $(0.47)$ & & & $(0.25)$ & $(0.48)$ & $(0.62)$ & $(0.54)$ & $(0.52)$ & $(0.53)$ & \\
\hline Constant & 0.48 & $1.69^{* * *}$ & $1.03^{* *}$ & 0.76 & 0.48 & 0.48 & 0.67 & 0.65 & 0.27 & \\
\hline & $(0.66)$ & $(12.83)$ & (2.11) & (1.31) & $(0.74)$ & $(0.69)$ & $(0.91)$ & $(0.89)$ & $(0.36)$ & \\
\hline F-stat & & & & & & & & & $3.16^{*}$ & \\
\hline Observations & 313 & 313 & 313 & 425 & 313 & 313 & 313 & 313 & 313 & 290 \\
\hline
\end{tabular}

Notes: The dependent variable is the number of sons or daughters of the household head older than 13 years old living in the house. The household is the unit of observation. Column (1) is summarized in Column 3 of Table 5. Column (2) includes no controls, and Column (3) only controls for parcel characteristics. Column (4) adds the observations for the San Martin neighborhood. Standard errors clustered at the block level are used in Column (5), and at the former owner level in Column (6). The reduced-form regression on the intention-to-treat variable Property Right Offer is displayed in Column (7). The 2SLS regression (instrumenting the treatment variable Property Right with the intention-to-treat variable Property Right Offer) is presented in Column (8). Column (9) shows separately the effect of early and late treatments. The F-stat tests the null hypothesis: Property Right $1989=$ Property Right 1998. Column (10) presents the matching estimate using the propensity score of the probability of attrition (with bootstrapped standard errors). The control variables are described in Appendix Table A.1. Absolute value of $t$ statistics in parentheses. ${ }^{*}$ Significant at $10 \%$; ${ }^{* *}$ significant at $5 \%$; *** significant at $1 \%$. 
Appendix Table A.9 - NUMBER OF OTHER RELATIVES (NO SPOUSE OR OFFSPRING OF THE HOUSEHOLD HEAD)

\begin{tabular}{|c|c|c|c|c|c|c|c|c|c|c|}
\hline & $(1)$ & $(2)$ & $(3)$ & $(4)$ & $(5)$ & $(6)$ & $(7)$ & $(8)$ & (9) & $(10)$ \\
\hline Property Right & $\begin{array}{c}-0.68^{\star \star \star} \\
(3.53)\end{array}$ & $\begin{array}{c}-0.53^{\star \star \star} \\
(2.75)\end{array}$ & $\begin{array}{c}-0.55^{\star * *} \\
(2.75)\end{array}$ & $\begin{array}{c}-0.56^{\star \star \star} \\
(3.23)\end{array}$ & $\begin{array}{c}-0.68^{\star * *} \\
(3.51)\end{array}$ & $\begin{array}{c}-0.68^{\star * \star} \\
(4.97)\end{array}$ & & $\begin{array}{c}-0.90^{* * *} \\
(3.97)\end{array}$ & & $\begin{array}{c}-0.70^{\star *} \\
(2.37)\end{array}$ \\
\hline Property Right Offer & & & & & & & $\begin{array}{c}-0.82^{* * *} \\
(4.00)\end{array}$ & & & \\
\hline Property Right 1989 & & & & & & & & & $\begin{array}{l}-0.36 \\
(1.36)\end{array}$ & \\
\hline Property Right 1998 & & & & & & & & & $\begin{array}{c}-0.85^{* * *} \\
(3.92)\end{array}$ & \\
\hline Parcel Surface & $\begin{array}{l}-0.00 \\
(0.08)\end{array}$ & & $\begin{array}{c}0.00 \\
(0.02)\end{array}$ & $\begin{array}{l}-0.00 \\
(0.04)\end{array}$ & $\begin{array}{l}-0.00 \\
(0.10)\end{array}$ & $\begin{array}{l}-0.00 \\
(0.21)\end{array}$ & $\begin{array}{l}-0.00 \\
(0.56)\end{array}$ & $\begin{array}{l}-0.00 \\
(0.19)\end{array}$ & $\begin{array}{l}-0.00 \\
(0.13)\end{array}$ & \\
\hline Distance to Creek & $\begin{array}{l}-0.08 \\
(0.76)\end{array}$ & & $\begin{array}{l}-0.09 \\
(0.85)\end{array}$ & $\begin{array}{l}-0.02 \\
(0.32)\end{array}$ & $\begin{array}{l}-0.08 \\
(0.73)\end{array}$ & $\begin{array}{l}-0.08 \\
(1.09)\end{array}$ & $\begin{array}{l}-0.12 \\
(1.18)\end{array}$ & $\begin{array}{l}-0.10 \\
(0.96)\end{array}$ & $\begin{array}{l}-0.13 \\
(1.22)\end{array}$ & \\
\hline Block Corner & $\begin{array}{c}0.03 \\
(0.10)\end{array}$ & & $\begin{array}{c}0.00 \\
(0.01)\end{array}$ & $\begin{array}{l}-0.06 \\
(0.26)\end{array}$ & $\begin{array}{c}0.03 \\
(0.12)\end{array}$ & $\begin{array}{c}0.03 \\
(0.16)\end{array}$ & $\begin{array}{l}-0.13 \\
(0.46)\end{array}$ & $\begin{array}{c}0.00 \\
(0.01)\end{array}$ & $\begin{array}{c}0.03 \\
(0.11)\end{array}$ & \\
\hline Distance to Non-Squatted & -0.12 & & -0.12 & -0.07 & -0.12 & $-0.12^{* *}$ & -0.11 & -0.12 & -0.12 & \\
\hline Area & $(1.23)$ & & $(1.18)$ & $(0.86)$ & $(1.32)$ & $(2.17)$ & $(1.18)$ & $(1.23)$ & $(1.22)$ & \\
\hline Age of Original & $-0.35^{\star}$ & & & $-0.43^{* * *}$ & $-0.35^{*}$ & $-0.35^{*}$ & $-0.32^{*}$ & $-0.36^{*}$ & $-0.36^{*}$ & \\
\hline Squatter $<50$ & $(1.80)$ & & & $(2.59)$ & $(1.94)$ & $(2.07)$ & $(1.68)$ & $(1.87)$ & $(1.89)$ & \\
\hline Female Original Squatter & $\begin{array}{l}0.32^{*} \\
(166)\end{array}$ & & & $\begin{array}{c}0.26 \\
(156)\end{array}$ & $\begin{array}{l}0.32^{*} \\
(1.77)\end{array}$ & $\begin{array}{c}0.32 \\
(156)\end{array}$ & $0.33^{*}$ & $\begin{array}{c}0.32 \\
(163)\end{array}$ & $\begin{array}{l}0.32^{*} \\
(165)\end{array}$ & \\
\hline Argentine Original & -0.71 & & & -0.53 & -0.71 & -0.71 & -0.73 & -0.76 & -0.75 & \\
\hline Squatter & $(1.49)$ & & & $(1.26)$ & $(1.48)$ & $(1.36)$ & $(1.54)$ & $(1.59)$ & $(1.57)$ & \\
\hline Years of Education of the & $-0.10^{*}$ & & & $-0.09^{* *}$ & $-0.10^{* *}$ & -0.10 & $-0.09^{*}$ & $-0.10^{*}$ & $-0.10^{*}$ & \\
\hline Original Squatter & $(1.78)$ & & & $(2.09)$ & $(2.08)$ & $(1.66)$ & $(1.72)$ & $(1.76)$ & $(1.84)$ & \\
\hline Argentine Father of the & $0.97^{* *}$ & & & $0.86^{\star \star}$ & $0.97^{*}$ & $0.97^{*}$ & $1.05^{\star * *}$ & $1.00^{* * *}$ & $1.00^{* * *}$ & \\
\hline Original Squatter & $(2.54)$ & & & $(2.43)$ & (1.91) & $(1.84)$ & $(2.74)$ & $(2.61)$ & $(2.61)$ & \\
\hline Years of Education of & -0.06 & & & -0.07 & -0.06 & -0.06 & -0.06 & -0.07 & -0.05 & \\
\hline Original Squatter's Father & $(0.65)$ & & & $(0.93)$ & $(0.51)$ & $(0.62)$ & $(0.74)$ & $(0.75)$ & $(0.63)$ & \\
\hline Argentine Mother of the & -0.37 & & & -0.31 & -0.37 & -0.37 & -0.37 & -0.35 & -0.40 & \\
\hline Original Squatter & $(0.96)$ & & & $(0.88)$ & $(0.84)$ & $(1.06)$ & $(0.98)$ & $(0.91)$ & $(1.05)$ & \\
\hline Years of Educ of Original & 0.03 & & & -0.02 & 0.03 & 0.03 & 0.04 & 0.03 & 0.02 & \\
\hline Squatter's Mother & $(0.30)$ & & & $(0.24)$ & $(0.29)$ & $(0.34)$ & $(0.45)$ & $(0.37)$ & $(0.25)$ & \\
\hline Constant & $\begin{array}{c}2.56^{* * *} \\
(3.42)\end{array}$ & $\begin{array}{c}1.25^{\star * *} \\
(8.66)\end{array}$ & $\begin{array}{c}1.63^{\star * *} \\
(3.05)\end{array}$ & $\begin{array}{c}2.55^{\star * *} \\
(4.21)\end{array}$ & $\begin{array}{c}2.56^{\star * *} \\
(3.73)\end{array}$ & $\begin{array}{c}2.56^{\star * *} \\
(5.05)\end{array}$ & $\begin{array}{c}2.87^{* * *} \\
(3.77)\end{array}$ & $\begin{array}{c}2.79^{* * *} \\
(3.66)\end{array}$ & $\begin{array}{c}2.77^{* * *} \\
(3.66)\end{array}$ & \\
\hline F-stat & & & & & & & & & $2.81^{*}$ & \\
\hline Observations & 313 & 313 & 313 & 425 & 313 & 313 & 313 & 313 & 313 & 290 \\
\hline
\end{tabular}

313

313

313

head. The household is the unit of observation. Column (1) is summarized in Column 4 of Table 5 . Column (2) includes no controls, and Column ( 3 ) only controls for parcel characteristics. Column (4) adds the observations for the San Martin neighborhood. Standard errors clustered at the block level are used in Column (5), and at the former owner level in Column (6). The reduced-form regression on the intention-to-treat variable Property Right Offer is displayed in Column (7). The 2SLS regression (instrumenting the treatment variable Property Right with the intention-to-treat variable Property Right Offer) is presented in Column (8). Column (9) shows separately the effect of early and late treatments. The F-stat tests the null hypothesis: Property Right $1989=$ Property Right 1998 . Column (10) presents the matching estimate using the propensity score of the probability of attrition (with bootstrapped standard errors). The control variables are described in Appendix Table A.1. Absolute value of $t$ statistics in parentheses. ${ }^{*}$ Significant at $10 \% ;{ }^{* *}$ significant at $5 \% ;{ }^{* * *}$ significant at $1 \%$. 


\begin{tabular}{|c|c|c|c|c|c|c|c|c|c|c|c|c|}
\hline \multicolumn{13}{|c|}{ Appendix Table A.10 - NUMBER OF OFFSPRING OF THE HOUSEHOLD HEAD 5-13 YEARS OLD } \\
\hline & $(1)$ & $(2)$ & (3) & $(4)$ & $(5)$ & (6) & $(7)$ & $(8)$ & (9) & $(10)$ & (11) & (12) \\
\hline Property Right & $\begin{array}{c}-0.17 \\
(1.18)\end{array}$ & $\begin{array}{c}-0.22 \\
(1.51)\end{array}$ & $\begin{array}{c}-0.23 \\
(1.56)\end{array}$ & $\begin{array}{l}-0.21^{*} \\
(1.66)\end{array}$ & $\begin{array}{c}-0.17 \\
(1.23)\end{array}$ & $\begin{array}{l}-0.17 \\
(0.99)\end{array}$ & & $\begin{array}{c}-0.12 \\
(0.72)\end{array}$ & & $\begin{array}{c}-0.12 \\
(0.75)\end{array}$ & & \\
\hline Property Right Offer & & & & & & & $\begin{array}{l}-0.11 \\
(0.72)\end{array}$ & & & & & \\
\hline Property Right 1989 & & & & & & & & & $\begin{array}{l}-0.38^{*} \\
(1.88)\end{array}$ & & $\begin{array}{l}-0.38^{*} \\
(1.77)\end{array}$ & \\
\hline Property Right 1998 & & & & & & & & & $\begin{array}{l}-0.06 \\
(0.37)\end{array}$ & & & $\begin{array}{l}-0.08 \\
(0.46)\end{array}$ \\
\hline Parcel Surface & $\begin{array}{c}0.00 \\
(0.14)\end{array}$ & & $\begin{array}{c}0.00 \\
(0.24)\end{array}$ & $\begin{array}{l}-0.00 \\
(0.21)\end{array}$ & $\begin{array}{c}0.00 \\
(0.14)\end{array}$ & $\begin{array}{c}0.00 \\
(0.14)\end{array}$ & $\begin{array}{c}0.00 \\
(0.10)\end{array}$ & $\begin{array}{c}0.00 \\
(0.17)\end{array}$ & $\begin{array}{c}0.00 \\
(0.18)\end{array}$ & & & \\
\hline Distance to Creek & $\begin{array}{c}0.01 \\
(0.10)\end{array}$ & & $\begin{array}{l}-0.04 \\
(0.49)\end{array}$ & $\begin{array}{c}0.04 \\
(0.86)\end{array}$ & $\begin{array}{c}0.01 \\
(0.11)\end{array}$ & $\begin{array}{c}0.01 \\
(0.16)\end{array}$ & $\begin{array}{c}0.01 \\
(0.12)\end{array}$ & $\begin{array}{c}0.01 \\
(0.16)\end{array}$ & $\begin{array}{c}0.04 \\
(0.53)\end{array}$ & & & \\
\hline Block Corner & $\begin{array}{l}-0.01 \\
(0.06)\end{array}$ & & $\begin{array}{l}-0.01 \\
(0.07)\end{array}$ & $\begin{array}{l}-0.07 \\
(0.39)\end{array}$ & $\begin{array}{l}-0.01 \\
(0.06)\end{array}$ & $\begin{array}{l}-0.01 \\
(0.06)\end{array}$ & $\begin{array}{l}-0.02 \\
(0.12)\end{array}$ & $\begin{array}{l}-0.01 \\
(0.03)\end{array}$ & $\begin{array}{l}-0.01 \\
(0.06)\end{array}$ & & & \\
\hline Distance to Non-Squatted & 0.03 & & 0.00 & 0.07 & 0.03 & 0.03 & 0.03 & 0.03 & 0.03 & & & \\
\hline Area & $(0.42)$ & & $(0.03)$ & $(1.07)$ & $(0.46)$ & $(0.37)$ & $(0.43)$ & $(0.42)$ & $(0.42)$ & & & \\
\hline Age of Original & $0.93^{* * *}$ & & & $0.76^{* * *}$ & $0.93^{* * *}$ & $0.93^{* * *}$ & $0.94^{* \star *}$ & $0.93^{\star * *}$ & $0.94^{* \star *}$ & & & \\
\hline Squatter $<50$ & $(6.48)$ & & & $(6.28)$ & $(5.95)$ & (13.02) & $(6.54)$ & $(6.50)$ & $(6.56)$ & & & \\
\hline Female Original Squatter & $\begin{array}{l}-0.15 \\
(1.03)\end{array}$ & & & $\begin{array}{l}-0.02 \\
(0.19)\end{array}$ & $\begin{array}{c}-0.15 \\
(1.01)\end{array}$ & $\begin{array}{l}-0.15 \\
(1.00)\end{array}$ & $\begin{array}{c}-0.15 \\
(1.01)\end{array}$ & $\begin{array}{c}-0.15 \\
(1.02)\end{array}$ & $\begin{array}{l}-0.15 \\
(1.02)\end{array}$ & & & \\
\hline Argentine Original & 0.26 & & & 0.21 & 0.26 & 0.26 & 0.27 & 0.27 & 0.28 & & & \\
\hline Squatter & $(0.72)$ & & & $(0.69)$ & $(0.71)$ & $(0.78)$ & $(0.76)$ & $(0.75)$ & $(0.79)$ & & & \\
\hline Years of Education of the & -0.01 & & & -0.01 & -0.01 & -0.01 & -0.01 & -0.01 & -0.01 & & & \\
\hline Original Squatter & $(0.35)$ & & & $(0.17)$ & $(0.36)$ & $(0.46)$ & $(0.35)$ & $(0.36)$ & $(0.31)$ & & & \\
\hline Argentine Father of the & -0.29 & & & -0.15 & -0.29 & -0.29 & -0.29 & -0.30 & -0.31 & & & \\
\hline Original Squatter & $(1.03)$ & & & $(0.57)$ & $(0.94)$ & $(1.00)$ & $(1.02)$ & $(1.05)$ & $(1.09)$ & & & \\
\hline Years of Education of & $-0.13^{\star *}$ & & & $-0.13^{* *}$ & $-0.13^{\star *}$ & $-0.13^{\star \star *}$ & $-0.13^{*}$ & $-0.13^{*}$ & $-0.13^{* *}$ & & & \\
\hline Original Squatter's Father & (1.99) & & & $(2.36)$ & $(2.18)$ & $(3.07)$ & (1.95) & (1.95) & $(2.02)$ & & & \\
\hline Argentine Mother of the & -0.22 & & & -0.29 & -0.22 & -0.22 & -0.23 & -0.23 & -0.20 & & & \\
\hline Original Squatter & $(0.78)$ & & & $(1.12)$ & $(0.61)$ & $(1.56)$ & $(0.81)$ & $(0.80)$ & $(0.70)$ & & & \\
\hline Years of Educ of Original & $\begin{array}{l}0.05 \\
(070)\end{array}$ & & & $\begin{array}{l}0.05 \\
(074)\end{array}$ & 0.05 & $\begin{array}{l}0.05 \\
(0.53)\end{array}$ & $\begin{array}{l}0.05 \\
(070)\end{array}$ & $\begin{array}{l}0.05 \\
(069)\end{array}$ & $\begin{array}{l}0.05 \\
075)\end{array}$ & & & \\
\hline Squatter's Mother & $(0.70)$ & & & $(0.74)$ & $(0.64)$ & $(0.53)$ & $(0.70)$ & $(0.69)$ & $(0.75)$ & & & \\
\hline & $\begin{array}{l}1.17^{\star *} \\
(2.09)\end{array}$ & $\begin{array}{c}1.06^{\star \star \star} \\
(9.82)\end{array}$ & $\begin{array}{c}1.07^{\star \star \star} \\
(2.66)\end{array}$ & $\begin{array}{l}1.12^{\star *} \\
(2.51)\end{array}$ & $\begin{array}{l}1.17^{\star *} \\
(2.12)\end{array}$ & $\begin{array}{l}1.17^{* \star \star} \\
(3.65)\end{array}$ & $\begin{array}{l}1.12^{\star *} \\
(1.97)\end{array}$ & $\begin{array}{l}1.12^{\star \star} \\
(1.97)\end{array}$ & $\begin{array}{c}1.03^{*} \\
(1.82)\end{array}$ & & & \\
\hline F-stat & & & & & & & & & 2.19 & & & \\
\hline Observations & 313 & 313 & 313 & 425 & 313 & 313 & 313 & 313 & 313 & 290 & 145 & 217 \\
\hline $\begin{array}{l}\text { Notes: The dependent vari } \\
\text { Column (1) is summarized } \\
\text { the San Martin neighborho } \\
\text { intention-to-treat variable } \\
\text { variable Property Right Off } \\
\text { treatments. The F-stat test } \\
\text { (12) present the matching } \\
\text { Table A.1. Absolute value }\end{array}$ & $\begin{array}{l}\text { le is the } \\
\text { Column }\end{array}$ & $\begin{array}{l}\text { ber of so } \\
\text { f Table } 5 . \\
\text { rors clust } \\
\text { Offer is }\end{array}$ & $\begin{array}{l}\text { or daught } \\
\text { lumn (2) }\end{array}$ & $=$ Prop & Right 1 & $\begin{array}{l}\text { ssion (in } \\
\text { imarized } \\
\text { For treat }\end{array}$ & $\begin{array}{l}\text { menting } \\
\text { Column } 6 \\
\text { tt, early t }\end{array}$ & $\begin{array}{l}\text { yner leve } \\
\text { treatmer } \\
\text { Table 5, } \\
\text { ment an }\end{array}$ & $\begin{array}{l}\text { riable } P \\
\text { ch show } \\
\text { e treatm }\end{array}$ & $\begin{array}{l}\text { usehol } \\
\text { umn (4 } \\
\text { he redu } \\
\text { ty Righ } \\
\text { arately } \\
\text { especti }\end{array}$ & $\begin{array}{l}\text { he unit } \\
\text { ls the ob } \\
\text { orm reg } \\
\text { the in } \\
\text { Column } \\
\text { Colum }\end{array}$ & $\begin{array}{l}\text { ervation } \\
\text { ations fo } \\
\text { on on th } \\
\text { n-to-trea } \\
\text { and lat } \\
\text { ) throug } \\
\text { Appendi }\end{array}$ \\
\hline
\end{tabular}




\begin{tabular}{|c|c|c|c|c|c|c|c|c|c|c|c|c|}
\hline \multicolumn{13}{|c|}{ Appendix Table A.11 - NUMBER OF OFFSPRING OF THE HOUSEHOLD HEAD 0-4 YEARS OLD } \\
\hline & $(1)$ & $(2)$ & $(3)$ & $(4)$ & $(5)$ & $(6)$ & $(7)$ & $(8)$ & $(9)$ & $(10)$ & (11) & (12) \\
\hline Property Right & $\begin{array}{c}-0.07 \\
(1.03)\end{array}$ & $\begin{array}{c}-0.07 \\
(1.05)\end{array}$ & $\begin{array}{c}-0.07 \\
(1.01)\end{array}$ & $\begin{array}{c}-0.07 \\
(1.09)\end{array}$ & $\begin{array}{l}-0.07 \\
(0.91)\end{array}$ & $\begin{array}{c}-0.07^{*} \\
(1.80)\end{array}$ & & $\begin{array}{l}-0.00 \\
(0.04)\end{array}$ & & $\begin{array}{c}-0.06 \\
(0.71)\end{array}$ & & \\
\hline Property Right Offer & & & & & & & $\begin{array}{l}-0.00 \\
(0.04)\end{array}$ & & & & & \\
\hline Property Right 1989 & & & & & & & & & $\begin{array}{l}-0.08 \\
(0.81)\end{array}$ & & $\begin{array}{l}-0.05 \\
(0.42)\end{array}$ & \\
\hline Property Right 1998 & & & & & & & & & $\begin{array}{l}-0.07 \\
(0.86)\end{array}$ & & & $\begin{array}{l}-0.04 \\
(0.49)\end{array}$ \\
\hline Parcel Surface & $\begin{array}{c}0.00 \\
(0.78)\end{array}$ & & $\begin{array}{c}0.00 \\
(0.93)\end{array}$ & $\begin{array}{c}0.00 \\
(0.23)\end{array}$ & $\begin{array}{c}0.00 \\
(0.67)\end{array}$ & $\begin{array}{c}0.00 \\
(0.85)\end{array}$ & $\begin{array}{c}0.00 \\
(0.86)\end{array}$ & $\begin{array}{c}0.00 \\
(0.87)\end{array}$ & $\begin{array}{c}0.00 \\
(0.79)\end{array}$ & & & \\
\hline Distance to Creek & $\begin{array}{l}-0.01 \\
(0.21)\end{array}$ & & $\begin{array}{c}0.00 \\
(0.04)\end{array}$ & $\begin{array}{c}0.02 \\
(0.68)\end{array}$ & $\begin{array}{l}-0.01 \\
(0.20)\end{array}$ & $\begin{array}{l}-0.01 \\
(0.31)\end{array}$ & $\begin{array}{c}-0.00 \\
(0.03)\end{array}$ & $\begin{array}{c}-0.00 \\
(0.03)\end{array}$ & $\begin{array}{l}-0.01 \\
(0.17)\end{array}$ & & & \\
\hline Block Corner & $\begin{array}{l}-0.03 \\
(0.32)\end{array}$ & & $\begin{array}{c}0.00 \\
(0.04)\end{array}$ & $\begin{array}{l}-0.00 \\
(0.05)\end{array}$ & $\begin{array}{l}-0.03 \\
(0.37)\end{array}$ & $\begin{array}{l}-0.03 \\
(0.31)\end{array}$ & $\begin{array}{l}-0.02 \\
(0.24)\end{array}$ & $\begin{array}{l}-0.02 \\
(0.24)\end{array}$ & $\begin{array}{l}-0.03 \\
(0.32)\end{array}$ & & & \\
\hline Distance to Non Squatted & 0.03 & & 0.03 & 0.03 & 0.03 & 0.03 & 0.03 & 0.03 & 0.03 & & & \\
\hline Area & $(0.74)$ & & $(0.96)$ & $(0.99)$ & $(0.75)$ & $(0.64)$ & $(0.74)$ & $(0.74)$ & $(0.73)$ & & & \\
\hline Age of Original & $0.15^{\star *}$ & & & $0.15^{* \star *}$ & $0.15^{\star *}$ & $0.15^{* \star *}$ & $0.16^{\star \star}$ & $0.16^{\star *}$ & $0.15^{\star \star}$ & & & \\
\hline Squatter $<50$ & $(2.23)$ & & & $(2.60)$ & $(2.12)$ & $(4.65)$ & (2.29) & $(2.28)$ & $(2.22)$ & & & \\
\hline Female Original Squatter & $\begin{array}{c}0.04 \\
(0.55)\end{array}$ & & & $\begin{array}{c}0.10^{*} \\
(1.70)\end{array}$ & $\begin{array}{c}0.04 \\
(0.58)\end{array}$ & $\begin{array}{c}0.04 \\
(0.80)\end{array}$ & $\begin{array}{c}0.04 \\
(0.57)\end{array}$ & $\begin{array}{c}0.04 \\
(0.57)\end{array}$ & $\begin{array}{c}0.04 \\
(0.55)\end{array}$ & & & \\
\hline Argentine Original & -0.28 & & & $-0.29^{*}$ & $-0.28^{\star}$ & $-0.28^{* \star *}$ & -0.26 & -0.26 & -0.28 & & & \\
\hline Squatter & $(1.65)$ & & & $(1.94)$ & $(1.85)$ & $(4.87)$ & (1.55) & (1.55) & $(1.64)$ & & & \\
\hline Years of Education of the & 0.01 & & & -0.02 & 0.01 & 0.01 & 0.01 & 0.01 & 0.01 & & & \\
\hline Original Squatter & $(0.51)$ & & & $(1.01)$ & $(0.59)$ & $(0.66)$ & $(0.50)$ & $(0.50)$ & $(0.51)$ & & & \\
\hline Argentine Father of the & 0.11 & & & 0.10 & 0.11 & 0.11 & 0.10 & 0.10 & 0.11 & & & \\
\hline Original Squatter & $(0.81)$ & & & $(0.81)$ & (1.09) & $(1.38)$ & $(0.74)$ & $(0.74)$ & $(0.80)$ & & & \\
\hline Years of Education of & -0.00 & & & -0.00 & -0.00 & -0.00 & 0.00 & 0.00 & -0.00 & & & \\
\hline Original Squatter's Father & $(0.05)$ & & & $(0.01)$ & $(0.05)$ & $(0.11)$ & $(0.04)$ & $(0.04)$ & $(0.05)$ & & & \\
\hline Argentine Mother of the & 0.02 & & & 0.03 & 0.02 & 0.02 & 0.02 & 0.02 & 0.02 & & & \\
\hline Original Squatter & $(0.16)$ & & & $(0.27)$ & $(0.20)$ & $(0.34)$ & $(0.11)$ & $(0.11)$ & $(0.16)$ & & & \\
\hline $\begin{array}{l}\text { Years of Educ of Original } \\
\text { Squatter's Mother }\end{array}$ & $\begin{array}{l}-0.03 \\
(0.89)\end{array}$ & & & $\begin{array}{l}-0.01 \\
(0.17)\end{array}$ & $\begin{array}{l}-0.03 \\
(0.91)\end{array}$ & $\begin{array}{l}-0.03 \\
(0.95)\end{array}$ & $\begin{array}{l}-0.03 \\
(0.94)\end{array}$ & $\begin{array}{l}-0.03 \\
(0.94)\end{array}$ & $\begin{array}{l}-0.03 \\
(0.88)\end{array}$ & & & \\
\hline Constant & $\begin{array}{c}0.32 \\
(1.20)\end{array}$ & $\begin{array}{c}0.33^{* * *} \\
(6.78)\end{array}$ & $\begin{array}{c}0.15 \\
(0.84)\end{array}$ & $\begin{array}{l}0.35^{*} \\
(1.65)\end{array}$ & $\begin{array}{c}0.32 \\
(1.09)\end{array}$ & $\begin{array}{c}0.32 \\
(1.63)\end{array}$ & $\begin{array}{c}0.25 \\
(0.91)\end{array}$ & $\begin{array}{c}0.25 \\
(0.92)\end{array}$ & $\begin{array}{c}0.31 \\
(1.16)\end{array}$ & & & \\
\hline F-stat & & & & & & & & & 0.01 & & & \\
\hline Observations & 313 & 313 & 313 & 425 & 313 & 313 & 313 & 313 & 313 & 290 & 145 & 217 \\
\hline $\begin{array}{l}\text { Notes: The dependent vari } \\
\text { Column (1) is summarized } \\
\text { the San Martin neighborho } \\
\text { intention-to-treat variable } \\
\text { variable Property Right Of } \\
\text { treatments. The F-stat test } \\
\text { (12) present the matching } \\
\text { Table A.1. Absolute value }\end{array}$ & $\begin{array}{l}\text { null } \\
\text { timate u } \\
\text { statistic }\end{array}$ & $\begin{array}{l}\text { esis: } \mathrm{Pr} \\
\text { the prop } \\
\text { arenthe }\end{array}$ & $\begin{array}{l}\text { ty Right } \\
\text { ty score } \\
{ }^{*} \text { Signific }\end{array}$ & $\begin{array}{l}\text { Imn }(7) \text {. } \\
\text { (9) is the } \\
9=\text { Prop } \\
\text { he proba } \\
\text { at } 10 \% \text {; }\end{array}$ & $\begin{array}{l}2 \text { 2SLS } \\
\text { gression } \\
\text { Right } 19 \\
\text { y of attrit } \\
\text { gnificant }\end{array}$ & $\begin{array}{l}\text { n (5), and } \\
\text { ession (ins } \\
\text { nmarized } \\
\text { For treat } \\
\text { (with boo } \\
\% ;{ }^{* *} \text { sig }\end{array}$ & $\begin{array}{l}\text { nenting } \\
\text { olumn } 8 \\
\text { t, early } \\
\text { ipped st } \\
\text { ant at } 1\end{array}$ & $\begin{array}{l}\text { ner level } \\
\text { treatmen } \\
\text { Table 5, } \\
\text { ment and } \\
\text { ard errors }\end{array}$ & $\begin{array}{l}\text { riable } \mathrm{Pr} \\
\text { ch shows } \\
\text { e treatme } \\
\text { he contr }\end{array}$ & $\begin{array}{l}\text { ousehol } \\
\text { lumn (4 } \\
\text { he redu } \\
\text { rty Righ } \\
\text { parately } \\
\text { respecti } \\
\text { ariables }\end{array}$ & $\begin{array}{l}\text { ne unit } \\
\mathrm{s} \text { the ob } \\
\text { orm reg } \\
\text { the int } \\
\text { ffect of } \\
\text { Column } \\
\text { lescribe }\end{array}$ & $\begin{array}{l}\text { ervation } \\
\text { ations fo } \\
\text { on on th } \\
\text { n-to-trec } \\
\text { and lat } \\
\text { throug } \\
\text { Appendi }\end{array}$ \\
\hline
\end{tabular}




\begin{tabular}{|c|c|c|c|c|c|c|c|c|c|c|c|c|}
\hline \multicolumn{13}{|c|}{ Appendix Table A.12 - SCHOOL ACHIEVEMENT (OFFSPRING OF THE HOUSEHOLD HEAD 6-20 YEARS OLD) } \\
\hline & $(1)$ & $(2)$ & (3) & $(4)$ & (5) & $(6)$ & $(7)$ & (8) & (9) & $(10)$ & $(11)$ & $(12)$ \\
\hline Property Right & $\begin{array}{c}0.22 \\
(1.15)\end{array}$ & $\begin{array}{c}0.18 \\
(0.98)\end{array}$ & $\begin{array}{c}0.25 \\
(1.31)\end{array}$ & $\begin{array}{c}0.22 \\
(1.04)\end{array}$ & $\begin{array}{c}0.22 \\
(1.15)\end{array}$ & $\begin{array}{c}0.22 \\
(0.82)\end{array}$ & & $\begin{array}{l}0.44^{*} \\
(1.8)\end{array}$ & & $\begin{array}{c}0.08 \\
(0.33)\end{array}$ & & \\
\hline Property Right Offer & & & & & & & $\begin{array}{l}0.40^{*} \\
(1.81)\end{array}$ & & & & & \\
\hline Property Right 1989 & & & & & & & & & $\begin{array}{l}0.69^{\star *} \\
(2.29)\end{array}$ & & $\begin{array}{c}1.19^{* * *} \\
(2.77)\end{array}$ & \\
\hline Property Right 1998 & & & & & & & & & $\begin{array}{c}0.03 \\
(0.13)\end{array}$ & & & $\begin{array}{l}-0.17 \\
(0.54)\end{array}$ \\
\hline Parcel Surface & $\begin{array}{c}0.00 \\
(0.69)\end{array}$ & & $\begin{array}{l}0.00 \\
(0.34)\end{array}$ & $\begin{array}{l}0.00 \\
(0.62)\end{array}$ & $\begin{array}{l}0.00 \\
(0.62)\end{array}$ & $\begin{array}{c}0.00 \\
(0.73)\end{array}$ & $\begin{array}{l}0.00 \\
(0.25)\end{array}$ & $\begin{array}{c}0.00 \\
(0.56)\end{array}$ & $\begin{array}{c}0.00 \\
(0.79)\end{array}$ & & & \\
\hline Distance to Creek & $\begin{array}{c}0.12 \\
(1.11)\end{array}$ & & $\begin{array}{l}0.13 \\
(1.18)\end{array}$ & $\begin{array}{c}0.12 \\
(0.98)\end{array}$ & $\begin{array}{c}0.12 \\
(1.06)\end{array}$ & $\begin{array}{c}0.12 \\
(1.14)\end{array}$ & $\begin{array}{c}0.17 \\
(1.48)\end{array}$ & $\begin{array}{c}0.14 \\
(131)\end{array}$ & $\begin{array}{c}0.07 \\
(0.59)\end{array}$ & & & \\
\hline Block Corner & $\begin{array}{l}-0.52^{*} \\
(1.82)\end{array}$ & & $\begin{array}{l}-0.29 \\
(1.09)\end{array}$ & $\begin{array}{l}-0.52 \\
(1.49)\end{array}$ & $\begin{array}{c}-0.52 \\
(1.55)\end{array}$ & $\begin{array}{l}-0.52^{*} \\
(1.83)\end{array}$ & $\begin{array}{l}-0.38 \\
(1.26)\end{array}$ & $\begin{array}{l}-0.47 \\
(1.63)\end{array}$ & $\begin{array}{l}-0.49^{*} \\
(1.70)\end{array}$ & & & \\
\hline $\begin{array}{l}\text { Distance to Non-Squatted } \\
\text { Area }\end{array}$ & $\begin{array}{l}-0.12 \\
(1.08)\end{array}$ & -0.25 & $\begin{array}{l}-0.08 \\
(0.71)\end{array}$ & $\begin{array}{l}-0.12 \\
(0.97)\end{array}$ & $\begin{array}{l}-0.12 \\
(0.92)\end{array}$ & $\begin{array}{c}-0.12 \\
(1.1)\end{array}$ & $\begin{array}{c}-0.13 \\
(1.21)\end{array}$ & $\begin{array}{l}-0.14 \\
(1.24)\end{array}$ & $\begin{array}{c}-0.10 \\
(0.95)\end{array}$ & & & \\
\hline Male & $\begin{array}{l}-0.24 \\
(1.35)\end{array}$ & $\begin{array}{l}(1.37) \\
-0.34^{* * *}\end{array}$ & $\begin{array}{l}-0.23 \\
(1.26)\end{array}$ & $\begin{array}{l}-0.24 \\
(1.39)\end{array}$ & $\begin{array}{l}-0.24 \\
(1.39)\end{array}$ & $\begin{array}{l}-0.24 \\
(1.59)\end{array}$ & $\begin{array}{l}-0.22 \\
(1.24)\end{array}$ & $\begin{array}{l}-0.25 \\
(1.36)\end{array}$ & $\begin{array}{l}-0.24 \\
(1.31)\end{array}$ & & & \\
\hline Child Age & $\begin{array}{l}-0.35^{* * *} \\
(16.31)\end{array}$ & $(15.72)$ & $\begin{array}{l}-0.34^{* * *} \\
(15.77)\end{array}$ & $\begin{array}{l}-0.35^{\star * *} \\
(14.1)\end{array}$ & $\begin{array}{l}-0.35^{* \star *} \\
(12.57)\end{array}$ & $\begin{array}{c}-0.35^{* * *} \\
(9.89)\end{array}$ & $\begin{array}{r}-0.34^{* * *} \\
(16.34)\end{array}$ & $\begin{array}{l}-0.35^{* * *} \\
(16.31)\end{array}$ & $\begin{array}{r}-0.34^{* * *} \\
(16.21)\end{array}$ & & & \\
\hline $\begin{array}{l}\text { Age of Original } \\
\text { Squatter }<50\end{array}$ & $\begin{array}{l}-0.14 \\
(0.66)\end{array}$ & & & $\begin{array}{l}-0.14 \\
(0.57)\end{array}$ & $\begin{array}{l}-0.14 \\
(0.62)\end{array}$ & $\begin{array}{l}-0.14 \\
(0.71)\end{array}$ & $\begin{array}{l}-0.13 \\
(0.64)\end{array}$ & $\begin{array}{l}-0.12 \\
(0.59)\end{array}$ & $\begin{array}{l}-0.16 \\
(0.78)\end{array}$ & & & \\
\hline Female Original Squatter & $\begin{array}{l}-0.47^{* *} \\
(251)\end{array}$ & & & $\begin{array}{l}-0.47^{* *} \\
(223)\end{array}$ & $\begin{array}{l}-0.47^{* *} \\
(235)\end{array}$ & $\begin{array}{l}-0.47^{* *} \\
(291)\end{array}$ & $\begin{array}{l}-0.46^{* *} \\
(247)\end{array}$ & $\begin{array}{l}-0.45^{\star *} \\
(238)\end{array}$ & $\begin{array}{c}-0.50^{* \star *} \\
(266)\end{array}$ & & & \\
\hline Argentine Original & 0.66 & & & $\begin{array}{l}0.66 \\
(119)\end{array}$ & 0.66 & $0.66^{* *}$ & $\begin{array}{l}0.75 \\
(135)\end{array}$ & $\begin{array}{l}0.73 \\
(131)\end{array}$ & $\begin{array}{l}0.54 \\
(0.97)\end{array}$ & & & \\
\hline Years of Education of the & $0.17^{* * *}$ & & & $0.17^{* *}$ & $0.17^{* *}$ & $0.17^{* * *}$ & $0.16^{* * *}$ & $0.16^{* * *}$ & $0.17^{* * *}$ & & & \\
\hline Original Squatter & $(2.96)$ & & & $(2.55)$ & $(2.39)$ & $(3.00)$ & $(2.89)$ & $(2.82)$ & $(2.93)$ & & & \\
\hline Argentine Father of the & $-1.29^{* \star *}$ & & & $-1.29^{* \star *}$ & $-1.29^{* * *}$ & $-1.29^{* \star *}$ & $-1.41^{* * *}$ & $-1.37^{* * *}$ & $-1.20^{* * *}$ & & & \\
\hline Original Squatter & $(3.15)$ & & & $(3.51)$ & $(3.63)$ & $(4.92)$ & $(3.38)$ & $(3.31)$ & $(2.93)$ & & & \\
\hline Years of Education of & 0.06 & & & 0.06 & 0.06 & 0.06 & 0.07 & 0.07 & 0.07 & & & \\
\hline Original Squatter's Father & $(0.72)$ & & & $(0.74)$ & $(0.71)$ & $(0.70)$ & $(0.75)$ & $(0.74)$ & $(0.76)$ & & & \\
\hline Argentine Mother of the & 0.16 & & & 0.16 & 0.16 & 0.16 & 0.15 & 0.19 & 0.08 & & & \\
\hline Original Squatter & $(0.46)$ & & & $(0.41)$ & $(0.47)$ & $(0.44)$ & $(0.43)$ & $(0.54)$ & $(0.23)$ & & & \\
\hline Years of Education of & 0.01 & & & 0.01 & 0.01 & 0.01 & 0.00 & 0.01 & -0.01 & & & \\
\hline Original Squatter's Mother & $(0.08)$ & & & $(0.07)$ & $(0.07)$ & $(0.07)$ & $(0.01)$ & $(0.14)$ & $(0.08)$ & & & \\
\hline Constant & $\begin{array}{c}2.64^{* * *} \\
(3.13)\end{array}$ & $\begin{array}{c}2.96^{\star * *} \\
(8.93)\end{array}$ & $\begin{array}{c}3.02^{* * *} \\
(5.1)\end{array}$ & $\begin{array}{l}2.64^{* * *} \\
(3.01)\end{array}$ & $\begin{array}{c}2.64^{* \star *} \\
(3.24)\end{array}$ & $\begin{array}{c}2.64^{* \star *} \\
(3.98)\end{array}$ & $\begin{array}{l}2.35^{\star \star *} \\
(2.72)\end{array}$ & $\begin{array}{r}2.45^{\star \star *} \\
(286)\end{array}$ & $\begin{array}{l}2.91^{* * *} \\
(3.42)\end{array}$ & & & \\
\hline F-stat & & & & & & & & & $4.09^{\star \star}$ & & & \\
\hline Observations & 436 & 436 & 436 & 436 & 436 & 436 & 436 & 436 & 436 & 382 & 165 & 292 \\
\hline $\begin{array}{l}\text { Notes: The dependent var } \\
\text { grade corresponding to the } \\
\text { Column (3) controls for ch } \\
\text { (4), and at the former ow } \\
\text { regression (instrumenting } \\
\text { summarized in Column } 2 \\
1998 \text {. For treatment, early } \\
\text { attrition (with bootstrapped } \\
\text { significant at 5\%; *** signifi }\end{array}$ & $\begin{array}{l}\text { ild age. } \\
\text { age, child } \\
\text { level in } \\
\text { treatmen } \\
\text { Table } 6, \mathrm{w} \\
\text { atment an } \\
\text { tandard er }\end{array}$ & $\begin{array}{l}\text { lumn (6). } \\
\text { ariable Prc } \\
\text { ch shows } \\
\text { late treatm } \\
\text { rs). The c }\end{array}$ & $\begin{array}{l}\text { oarately th } \\
\text { th, respect } \\
\text { trol variab }\end{array}$ & effect of $\mathrm{e}$, Colum & $\begin{array}{l}\text { y and late } \\
\text { (10) thro } \\
\text { ed in Ano }\end{array}$ & eatments. & $\begin{array}{l}\text { Column } 1 \\
\text { he house } \\
\text { at variab } \\
\text { rty Right } \\
\text { e F-stat } \\
t \text { the mat } \\
1\end{array}$ & $\begin{array}{l}\text { Table } 6 \\
\text { d level a } \\
\text { Property } \\
\text { er) is pre } \\
\text { s the nu }\end{array}$ & $\begin{array}{l}\text { umn (2) } \\
\text { sed in } \\
\text { t Offer }\end{array}$ & $\begin{array}{l}\text { f not } \\
\text { contro } \\
\text { (4), } \\
\text { playec } \\
\text { (8). C } \\
\text { erty F } \\
\text { pensit } \\
\text { anthes }\end{array}$ & $\begin{array}{l}\text { ling scho } \\
\text { child age } \\
\text { block le } \\
\text {,olumn ( } \\
\text { in (9) is t } \\
1989=\mathrm{F} \\
\text { re of the } \\
\text { Significa }\end{array}$ & $\begin{array}{l}\text { ninus th } \\
\text { d gender } \\
\text { 7 Colum } \\
\text { he 2SL } \\
\text { egressio } \\
\text { erty Righ } \\
\text { bability o } \\
\text { t } 10 \% \text {; * }\end{array}$ \\
\hline
\end{tabular}




\begin{tabular}{|c|c|c|c|c|c|c|c|c|c|c|c|c|}
\hline \multicolumn{13}{|c|}{ Appendix Table A.13 - PRIMARY SCHOOL COMPLETION (OFFSPRING OF THE HOUSEHOLD HEAD 13-20 YEARS OLD) } \\
\hline & (1) & $(2)$ & (3) & $(4)$ & $(5)$ & (6) & (7) & $(8)$ & $(9)$ & $(10)$ & $(11)$ & $(12)$ \\
\hline Property Right & $\begin{array}{c}0.02 \\
(0.45)\end{array}$ & $\begin{array}{c}0.01 \\
(0.34)\end{array}$ & $\begin{array}{c}0.03 \\
(0.64)\end{array}$ & $\begin{array}{c}0.02 \\
(0.44)\end{array}$ & $\begin{array}{c}0.02 \\
(0.42)\end{array}$ & $\begin{array}{c}0.02 \\
(0.63)\end{array}$ & & $\begin{array}{c}0.06 \\
(1.12)\end{array}$ & & $\begin{array}{l}-0.01 \\
(0.15)\end{array}$ & & \\
\hline Property Right Offer & & & & & & & $\begin{array}{c}0.06 \\
(1.13)\end{array}$ & & & & & \\
\hline Property Right 1989 & & & & & & & & & $\begin{array}{c}0.01 \\
(0.12)\end{array}$ & & $\begin{array}{c}0.00 \\
(0.03)\end{array}$ & \\
\hline Property Right 1998 & & & & & & & & & $\begin{array}{l}0.02 \\
(0.49)\end{array}$ & & & $\begin{array}{c}0.04 \\
(0.61)\end{array}$ \\
\hline Parcel Surface & $\begin{array}{l}0.00 \\
(0.40)\end{array}$ & & $\begin{array}{c}0.00 \\
(0.41)\end{array}$ & $\begin{array}{l}0.00 \\
(0.4)\end{array}$ & $\begin{array}{c}0.00 \\
(0.40)\end{array}$ & $\begin{array}{l}0.00 \\
(0.44)\end{array}$ & $\begin{array}{c}0.00 \\
(0.64)\end{array}$ & $\begin{array}{c}0.00 \\
(0.51)\end{array}$ & $\begin{array}{l}0.00 \\
(0.41)\end{array}$ & & & \\
\hline Distance to Creek & $\begin{array}{c}0.01 \\
(0.36)\end{array}$ & & $\begin{array}{l}-0.01 \\
(0.26)\end{array}$ & $\begin{array}{c}0.01 \\
(0.32)\end{array}$ & $\begin{array}{c}0.01 \\
(0.36)\end{array}$ & $\begin{array}{c}0.01 \\
(0.39)\end{array}$ & $\begin{array}{c}0.02 \\
(0.60)\end{array}$ & $\begin{array}{c}0.01 \\
(0.52)\end{array}$ & $\begin{array}{l}0.01 \\
(0.4)\end{array}$ & & & \\
\hline Block Corner & $\begin{array}{l}-0.05 \\
(0.74)\end{array}$ & & $\begin{array}{c}0.01 \\
(0.11)\end{array}$ & $\begin{array}{l}-0.05 \\
(0.74)\end{array}$ & $\begin{array}{l}-0.05 \\
(0.80)\end{array}$ & $\begin{array}{l}-0.05 \\
(1.44)\end{array}$ & $\begin{array}{l}-0.03 \\
(0.44)\end{array}$ & $\begin{array}{l}-0.04 \\
(0.63)\end{array}$ & $\begin{array}{l}-0.05 \\
(0.74)\end{array}$ & & & \\
\hline $\begin{array}{l}\text { Distance to Non-Squatted } \\
\text { Area }\end{array}$ & $\begin{array}{l}-0.03 \\
(1.17)\end{array}$ & & $\begin{array}{l}-0.03 \\
(1.26)\end{array}$ & $\begin{array}{l}-0.03 \\
(1.19)\end{array}$ & $\begin{array}{l}-0.03 \\
(1.46)\end{array}$ & $\begin{array}{l}-0.03^{*} \\
(1.89)\end{array}$ & $\begin{array}{l}-0.03 \\
(1.31)\end{array}$ & $\begin{array}{l}-0.03 \\
(1.32)\end{array}$ & $\begin{array}{l}-0.03 \\
(1.17)\end{array}$ & & & \\
\hline (3) & $\begin{array}{l}-0.02 \\
(0.52)\end{array}$ & $\begin{array}{l}-0.01 \\
(0.18)\end{array}$ & $\begin{array}{l}-0.01 \\
(0.26)\end{array}$ & $\begin{array}{l}-0.02 \\
(0.59)\end{array}$ & $\begin{array}{l}-0.02 \\
(0.65)\end{array}$ & $\begin{array}{l}-0.02 \\
(0.58)\end{array}$ & $\begin{array}{c}-0.02 \\
(0.44)\end{array}$ & $\begin{array}{c}-0.02 \\
(0.51)\end{array}$ & $\begin{array}{c}-0.02 \\
(0.54)\end{array}$ & & & \\
\hline Child Age & $\begin{array}{l}0.05^{\star * *} \\
(5.50)\end{array}$ & $\begin{array}{l}0.05^{* * *} \\
(5.26)\end{array}$ & $\begin{array}{l}0.05^{\star * *} \\
(5.27)\end{array}$ & $\begin{array}{l}0.05^{* * *} \\
(4.72)\end{array}$ & $\begin{array}{l}0.05^{\star * *} \\
(4.45)\end{array}$ & $\begin{array}{l}0.05^{\star * *} \\
(6.19)\end{array}$ & $\begin{array}{l}0.05^{\star * \star} \\
(5.55)\end{array}$ & $\begin{array}{l}0.05^{* * *} \\
(5.49)\end{array}$ & $\begin{array}{l}0.05^{\star \star *} \\
(5.5)\end{array}$ & & & \\
\hline $\begin{array}{l}\text { Age of Original } \\
\text { Squatter }<50\end{array}$ & $\begin{array}{c}0.05 \\
(1.07)\end{array}$ & & & $\begin{array}{c}0.05 \\
(1.00)\end{array}$ & $\begin{array}{c}0.05 \\
(0.99)\end{array}$ & $\begin{array}{c}0.05 \\
(1.16)\end{array}$ & $\begin{array}{c}0.05 \\
(1.10)\end{array}$ & $\begin{array}{c}0.06 \\
(1.12)\end{array}$ & $\begin{array}{c}0.05 \\
(1.07)\end{array}$ & & & \\
\hline Female Original Squatter & $-0.11^{* *}$ & & & $-0.11^{* *}$ & $-0.11^{* *}$ & $-0.11^{* *}$ & $-0.10^{* *}$ & $-0.10^{* *}$ & $-0.10^{* *}$ & & & \\
\hline 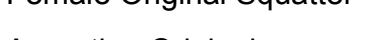 & (2.31) & & & $(2.03)$ & $(2.09)$ & $(2.3)$ & $(2.28)$ & $(2.19)$ & $(2.29)$ & & & \\
\hline $\begin{array}{l}\text { Argentine Original } \\
\text { Squatter }\end{array}$ & $\begin{array}{l}-0.05 \\
(0.36)\end{array}$ & & & $\begin{array}{l}-0.05 \\
(0.48)\end{array}$ & $\begin{array}{l}-0.05 \\
(0.59)\end{array}$ & $\begin{array}{l}-0.05 \\
(0.81)\end{array}$ & $\begin{array}{l}-0.03 \\
(0.25)\end{array}$ & $\begin{array}{l}-0.04 \\
(0.26)\end{array}$ & $\begin{array}{l}-0.05 \\
(0.34)\end{array}$ & & & \\
\hline $\begin{array}{l}\text { Yquatter } \\
\text { Years of Education of the }\end{array}$ & $0.03^{* *}$ & & & $0.03^{* *}$ & $0.03^{* *}$ & $0.03^{*}$ & $0.03^{* *}$ & $0.03^{\star \star}$ & $\begin{array}{l}(0.34) \\
0.03^{* *}\end{array}$ & & & \\
\hline Original Squatter & $(2.46)$ & & & $(2.47)$ & $(2.52)$ & (2.01) & (2.43) & $(2.42)$ & $(2.45)$ & & & \\
\hline Argentine Father of the & -0.08 & & & -0.08 & -0.08 & -0.08 & -0.10 & -0.10 & -0.09 & & & \\
\hline Original Squatter & $(0.87)$ & & & $(1.13)$ & $(1.17)$ & $(1.51)$ & $(1.06)$ & $(1.01)$ & $(0.88)$ & & & \\
\hline Years of Education of & $0.05^{\star *}$ & & & $0.05^{\star \star \star}$ & $0.05^{\star \star *}$ & $0.05^{* \star *}$ & $0.05^{* \star}$ & $0.05^{* *}$ & $0.05^{* \star}$ & & & \\
\hline Original Squatter's Father & $(2.35)$ & & & $(3.07)$ & $(3.64)$ & $(4.79)$ & $(2.37)$ & $(2.37)$ & $(2.34)$ & & & \\
\hline Argentine Mother of the & -0.07 & & & -0.07 & -0.07 & -0.07 & -0.07 & -0.06 & -0.07 & & & \\
\hline Original Squatter & $(0.85)$ & & & $(0.82)$ & $(0.87)$ & $(0.96)$ & $(0.85)$ & $(0.80)$ & $(0.83)$ & & & \\
\hline $\begin{array}{l}\text { Years of Education of } \\
\text { Original Squatter's }\end{array}$ & $\begin{array}{l}-0.02 \\
(0.99)\end{array}$ & & & $\begin{array}{l}-0.02 \\
(1.07)\end{array}$ & $\begin{array}{l}-0.02 \\
(1.10)\end{array}$ & $\begin{array}{l}-0.02 \\
(1.37)\end{array}$ & $\begin{array}{l}-0.02 \\
(1.03)\end{array}$ & $\begin{array}{l}-0.02 \\
(0.96)\end{array}$ & $\begin{array}{l}-0.02 \\
(0.97)\end{array}$ & & & \\
\hline Constant & $\begin{array}{l}-0.18 \\
(0.75)\end{array}$ & $\begin{array}{c}-0.03 \\
(0.21)\end{array}$ & $\begin{array}{l}-0.01 \\
(0.04)\end{array}$ & $\begin{array}{l}-0.18 \\
(0.68)\end{array}$ & $\begin{array}{l}-0.18 \\
(0.71)\end{array}$ & $\begin{array}{l}-0.18 \\
(0.85)\end{array}$ & $\begin{array}{l}-0.23 \\
(0.95)\end{array}$ & $\begin{array}{l}-0.22 \\
(0.91)\end{array}$ & $\begin{array}{l}-0.19 \\
(0.77)\end{array}$ & & & \\
\hline F-stat & & & & & & & & & 0.04 & & & \\
\hline Observations & 290 & 290 & 290 & 290 & 290 & 290 & 2.90 & 290 & 290 & 250 & 100 & 195 \\
\hline $\begin{array}{l}\text { Notes: The dependent vari } \\
\text { in Column } 3 \text { of Table } 6 \text {. Co } \\
\text { the household level are us } \\
\text { variable Property Right Off } \\
\text { Right Offer) is presented in } \\
\text { stat tests the null hypothes } \\
\text { matching estimates using } \\
\text { Absolute value of t statistic }\end{array}$ & $\begin{array}{l}\text { ble is a d } \\
\text { Imn (2) o } \\
d \text { in Colur }\end{array}$ & Column $(C$ & $\begin{array}{l}\text { probak } \\
\text { t t at } 10\end{array}$ & on summ & $\begin{array}{l}\text { red in Col } \\
\text { reatment } \\
\text { with boot } \\
\text { at } 5 \% \text {; *** }\end{array}$ & $\mathrm{n} 4$ of Tal & 6 , which & $\begin{array}{l}\text { e (6). Th } \\
\text { e Propert } \\
\text { ws separ } \\
\text { atment, } \\
\text { The contr }\end{array}$ & $\begin{array}{l}\text { inged-fo } \\
\text { ight with } \\
\text { ly the effe } \\
\text { ectively, } \\
\text { ariables }\end{array}$ & $\begin{array}{l}\text { f early } \\
\text { describs }\end{array}$ & $\begin{array}{l}\text { the int } \\
\text { eat var } \\
\text { te treat } \\
\text { ough }(1 \\
\text { Appen }\end{array}$ & $\begin{array}{l}\text { mmarize } \\
\text { ustered } \\
\text { n-to-trea } \\
\text { Propert } \\
\text { ts. The F } \\
\text { esent th } \\
\text { able A. } 1\end{array}$ \\
\hline
\end{tabular}




\begin{tabular}{|c|c|c|c|c|c|c|c|c|c|c|c|c|}
\hline \multicolumn{13}{|c|}{ Appendix Table A.14 - SECONDARY SCHOOL COMPLETION (OFFSPRING OF THE HOUSEHOLD HEAD 18-2 } \\
\hline & $(1)$ & $(2)$ & (3) & $(4)$ & (5) & (6) & $(7)$ & $(8)$ & (9) & $(10)$ & (11) & (12) \\
\hline Property Right & $\begin{array}{c}0.06 \\
(0.72)\end{array}$ & $\begin{array}{c}0.10 \\
(1.22)\end{array}$ & $\begin{array}{c}0.09 \\
(1.09)\end{array}$ & $\begin{array}{c}0.06 \\
(0.68)\end{array}$ & $\begin{array}{c}0.06 \\
(0.60)\end{array}$ & $\begin{array}{c}0.06 \\
(0.53)\end{array}$ & & $\begin{array}{c}0.10 \\
(0.87)\end{array}$ & & $\begin{array}{l}0.18^{* *} \\
(2.19)\end{array}$ & & \\
\hline Property Right Offer & & & & & & & $\begin{array}{l}0.09 \\
(0.87)\end{array}$ & & & & & \\
\hline Property Right 1989 & & & & & & & & & $\begin{array}{l}0.27^{*} \\
(1.93)\end{array}$ & & $\begin{array}{c}0.59^{* * *} \\
(3.16)\end{array}$ & \\
\hline Property Right 1998 & & & & & & & & & $\begin{array}{l}-0.01 \\
(0.12)\end{array}$ & & & $\begin{array}{c}0.06 \\
(0.63)\end{array}$ \\
\hline Parcel Surface & $\begin{array}{c}0.00 \\
(0.30)\end{array}$ & & $\begin{array}{c}0.00 \\
(0.45)\end{array}$ & $\begin{array}{c}0.00 \\
(0.30)\end{array}$ & $\begin{array}{c}0.00 \\
(0.30)\end{array}$ & $\begin{array}{l}0.00 \\
(0.5)\end{array}$ & $\begin{array}{l}0.00 \\
(0.44)\end{array}$ & $\begin{array}{l}0.00 \\
(0.39)\end{array}$ & $\begin{array}{l}0.00 \\
(0.08)\end{array}$ & & & \\
\hline Distance to Creek & $\begin{array}{l}0.05 \\
(1.04)\end{array}$ & & $\begin{array}{c}0.07 \\
(1.60)\end{array}$ & $\begin{array}{c}0.05 \\
(0.95)\end{array}$ & $\begin{array}{c}0.05 \\
(0.83)\end{array}$ & $\begin{array}{c}0.05 \\
(0.62)\end{array}$ & $\begin{array}{c}0.06 \\
(1.15)\end{array}$ & $\begin{array}{c}0.05 \\
(1.10)\end{array}$ & $\begin{array}{c}0.02 \\
(0.49)\end{array}$ & & & \\
\hline Block Corner & $\begin{array}{l}-0.22 \\
(1.50)\end{array}$ & & $\begin{array}{l}-0.21 \\
(1.58)\end{array}$ & $\begin{array}{l}-0.22^{* *} \\
(2.07)\end{array}$ & $\begin{array}{c}-0.22^{* *} \\
(2.23)\end{array}$ & $\begin{array}{l}-0.22^{*} \\
(2.11)\end{array}$ & $\begin{array}{l}-0.19 \\
(1.31)\end{array}$ & $\begin{array}{l}-0.21 \\
(1.43)\end{array}$ & $\begin{array}{l}-0.22 \\
(1.54)\end{array}$ & & & \\
\hline $\begin{array}{l}\text { Distance to Non-Squatted } \\
\text { Area }\end{array}$ & $\begin{array}{l}0.06 \\
(1.14)\end{array}$ & & $\begin{array}{c}0.07 \\
(1.43)\end{array}$ & $\begin{array}{c}0.06 \\
(1.03)\end{array}$ & $\begin{array}{l}0.06 \\
(0.86)\end{array}$ & $\begin{array}{l}0.06 \\
(1.31)\end{array}$ & $\begin{array}{c}0.06 \\
(1.09)\end{array}$ & $\begin{array}{c}0.06 \\
(1.07)\end{array}$ & $\begin{array}{l}0.06 \\
(1.20)\end{array}$ & & & \\
\hline Male & $\begin{array}{c}0.04 \\
(0.42)\end{array}$ & $\begin{array}{l}-0.01 \\
(0.17)\end{array}$ & $\begin{array}{l}-0.01 \\
(0.18)\end{array}$ & $\begin{array}{c}0.04 \\
(0.44)\end{array}$ & $\begin{array}{c}0.04 \\
(0.41)\end{array}$ & $\begin{array}{c}0.04 \\
(0.79)\end{array}$ & $\begin{array}{c}0.04 \\
(0.49)\end{array}$ & $\begin{array}{c}0.04 \\
(0.42)\end{array}$ & $\begin{array}{c}0.05 \\
(0.55)\end{array}$ & & & \\
\hline Child Age & $\begin{array}{l}0.15^{\star * *} \\
(2.76)\end{array}$ & $\begin{array}{l}0.15^{* * *} \\
(2.72)\end{array}$ & $\begin{array}{l}0.15^{* * *} \\
(2.82)\end{array}$ & $\begin{array}{l}0.15^{* * *} \\
(2.93)\end{array}$ & $\begin{array}{l}0.15^{\star * *} \\
(2.95)\end{array}$ & $\begin{array}{l}0.15^{* * *} \\
(5.72)\end{array}$ & $\begin{array}{l}0.15^{\star \star \star} \\
(2.77)\end{array}$ & $\begin{array}{l}0.15^{* * *} \\
(2.78)\end{array}$ & $\begin{array}{l}0.14^{* *} \\
(2.53)\end{array}$ & & & \\
\hline $\begin{array}{l}\text { Age of Original } \\
\text { Squatter }<50\end{array}$ & $\begin{array}{l}-0.08 \\
(0.91)\end{array}$ & & & $\begin{array}{l}-0.08 \\
(0.89)\end{array}$ & $\begin{array}{l}-0.08 \\
(0.88)\end{array}$ & $\begin{array}{l}-0.08 \\
(1.55)\end{array}$ & $\begin{array}{l}-0.08 \\
(0.92)\end{array}$ & $\begin{array}{l}-0.08 \\
(0.83)\end{array}$ & $\begin{array}{l}-0.08 \\
(0.85)\end{array}$ & & & \\
\hline Female Original Squatter & $\begin{array}{l}-0.11 \\
(1.29)\end{array}$ & & & $\begin{array}{l}-0.11 \\
(1.25)\end{array}$ & $\begin{array}{l}-0.11 \\
(1.32)\end{array}$ & $\begin{array}{l}-0.11^{*} \\
(2.02)\end{array}$ & $\begin{array}{l}-0.11 \\
(1.29)\end{array}$ & $\begin{array}{l}-0.11 \\
(1.23)\end{array}$ & $\begin{array}{l}-0.11 \\
(1.31)\end{array}$ & & & \\
\hline $\begin{array}{l}\text { Argentine Original } \\
\text { Squatter }\end{array}$ & $\begin{array}{l}0.49^{*} \\
(1.74)\end{array}$ & & & $\begin{array}{l}0.49^{* *} \\
(2.57)\end{array}$ & $\begin{array}{l}0.49^{* *} \\
(2.59)\end{array}$ & $\begin{array}{l}0.49^{* *} \\
(3.01)\end{array}$ & $\begin{array}{l}0.50^{*} \\
(1.78)\end{array}$ & $\begin{array}{l}0.49^{*} \\
(1.76)\end{array}$ & $\begin{array}{c}0.39 \\
(1.40)\end{array}$ & & & \\
\hline Years of Education of the & 0.04 & & & 0.04 & 0.04 & $0.04^{* *}$ & 0.04 & 0.04 & 0.04 & & & \\
\hline Original Squatter & $(1.53)$ & & & $(1.44)$ & $(1.60)$ & $(2.77)$ & $(1.52)$ & $(1.52)$ & $(1.57)$ & & & \\
\hline Argentine Father of the & $-0.39^{*}$ & & & $-0.39^{* * \star}$ & $-0.39^{* \star *}$ & $-0.39^{* \star *}$ & $-0.40^{*}$ & $-0.39^{*}$ & -0.29 & & & \\
\hline Original Squatter & (1.91) & & & $(4.17)$ & $(4.69)$ & $(4.87)$ & (1.95) & $(1.93)$ & $(1.42)$ & & & \\
\hline Years of Education of & -0.01 & & & -0.01 & -0.01 & -0.01 & 0.00 & 0.00 & -0.01 & & & \\
\hline Original Squatter's Father & $(0.15)$ & & & $(0.19)$ & $(0.18)$ & $(0.19)$ & $(0.12)$ & $(0.12)$ & $(0.14)$ & & & \\
\hline $\begin{array}{l}\text { Argentine Mother of the } \\
\text { Original Squatter }\end{array}$ & $\begin{array}{c}0.22 \\
(1.26)\end{array}$ & & & $\begin{array}{l}0.22^{* *} \\
(2.15)\end{array}$ & $\begin{array}{l}0.22^{*} \\
(1.99)\end{array}$ & $\begin{array}{l}0.22^{* *} \\
(2.60)\end{array}$ & $\begin{array}{l}0.21 \\
(1.2)\end{array}$ & $\begin{array}{c}0.22 \\
(1.26)\end{array}$ & $\begin{array}{c}0.18 \\
(1.04)\end{array}$ & & & \\
\hline $\begin{array}{l}\text { Years of Education of } \\
\text { Original Squatter's }\end{array}$ & $\begin{array}{l}-0.04 \\
(1.04)\end{array}$ & & & $\begin{array}{l}-0.04 \\
(1.03)\end{array}$ & $\begin{array}{l}-0.04 \\
(1.04)\end{array}$ & $\begin{array}{l}-0.04 \\
(1.28)\end{array}$ & $\begin{array}{l}-0.05 \\
(1.11)\end{array}$ & $\begin{array}{l}-0.04 \\
(1.06)\end{array}$ & $\begin{array}{l}-0.04 \\
(1.05)\end{array}$ & & & \\
\hline Constant & $\begin{array}{c}-3.06^{\star * *} \\
(2.75)\end{array}$ & $\begin{array}{c}-2.60^{* *} \\
(2.46)\end{array}$ & $\begin{array}{c}-2.96^{\star \star *} \\
(2.76)\end{array}$ & $\begin{array}{c}-3.06^{* * *} \\
(2.94)\end{array}$ & $\begin{array}{c}-3.06^{* * *} \\
(3.15)\end{array}$ & $\begin{array}{c}-3.06^{* * *} \\
(5.38)\end{array}$ & $\begin{array}{c}-3.12^{\star * *} \\
(2.78)\end{array}$ & $\begin{array}{c}-3.13^{\star * *} \\
(2.78)\end{array}$ & $\begin{array}{c}-2.72^{\star *} \\
(2.43)\end{array}$ & & & \\
\hline F-stat & & & & & & & & & $3.52^{*}$ & & & \\
\hline Observations & 126 & 126 & 126 & 126 & 126 & 126 & 126 & 126 & 126 & 109 & 38 & 81 \\
\hline $\begin{array}{l}\text { Notes: The dependent var } \\
\text { summarized in Column } 5 \\
\text { errors clustered at the hous } \\
\text { intention-to-treat variable } F \\
\text { variable Property Right Off } \\
\text { treatments. The F-stat tes } \\
\text { through (12) present the } \mathrm{m} \\
\text { Appendix Table A.1. Absol }\end{array}$ & $\begin{array}{l}\text { ble is a } \\
\text { Table } 6 \text {. } \\
\text { hold level }\end{array}$ & ed in Colur & $\begin{array}{l}\text { umn (4), } \\
\text { ayed in } \mathrm{C} \\
\text { (8). Colur } \\
\text { perty Rig } \\
\text { propens } \\
\text { rentheses }\end{array}$ & $\begin{array}{l}\text { child has } \\
\text { r child ag } \\
\text { he block I } \\
\text { umn (7). } \\
\text { (9) is the }\end{array}$ & $\begin{array}{l}\text { ished se } \\
\text { nd gende } \\
\text { I in Colur } \\
2 S L S \text { re } \\
\text { ression }\end{array}$ & $\begin{array}{l}\text { ndary sch } \\
\text { Column ( } \\
\text { (4), and a } \\
\text { ession (ins } \\
\text { nmarized }\end{array}$ & $\begin{array}{l}\text { I, and } 0 \mathrm{c} \\
\text { controls } \mathrm{fc} \\
\text { ne former } \\
\text { imenting } \mathrm{t} \\
\text { Column } 6\end{array}$ & $\begin{array}{l}\text { erwise. Th } \\
\text { child age, } \\
\text { /ner level i } \\
\text { treatment } \\
\text { Table 6, y }\end{array}$ & $\begin{array}{l}\text { child is } \\
\text { Id gende } \\
\text { :olumn ( } \\
\text { riable P } \\
\text { ch shows } \\
\text { and late } \\
\text { errors). }\end{array}$ & $\begin{array}{l}\text { Init of o } \\
\text { d parce } \\
\text { te reduc } \\
\text { ty Righ } \\
\text { arately } \\
\text { ment, } \\
\text { control }\end{array}$ & $\begin{array}{l}\text { vation. } \\
\text { racteris } \\
\text { orm reg } \\
\text { the in } \\
\text { fffect of } \\
\text { ctively, } \\
\text { ables ar }\end{array}$ & $\begin{array}{l}\mathrm{mn}(1) \mathrm{i} \\
\text { Standar } \\
\text { on on th } \\
\mathrm{n} \text {-to-trea } \\
\text { and lat } \\
\text { mns (10 } \\
\text { scribed i }\end{array}$ \\
\hline
\end{tabular}




\begin{tabular}{|c|c|c|c|c|c|c|c|c|c|c|c|c|}
\hline \multicolumn{13}{|c|}{ Appendix Table A.15 - POST-SECONDARY EDUCATION (OFFSPRING OF THE HOUSEHOLD HEAD 18-20 YEARS OLD) } \\
\hline & $(1)$ & $(2)$ & $(3)$ & $(4)$ & $(5)$ & (6) & $(7)$ & $(8)$ & (9) & $(10)$ & (11) & (12) \\
\hline Property Right & $\begin{array}{l}0.11^{*} \\
(1.91)\end{array}$ & $\begin{array}{l}0.09^{*} \\
(1.76)\end{array}$ & $\begin{array}{l}0.09^{*} \\
(1.67)\end{array}$ & $\begin{array}{l}0.11^{*} \\
(1.87)\end{array}$ & $\begin{array}{c}0.11 \\
(1.45)\end{array}$ & $\begin{array}{l}0.11^{*} \\
(1.94)\end{array}$ & & $\begin{array}{c}0.10 \\
(1.44)\end{array}$ & & $\begin{array}{l}0.11^{* *} \\
(2.44)\end{array}$ & & \\
\hline Property Right Offer & & & & & & & $\begin{array}{c}0.09 \\
(1.43)\end{array}$ & & & & & \\
\hline Property Right 1989 & & & & & & & & & $\begin{array}{l}0.20^{\star *} \\
(2.23)\end{array}$ & & $\begin{array}{l}0.27^{*} \\
(1.67)\end{array}$ & \\
\hline Property Right 1998 & & & & & & & & & $\begin{array}{c}0.07 \\
(1.18)\end{array}$ & & & $\begin{array}{l}0.08^{*} \\
(1.94)\end{array}$ \\
\hline Parcel Surface & $\begin{array}{l}0.00 \\
(0.87)\end{array}$ & & $\begin{array}{c}0.00 \\
(0.47)\end{array}$ & $\begin{array}{c}0.00 \\
(0.89)\end{array}$ & $\begin{array}{c}0.00 \\
(1.05)\end{array}$ & $\begin{array}{c}0.00 \\
(1.43)\end{array}$ & $\begin{array}{c}0.00 \\
(0.90)\end{array}$ & $\begin{array}{l}0.00 \\
(0.83)\end{array}$ & $\begin{array}{c}0.00 \\
(0.72)\end{array}$ & & & \\
\hline Distance to Creek & $\begin{array}{c}0.05 \\
(1.63)\end{array}$ & & $\begin{array}{l}0.05^{*} \\
(1.70)\end{array}$ & $\begin{array}{c}0.05 \\
(1.62)\end{array}$ & $\begin{array}{c}0.05 \\
(1.60)\end{array}$ & $\begin{array}{l}0.05^{\star *} \\
(2.32)\end{array}$ & $\begin{array}{l}0.05^{\star} \\
(1.67)\end{array}$ & $\begin{array}{c}0.05 \\
(1.59)\end{array}$ & $\begin{array}{c}0.04 \\
(1.20)\end{array}$ & & & \\
\hline Block Corner & $\begin{array}{l}-0.06 \\
(0.61)\end{array}$ & & $\begin{array}{l}-0.06 \\
(0.72)\end{array}$ & $\begin{array}{l}-0.06 \\
(1.02)\end{array}$ & $\begin{array}{l}-0.06 \\
(1.02)\end{array}$ & $\begin{array}{l}-0.06 \\
(1.05)\end{array}$ & $\begin{array}{l}-0.05 \\
(0.47)\end{array}$ & $\begin{array}{l}-0.06 \\
(0.62)\end{array}$ & $\begin{array}{l}-0.06 \\
(0.63)\end{array}$ & & & \\
\hline $\begin{array}{l}\text { Distance to Non-Squatted } \\
\text { Area }\end{array}$ & $\begin{array}{c}0.04 \\
(1.34)\end{array}$ & & $\begin{array}{l}0.05 \\
(1.49)\end{array}$ & $\begin{array}{c}0.04 \\
(1.49)\end{array}$ & $\begin{array}{c}0.04 \\
(1.67)\end{array}$ & $\begin{array}{l}0.04^{*} \\
(1.98)\end{array}$ & $\begin{array}{c}0.05 \\
(1.36)\end{array}$ & $\begin{array}{c}0.05 \\
(1.34)\end{array}$ & $\begin{array}{c}0.05 \\
(1.38)\end{array}$ & & & \\
\hline Male & $\begin{array}{l}0.05 \\
(0.98)\end{array}$ & $\begin{array}{c}0.04 \\
(0.86)\end{array}$ & $\begin{array}{c}0.04 \\
(0.81)\end{array}$ & $\begin{array}{l}0.05 \\
(1.01)\end{array}$ & $\begin{array}{c}0.05 \\
(0.95)\end{array}$ & $\begin{array}{l}0.05^{\star} \\
(1.94)\end{array}$ & $\begin{array}{c}0.06 \\
(1.07)\end{array}$ & $\begin{array}{c}0.05 \\
(0.98)\end{array}$ & $\begin{array}{c}0.06 \\
(1.07)\end{array}$ & & & \\
\hline Child Age & $\begin{array}{c}0.06 \\
(1.65)\end{array}$ & $\begin{array}{l}0.05 \\
(1.38)\end{array}$ & $\begin{array}{c}0.05 \\
(1.45)\end{array}$ & $\begin{array}{l}0.06^{* *} \\
(2.11)\end{array}$ & $\begin{array}{l}0.06^{*} \\
(1.85)\end{array}$ & $\begin{array}{l}0.06^{* *} \\
(2.42)\end{array}$ & $\begin{array}{c}0.06 \\
(1.60)\end{array}$ & $\begin{array}{c}0.06 \\
(1.64)\end{array}$ & $\begin{array}{c}0.05 \\
(1.47)\end{array}$ & & & \\
\hline $\begin{array}{l}\text { Age of Original } \\
\text { Squatter }<50\end{array}$ & $\begin{array}{l}-0.01 \\
(0.10)\end{array}$ & & & $\begin{array}{l}-0.01 \\
(0.09)\end{array}$ & $\begin{array}{l}-0.01 \\
(0.10)\end{array}$ & $\begin{array}{l}-0.01 \\
(0.09)\end{array}$ & $\begin{array}{l}-0.01 \\
(0.24)\end{array}$ & $\begin{array}{l}-0.01 \\
(0.11)\end{array}$ & $\begin{array}{c}0.00 \\
(0.06)\end{array}$ & & & \\
\hline Female Original Squatter & $\begin{array}{l}-0.01 \\
(0.13)\end{array}$ & & & $\begin{array}{l}-0.01 \\
(0.14)\end{array}$ & $\begin{array}{l}-0.01 \\
(0.15)\end{array}$ & $\begin{array}{l}-0.01 \\
(0.15)\end{array}$ & $\begin{array}{l}-0.01 \\
(0.21)\end{array}$ & $\begin{array}{l}-0.01 \\
(0.13)\end{array}$ & $\begin{array}{l}-0.01 \\
(0.13)\end{array}$ & & & \\
\hline $\begin{array}{l}\text { Argentine Original } \\
\text { Squatter }\end{array}$ & $\begin{array}{c}0.10 \\
(0.55)\end{array}$ & & & $\begin{array}{l}0.10 \\
(0.5)\end{array}$ & $\begin{array}{c}0.10 \\
(0.65)\end{array}$ & $\begin{array}{c}0.10 \\
(1.49)\end{array}$ & $\begin{array}{c}0.10 \\
(0.56)\end{array}$ & $\begin{array}{c}0.10 \\
(0.55)\end{array}$ & $\begin{array}{c}0.06 \\
(0.31)\end{array}$ & & & \\
\hline Years of Education of the & -0.01 & & & -0.01 & -0.01 & -0.01 & -0.01 & -0.01 & -0.01 & & & \\
\hline Original Squatter & $(0.56)$ & & & $(0.61)$ & $(0.57)$ & $(1.00)$ & $(0.55)$ & $(0.56)$ & $(0.55)$ & & & \\
\hline Argentine Father of the & $-0.34^{* *}$ & & & $-0.34^{*}$ & $-0.34^{* *}$ & $-0.34^{\star \star \star}$ & $-0.34^{* *}$ & $-0.34^{* *}$ & $-0.30^{* *}$ & & & \\
\hline Original Squatter & $(2.57)$ & & & $(1.93)$ & $(2.13)$ & $(7.87)$ & $(2.57)$ & $(2.56)$ & $(2.18)$ & & & \\
\hline Years of Education of & $0.04^{*}$ & & & 0.04 & 0.04 & 0.04 & $0.04^{*}$ & $0.04^{*}$ & $0.04^{*}$ & & & \\
\hline Original Squatter's Father & $(1.82)$ & & & $(1.48)$ & $(1.24)$ & $(1.33)$ & $(1.80)$ & $(1.81)$ & $(1.84)$ & & & \\
\hline $\begin{array}{l}\text { Argentine Mother of the } \\
\text { Original Squatter }\end{array}$ & $\begin{array}{c}0.14 \\
(1.25)\end{array}$ & & & $\begin{array}{c}0.14 \\
(1.59)\end{array}$ & $\begin{array}{c}0.14 \\
(1.65)\end{array}$ & $\begin{array}{l}0.14^{* *} \\
(2.57)\end{array}$ & $\begin{array}{c}0.13 \\
(1.14)\end{array}$ & $\begin{array}{c}0.14 \\
(1.25)\end{array}$ & $\begin{array}{c}0.13 \\
(1.09)\end{array}$ & & & \\
\hline $\begin{array}{l}\text { Years of Education of } \\
\text { Original Squatter's }\end{array}$ & $\begin{array}{l}-0.03 \\
(1.12)\end{array}$ & & & $\begin{array}{l}-0.03 \\
(1.31)\end{array}$ & $\begin{array}{l}-0.03 \\
(1.25)\end{array}$ & $\begin{array}{l}-0.03^{*} \\
(2.05)\end{array}$ & $\begin{array}{l}-0.03 \\
(1.18)\end{array}$ & $\begin{array}{l}-0.03 \\
(1.11)\end{array}$ & $\begin{array}{l}-0.03 \\
(1.11)\end{array}$ & & & \\
\hline Constant & $\begin{array}{l}-1.28^{*} \\
(1.76)\end{array}$ & $\begin{array}{l}-0.91 \\
(1.34)\end{array}$ & $\begin{array}{l}-1.17^{*} \\
(1.68)\end{array}$ & $\begin{array}{c}-1.28^{* *} \\
(2.21)\end{array}$ & $\begin{array}{l}-1.28^{*} \\
(1.82)\end{array}$ & $\begin{array}{c}-1.28^{* *} \\
(2.42)\end{array}$ & $\begin{array}{l}-1.25^{*} \\
(1.70)\end{array}$ & $\begin{array}{l}-1.27^{*} \\
(1.73)\end{array}$ & $\begin{array}{l}-1.11 \\
(1.52)\end{array}$ & & & \\
\hline F-stat & & & & & & & & & 1.76 & & & \\
\hline Observations & 126 & 126 & 126 & 126 & 126 & 126 & 126 & 126 & 126 & 109 & 38 & 81 \\
\hline $\begin{array}{l}\text { Notes: The dependent var } \\
\text { observation. Column (1) is } \\
\text { characteristics. Standard } \\
\text { reduced-form regression o } \\
\text { Right with the intention-to } \\
\text { separately the effect of ea } \\
\text { treatment, respectively, Co } \\
\text { The control variables are d }\end{array}$ & $\begin{array}{l}\text { e is a d } \\
\text { mmarize } \\
\text { rs cluste } \\
\text { e intent } \\
\text { at variab } \\
\text { and late } \\
\text { ans (10) } \\
\text { ribed in }\end{array}$ & $\begin{array}{l}\text { ough (12 } \\
\text { oendix Te }\end{array}$ & $t$ Offer & ching e & $\begin{array}{l}\text { ly cont } \\
\text { olumn }\end{array}$ & $\begin{array}{l}\text { ndary ec } \\
\text { or child a } \\
\text { t the blc }\end{array}$ & ) is the & $\begin{array}{l}\text { Colum } \\
\text { Imn (4) }\end{array}$ & narized & $\begin{array}{l}\text { otherw } \\
\text { child as } \\
\text { er own } \\
\text { ng the } \\
\text { olumn }\end{array}$ & $\begin{array}{l}\text { e chilc } \\
\text { Id gens } \\
\text { l in Co } \\
\text { ent var } \\
\text { able } 6 \text {, } \\
\text { y treat } \\
\text { bed sta }\end{array}$ & $\begin{array}{l}\text { e unit o } \\
\text { d parce } \\
\text { (6). The } \\
\text { Properts } \\
\text { h shows } \\
\text { and late } \\
\text { d errors) }\end{array}$ \\
\hline
\end{tabular}




\begin{tabular}{|c|c|c|c|c|c|c|c|c|c|c|}
\hline \multicolumn{11}{|c|}{ Appendix Table A.16 - ACCESS TO CREDIT } \\
\hline \multirow[b]{3}{*}{ Property Right } & \multicolumn{2}{|c|}{$\begin{array}{c}\text { Credit Card } \\
\& \text { Bank Account }\end{array}$} & \multicolumn{2}{|c|}{$\begin{array}{c}\text { Non-Mortgage Loan } \\
\text { Received }\end{array}$} & \multicolumn{2}{|c|}{ Informal Credit } & \multicolumn{2}{|c|}{ Grocery Store Credit } & \multicolumn{2}{|c|}{$\begin{array}{l}\text { Mortgage Loan } \\
\text { Received }\end{array}$} \\
\hline & $(1)$ & $(2)$ & $(3)$ & $(4)$ & $(5)$ & $(6)$ & $(7)$ & (8) & $(9)$ & $(10)$ \\
\hline & $\begin{array}{l}-0.01 \\
(0.71)\end{array}$ & & $\begin{array}{c}0.01 \\
(0.19)\end{array}$ & & $\begin{array}{l}-0.06 \\
(1.00)\end{array}$ & & $\begin{array}{c}0.01 \\
(0.16)\end{array}$ & & $\begin{array}{c}0.02 \\
(1.58)\end{array}$ & \\
\hline Property Right 1989 & & $\begin{array}{l}-0.01 \\
(0.41)\end{array}$ & & $\begin{array}{c}0.01 \\
(0.24)\end{array}$ & & $\begin{array}{l}-0.04 \\
(0.50)\end{array}$ & & $\begin{array}{c}0.02 \\
(0.31)\end{array}$ & & $\begin{array}{l}0.04^{* * *} \\
(3.19)\end{array}$ \\
\hline Property Right 1998 & & $\begin{array}{l}-0.02 \\
(0.70)\end{array}$ & & $\begin{array}{l}0.00 \\
(0.11)\end{array}$ & & $\begin{array}{l}-0.07 \\
(1.03)\end{array}$ & & $\begin{array}{l}0.00 \\
(0.01)\end{array}$ & & $\begin{array}{l}0.00 \\
(0.06)\end{array}$ \\
\hline Parcel Surface & $\begin{array}{c}0.00 \\
(1.24)\end{array}$ & $\begin{array}{c}0.00 \\
(1.24)\end{array}$ & $\begin{array}{l}-0.00 \\
(0.50)\end{array}$ & $\begin{array}{l}-0.00 \\
(0.50)\end{array}$ & $\begin{array}{l}-0.00 \\
(1.10)\end{array}$ & $\begin{array}{l}-0.00 \\
(1.11)\end{array}$ & $\begin{array}{l}-0.00 \\
(0.64)\end{array}$ & $\begin{array}{l}-0.00 \\
(0.65)\end{array}$ & $\begin{array}{l}0.00 \\
(0.38)\end{array}$ & $\begin{array}{l}0.00 \\
(0.30)\end{array}$ \\
\hline Distance to Creek & $\begin{array}{l}0.02^{*} \\
(1.95)\end{array}$ & $\begin{array}{l}0.02^{*} \\
(1.82)\end{array}$ & $\begin{array}{l}-0.01 \\
(0.71)\end{array}$ & $\begin{array}{l}-0.01 \\
(0.72)\end{array}$ & $\begin{array}{l}-0.03 \\
(0.98)\end{array}$ & $\begin{array}{l}-0.03 \\
(1.03)\end{array}$ & $\begin{array}{l}-0.01 \\
(0.29)\end{array}$ & $\begin{array}{l}-0.01 \\
(0.36)\end{array}$ & $\begin{array}{c}0.00 \\
(0.34)\end{array}$ & $\begin{array}{l}-0.00 \\
(0.51)\end{array}$ \\
\hline Block Corner & $\begin{array}{l}-0.00 \\
(0.07)\end{array}$ & $\begin{array}{l}-0.00 \\
(0.07)\end{array}$ & $\begin{array}{l}-0.05 \\
(1.06)\end{array}$ & $\begin{array}{l}-0.05 \\
(1.06)\end{array}$ & $\begin{array}{l}-0.13 \\
(1.60)\end{array}$ & $\begin{array}{l}-0.13 \\
(1.59)\end{array}$ & $\begin{array}{c}0.02 \\
(0.30)\end{array}$ & $\begin{array}{c}0.02 \\
(0.30)\end{array}$ & $\begin{array}{c}0.02 \\
(1.37)\end{array}$ & $\begin{array}{c}0.02 \\
(1.41)\end{array}$ \\
\hline Distance to Non-Squatted & 0.00 & 0.00 & -0.03 & -0.03 & -0.00 & -0.00 & -0.03 & -0.03 & -0.00 & -0.00 \\
\hline Area & $(0.19)$ & $(0.19)$ & $(1.62)$ & $(1.62)$ & $(0.07)$ & $(0.06)$ & $(1.22)$ & $(1.22)$ & $(0.44)$ & $(0.43)$ \\
\hline Age of Original Squatter $<50$ & $\begin{array}{c}0.01 \\
(0.53)\end{array}$ & $\begin{array}{c}0.01 \\
(0.53)\end{array}$ & $\begin{array}{c}0.02 \\
(0.66)\end{array}$ & $\begin{array}{c}0.02 \\
(0.65)\end{array}$ & $\begin{array}{l}0.10^{*} \\
(1.65)\end{array}$ & $\begin{array}{c}0.10 \\
(1.63)\end{array}$ & $\begin{array}{c}0.07 \\
(1.24)\end{array}$ & $\begin{array}{c}0.06 \\
(1.22)\end{array}$ & $\begin{array}{l}-0.00 \\
(0.34)\end{array}$ & $\begin{array}{l}-0.00 \\
(0.49)\end{array}$ \\
\hline Female Original Squatter & $\begin{array}{l}-0.00 \\
(0.20)\end{array}$ & $\begin{array}{l}-0.00 \\
(0.21)\end{array}$ & $\begin{array}{l}-0.05 \\
(1.32)\end{array}$ & $\begin{array}{l}-0.05 \\
(1.32)\end{array}$ & $\begin{array}{c}0.02 \\
(0.28)\end{array}$ & $\begin{array}{c}0.02 \\
(0.28)\end{array}$ & $\begin{array}{l}-0.08 \\
(1.44)\end{array}$ & $\begin{array}{l}-0.08 \\
(1.44)\end{array}$ & $\begin{array}{c}0.01 \\
(0.52)\end{array}$ & $\begin{array}{l}0.00 \\
(0.51)\end{array}$ \\
\hline Argentine Original Squatter & $\begin{array}{l}-0.00 \\
(0.09)\end{array}$ & $\begin{array}{l}-0.01 \\
(0.10)\end{array}$ & $\begin{array}{l}-0.01 \\
(0.17)\end{array}$ & $\begin{array}{l}-0.02 \\
(0.17)\end{array}$ & $\begin{array}{c}0.01 \\
(0.04)\end{array}$ & $\begin{array}{l}0.00 \\
(0.02)\end{array}$ & $\begin{array}{l}0.22^{*} \\
(1.71)\end{array}$ & $\begin{array}{l}0.22^{*} \\
(1.69)\end{array}$ & $\begin{array}{l}0.01 \\
(0.31)\end{array}$ & $\begin{array}{l}0.00 \\
(0.16)\end{array}$ \\
\hline $\begin{array}{l}\text { Years of Education of the } \\
\text { Original Squatter }\end{array}$ & $\begin{array}{c}0.01 \\
(1.34)\end{array}$ & $\begin{array}{c}0.01 \\
(1.33)\end{array}$ & $\begin{array}{l}-0.00 \\
(0.25)\end{array}$ & $\begin{array}{l}-0.00 \\
(0.25)\end{array}$ & $\begin{array}{l}-0.02 \\
(1.06)\end{array}$ & $\begin{array}{l}-0.02 \\
(1.07)\end{array}$ & $\begin{array}{l}-0.00 \\
(0.33)\end{array}$ & $\begin{array}{l}-0.01 \\
(0.34)\end{array}$ & $\begin{array}{c}0.00 \\
(0.70)\end{array}$ & $\begin{array}{l}0.00 \\
(0.62)\end{array}$ \\
\hline Argentine Father of the & -0.02 & -0.02 & -0.07 & -0.07 & 0.15 & 0.15 & -0.02 & -0.02 & -0.00 & 0.00 \\
\hline Original Squatter & $(0.60)$ & $(0.59)$ & $(1.03)$ & $(1.03)$ & $(1.27)$ & $(1.28)$ & $(0.17)$ & $(0.16)$ & $(0.01)$ & $(0.10)$ \\
\hline Years of Education of & $0.03^{* * *}$ & $0.03^{* \star *}$ & 0.00 & 0.00 & 0.03 & 0.03 & -0.02 & -0.02 & 0.01 & $0.01^{*}$ \\
\hline Original Squatter's Father & $(2.82)$ & $(2.82)$ & $(0.14)$ & $(0.14)$ & (1.19) & (1.19) & $(0.72)$ & $(0.72)$ & $(1.65)$ & $(1.72)$ \\
\hline Argentine Mother of the & 0.03 & 0.03 & 0.10 & 0.10 & -0.02 & -0.02 & -0.00 & -0.00 & 0.00 & 0.00 \\
\hline Original Squatter & $(0.77)$ & $(0.76)$ & $(1.34)$ & $(1.33)$ & $(0.17)$ & $(0.18)$ & $(0.03)$ & $(0.04)$ & $(0.24)$ & $(0.11)$ \\
\hline Years of Education of & $-0.02^{*}$ & $-0.02^{*}$ & $0.04^{* *}$ & $0.04^{* *}$ & 0.04 & 0.04 & 0.01 & 0.01 & $-0.01^{*}$ & $-0.01^{*}$ \\
\hline Original Squatter's Mother & $(1.75)$ & $(1.75)$ & $(2.09)$ & $(2.08)$ & $(1.31)$ & $(1.29)$ & $(0.53)$ & $(0.52)$ & $(1.68)$ & $(1.79)$ \\
\hline Constant & $\begin{array}{l}-0.14^{*} \\
(1.77)\end{array}$ & $\begin{array}{l}-0.14^{*} \\
(1.72)\end{array}$ & $\begin{array}{c}0.06 \\
(0.40)\end{array}$ & $\begin{array}{c}0.06 \\
(0.42)\end{array}$ & $\begin{array}{c}0.23 \\
(1.03)\end{array}$ & $\begin{array}{c}0.24 \\
(1.07)\end{array}$ & $\begin{array}{c}0.25 \\
(1.24)\end{array}$ & $\begin{array}{c}0.26 \\
(1.26)\end{array}$ & $\begin{array}{l}-0.03 \\
(0.82)\end{array}$ & $\begin{array}{l}-0.01 \\
(0.35)\end{array}$ \\
\hline F-stat & & 0.02 & & 0.02 & & 0.10 & & 0.08 & & $8.61^{* \star *}$ \\
\hline Observations & 312 & 312 & 312 & 312 & 302 & 302 & 312 & 312 & 312 & 312 \\
\hline $\begin{array}{l}\text { Notes: Credit Card \& Bank } \\
\text { Received and Mortgage Loa } \\
\text { non-mortgage credit or form } \\
\text { credit from relatives, colleag } \\
\text { usually receives on trust cre } \\
\text { Table } 7 . \text { The F-stat test the } \\
\text { t statistics are in parenthese }\end{array}$ & ses: Prop & Right 19 & 50\%.*** & usehold & control & ion. Cc & $\begin{array}{l}\text { (1), (3) } \\
\text { cribed in }\end{array}$ & endix Ta & $\begin{array}{l}\text { e. Non-1 } \\
\text { or coop }\end{array}$ & $\begin{array}{l}\text { age Lo } \\
\text { ve, form }\end{array}$ \\
\hline
\end{tabular}




\begin{tabular}{|c|c|c|c|c|c|c|c|c|c|c|}
\hline \multicolumn{11}{|c|}{ Appendix Table A.17 - LABOR MARKET } \\
\hline \multirow[b]{3}{*}{ Property Right } & \multicolumn{2}{|c|}{$\begin{array}{l}\text { Household Head } \\
\text { Income }\end{array}$} & \multicolumn{2}{|c|}{$\begin{array}{l}\text { Total Household } \\
\text { Income }\end{array}$} & \multicolumn{2}{|c|}{$\begin{array}{l}\text { Total Household } \\
\text { Income per Capita }\end{array}$} & \multicolumn{2}{|c|}{$\begin{array}{l}\text { Total Household } \\
\text { Income per Adult }\end{array}$} & \multicolumn{2}{|c|}{$\begin{array}{c}\text { Employed Household } \\
\text { Head }\end{array}$} \\
\hline & $(1)$ & $(2)$ & (3) & (4) & $(5)$ & (6) & $(7)$ & $(8)$ & (9) & $(10)$ \\
\hline & $\begin{array}{l}-27.35 \\
(1.10)\end{array}$ & & $\begin{array}{l}-43.56 \\
(1.27)\end{array}$ & & $\begin{array}{l}1.04 \\
(0.13)\end{array}$ & & $\begin{array}{l}-4.45 \\
(0.38)\end{array}$ & & $\begin{array}{l}0.03 \\
(0.63)\end{array}$ & \\
\hline Property Right 1989 & & $\begin{array}{l}-22.07 \\
(0.63)\end{array}$ & & $\begin{array}{l}-32.71 \\
(0.69)\end{array}$ & & $\begin{array}{c}8.91 \\
(0.82)\end{array}$ & & $\begin{array}{l}-6.89 \\
(0.43)\end{array}$ & & $\begin{array}{l}0.05 \\
(0.64)\end{array}$ \\
\hline Property Right 1998 & & $\begin{array}{l}-30.34 \\
(1.06)\end{array}$ & & $\begin{array}{l}-49.85 \\
(1.27)\end{array}$ & & $\begin{array}{l}-3.52 \\
(0.39)\end{array}$ & & $\begin{array}{l}-3.04 \\
(0.23)\end{array}$ & & $\begin{array}{l}0.02 \\
(0.43)\end{array}$ \\
\hline Parcel Surface & $\begin{array}{l}-0.10 \\
(0.62)\end{array}$ & $\begin{array}{l}-0.10 \\
(0.62)\end{array}$ & $\begin{array}{c}0.01 \\
(0.05)\end{array}$ & $\begin{array}{l}0.01 \\
(0.04)\end{array}$ & $\begin{array}{l}-0.01 \\
(0.21)\end{array}$ & $\begin{array}{l}-0.01 \\
(0.22)\end{array}$ & $\begin{array}{l}0.01 \\
(0.10)\end{array}$ & $\begin{array}{l}0.01 \\
(0.10)\end{array}$ & $\begin{array}{l}-0.00 \\
(0.94)\end{array}$ & $\begin{array}{l}-0.00 \\
(0.94)\end{array}$ \\
\hline Distance to Creek & $\begin{array}{l}8.25 \\
(0.63)\end{array}$ & $\begin{array}{l}7.45 \\
(0.55)\end{array}$ & $\begin{array}{l}13.69 \\
(0.76)\end{array}$ & $\begin{array}{l}11.98 \\
(0.64)\end{array}$ & $\begin{array}{l}2.83 \\
(0.69)\end{array}$ & $\begin{array}{c}1.59 \\
(0.37)\end{array}$ & $\begin{array}{c}0.66 \\
(0.11)\end{array}$ & $\begin{array}{l}1.05 \\
(0.17)\end{array}$ & $\begin{array}{l}-0.01 \\
(0.32)\end{array}$ & $\begin{array}{l}-0.01 \\
(0.38)\end{array}$ \\
\hline Block Corner & $\begin{array}{l}29.72 \\
(0.80)\end{array}$ & $\begin{array}{l}30.02 \\
(0.80)\end{array}$ & $\begin{array}{l}32.25 \\
(0.62)\end{array}$ & $\begin{array}{l}32.54 \\
(0.63)\end{array}$ & $\begin{array}{l}12.97 \\
(1.10)\end{array}$ & $\begin{array}{l}13.18 \\
(1.11)\end{array}$ & $\begin{array}{l}14.00 \\
(0.80)\end{array}$ & $\begin{array}{l}13.93 \\
(0.80)\end{array}$ & $\begin{array}{l}-0.11 \\
(1.46)\end{array}$ & $\begin{array}{l}-0.11 \\
(1.45)\end{array}$ \\
\hline Distance to Non-Squatted & 0.59 & 0.73 & 10.95 & 11.20 & 0.72 & 0.91 & 1.29 & 1.23 & $0.06^{\star \star}$ & $0.06^{* *}$ \\
\hline Area & $(0.05)$ & $(0.06)$ & $(0.64)$ & $(0.66)$ & $(0.19)$ & $(0.23)$ & $(0.22)$ & $(0.21)$ & $(2.24)$ & $(2.23)$ \\
\hline Age of Original Squatter $<50$ & $\begin{array}{l}17.67 \\
(0.70)\end{array}$ & $\begin{array}{l}17.50 \\
(0.70)\end{array}$ & $\begin{array}{l}-17.51 \\
(0.51)\end{array}$ & $\begin{array}{l}-18.21 \\
(0.52)\end{array}$ & $\begin{array}{l}-12.50 \\
(1.58)\end{array}$ & $\begin{array}{l}-13.01 \\
(1.64)\end{array}$ & $\begin{array}{c}8.30 \\
(0.71)\end{array}$ & $\begin{array}{c}8.46 \\
(0.72)\end{array}$ & $\begin{array}{l}0.09^{\star} \\
(1.68)\end{array}$ & $\begin{array}{l}0.08^{\star} \\
(1.65)\end{array}$ \\
\hline Female Original Squatter & $\begin{array}{c}-50.45^{\star *} \\
(2.01)\end{array}$ & $\begin{array}{c}-50.21^{* *} \\
(1.99)\end{array}$ & $\begin{array}{c}-62.87^{*} \\
(1.80)\end{array}$ & $\begin{array}{c}-62.54^{*} \\
(1.78)\end{array}$ & $\begin{array}{l}-8.49 \\
(1.06)\end{array}$ & $\begin{array}{l}-8.26 \\
(1.03)\end{array}$ & $\begin{array}{l}-14.47 \\
(1.22)\end{array}$ & $\begin{array}{r}-14.54 \\
(1.23)\end{array}$ & $\begin{array}{l}-0.10^{*} \\
(1.96)\end{array}$ & $\begin{array}{l}-0.10^{*} \\
(1.96)\end{array}$ \\
\hline Argentine Original Squatter & $\begin{array}{r}-15.10 \\
(0.25)\end{array}$ & $\begin{array}{r}-15.67 \\
(0.26)\end{array}$ & $\begin{array}{c}18.43 \\
(0.22)\end{array}$ & $\begin{array}{l}17.40 \\
(0.21)\end{array}$ & $\begin{array}{l}29.03 \\
(1.51)\end{array}$ & $\begin{array}{l}28.28 \\
(1.47)\end{array}$ & $\begin{array}{l}39.15 \\
(1.38)\end{array}$ & $\begin{array}{l}39.38 \\
(1.39)\end{array}$ & $\begin{array}{l}-0.05 \\
(0.37)\end{array}$ & $\begin{array}{l}-0.05 \\
(0.38)\end{array}$ \\
\hline Years of Education of the & 3.20 & 3.14 & 9.52 & 9.44 & $5.29^{* *}$ & $5.23^{* *}$ & 4.13 & 4.15 & 0.01 & 0.01 \\
\hline Original Squatter & $(0.46)$ & $(0.45)$ & $(0.99)$ & $(0.98)$ & $(2.40)$ & $(2.37)$ & $(1.27)$ & $(1.27)$ & $(0.59)$ & $(0.58)$ \\
\hline Argentine Father of the & -20.68 & -20.47 & -9.10 & -8.62 & -20.63 & -20.28 & $-40.66^{\star}$ & $-40.77^{*}$ & 0.07 & 0.07 \\
\hline Original Squatter & $(0.44)$ & $(0.44)$ & $(0.14)$ & $(0.13)$ & $(1.38)$ & $(1.36)$ & $(1.85)$ & $(1.85)$ & $(0.67)$ & $(0.68)$ \\
\hline Years of Education of & 4.36 & 4.40 & 23.45 & 23.51 & 2.88 & 2.93 & -1.35 & -1.36 & 0.01 & 0.01 \\
\hline Original Squatter's Father & $(0.41)$ & $(0.41)$ & $(1.45)$ & $(1.45)$ & $(0.78)$ & $(0.79)$ & $(0.25)$ & $(0.25)$ & $(0.48)$ & $(0.49)$ \\
\hline Argentine Mother of the & 20.29 & 19.78 & -69.84 & -71.01 & -3.35 & -4.20 & 3.87 & 4.14 & 0.00 & 0.00 \\
\hline Original Squatter & $(0.44)$ & $(0.43)$ & $(1.09)$ & $(1.10)$ & $(0.23)$ & $(0.29)$ & $(0.18)$ & $(0.19)$ & $(0.05)$ & $(0.03)$ \\
\hline Years of Education of & -10.69 & -10.80 & -2.67 & -2.88 & -4.09 & -4.24 & -2.35 & -2.31 & -0.01 & -0.01 \\
\hline Original Squatter's Mother & $(0.92)$ & $(0.93)$ & $(0.16)$ & $(0.17)$ & $(1.09)$ & $(1.13)$ & $(0.42)$ & $(0.41)$ & $(0.40)$ & $(0.41)$ \\
\hline Constant & $\begin{array}{c}313.47^{* * *} \\
(3.34)\end{array}$ & $\begin{array}{c}316.34^{* * *} \\
(3.33)\end{array}$ & $\begin{array}{c}246.89^{*} \\
(1.88)\end{array}$ & $\begin{array}{c}253.17^{*} \\
(1.90)\end{array}$ & $\begin{array}{l}44.44 \\
(1.48)\end{array}$ & $\begin{array}{l}48.99 \\
(1.61)\end{array}$ & $\begin{array}{c}97.59^{* *} \\
(2.20)\end{array}$ & $\begin{array}{c}96.18^{* *} \\
(2.14)\end{array}$ & $\begin{array}{c}0.67^{* * *} \\
(3.41)\end{array}$ & $\begin{array}{c}0.68^{* * *} \\
(3.41)\end{array}$ \\
\hline F-stat & & 0.05 & & 0.11 & & 1.10 & & 0.05 & & 0.07 \\
\hline Observations & 251 & 251 & 255 & 255 & 255 & 255 & 255 & 255 & 310 & 310 \\
\hline $\begin{array}{l}\text { Notes: Household Head Inco } \\
\text { household members in the } \\
\text { Household Income per Adult } \\
\text { Argentine pesos. Employed } \\
\text { household is the unit of obse } \\
\text { Right } 1998 \text {. The control vari } \\
\text { significant at } 1 \% \text {. }\end{array}$ & $\begin{array}{l}\text { Head is a } \\
\text { olumns (1), } \\
\text { described i }\end{array}$ & $\begin{array}{l}\text { Immy varial } \\
\text { 3), (5), (7), } \\
\text { Appendix T }\end{array}$ & e A.1. Ab & $\begin{array}{l}\text { if the ho } \\
\text { marized } \\
\text { ite values }\end{array}$ & $\begin{array}{l}\text { ble } 8 . T \\
\text { statistic }\end{array}$ & $\begin{array}{l}\text { emplo } \\
\text { stat tes } \\
\text { in par }\end{array}$ & ses. * Si & $\begin{array}{l}\text { income } \\
\text { re the s } \\
\text { es: Pro } \\
\text { ant at } 1\end{array}$ & $\begin{array}{l}\text { Right } 1 \\
* * \text { signifi }\end{array}$ & $\begin{array}{l}\text { by all the } \\
\text { ers. Tota } \\
\text { asured in } \\
\text { wise. The } \\
=\text { Property } \\
\text { at } 5 \% \text {; *** }\end{array}$ \\
\hline
\end{tabular}

